\title{
Excavation of a promontory fort and a palisaded homestead at Lower Greenyards, Bannockburn, Stirling, 1982-5
}

James S Rideout*

from text and reports by G Barclay, L Barnetson, J Birnie, A Clarke, A Clydesdale, A Fairweather, B Finlayson, A Gibson, D Hall, J Henderson, D Jordan, J Lee, R McCullagh, V J McLellan, A MacSween, J S Rideout, C Russell-White, J Shiels \& P N Tavener

\begin{abstract}
Excavations undertaken in 1982, 1984 and 1985 on cropmark sites of a promontory fort and nearby palisaded homestead revealed structural remains mainly of the Iron Age and evidence of occupation or other activity from the Mesolithic to the present day. The palisaded homestead was paralleled by a similar homestead phase of the occupation of the promontory, later replaced by a fort with three periods of defence construction. The project was organized and funded by Historic Scotland (former $S D D / H M B)$.
\end{abstract}

\section{INTRODUCTION}

Between September 1982 and June 1985, three seasons of excavation were undertaken by the then Central Excavation Unit (Historic Buildings and Monuments) on cropmark sites at Bannockburn, Stirling. The sites, identified before excavation as a promontory fort, a palisaded homestead, and two pit alignments, lay immediately to the east of the village of Bannockburn (sites centred at NGR: NS 816903 , NS 817903 , and NS 816901 respectively). The fort and the homestead both lay between the B9124 Bannockburn to Cowie road, to the south, and the Edinburgh to Stirling railway, to the north. The pit alignments lay immediately to the south of the B9124 (illus 1).

The homestead and the eastern part of the pit alignments came under threat from the proposed construction of the new Stirling Eastern Distributor Road. The land between the new road and Bannockburn was scheduled for housing development, threatening the fort and the rest of the pit alignments. A second palisaded homestead, to the east of the first, was not threatened.

\section{GEOLOGY, GEOMORPHOLOGY, AND SOILS}

\section{David Jordan}

The superficial geology underlying the fort and pit alignments is banded silts, sands and gravels with indurated (hardened) upper strata, showing the typical structure of glacial outwash deposits. This 


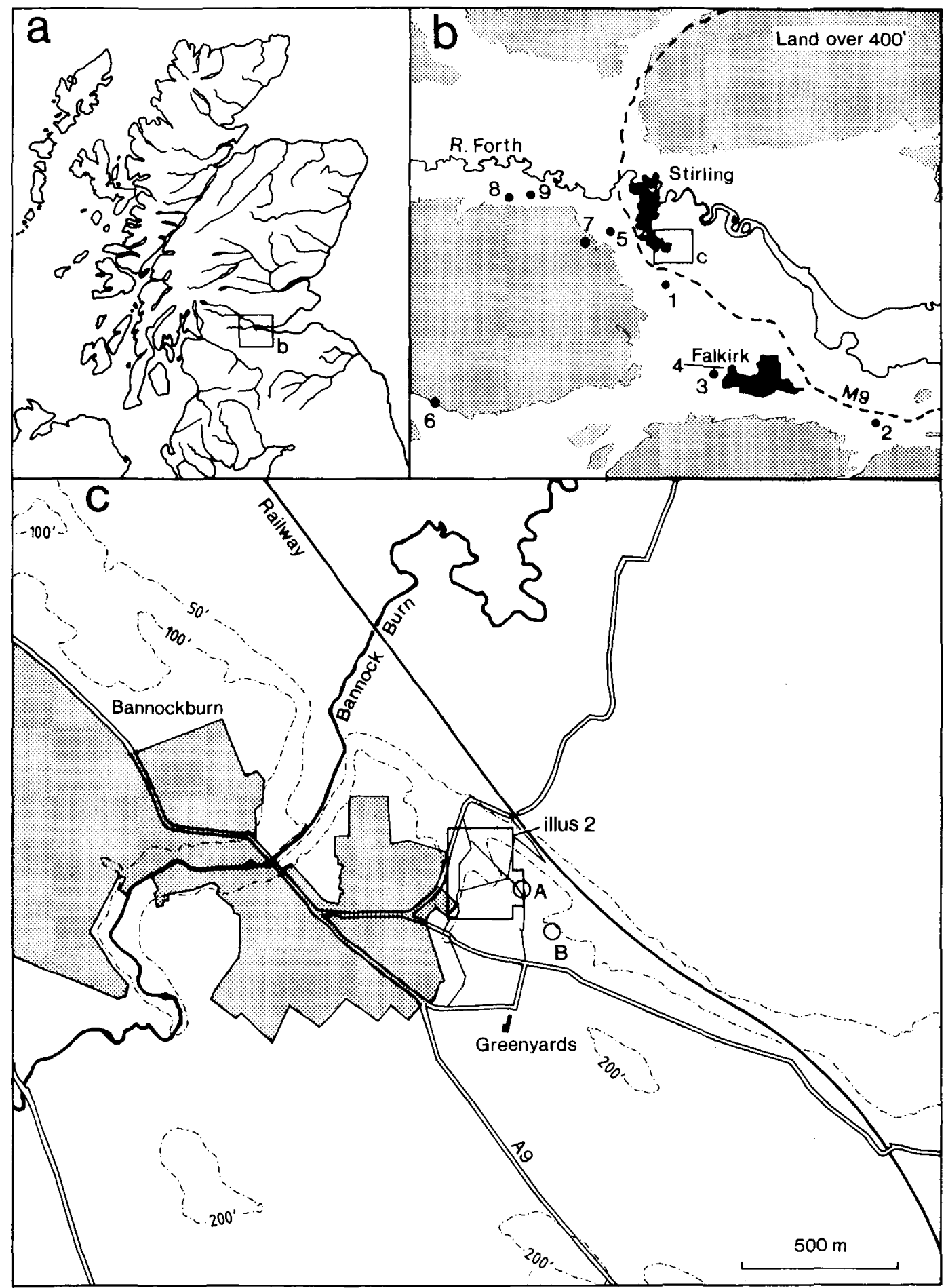

ILlus 1 Lower Greenyards location : sites on map b - 1 West Plean, 2 Myrehead, 3 Wester Carmuirs, 4 Camelon, 5 Gillies Hill, 6 Meikle Reive, 7 Castlehill Wood, 8 Leckie, 9 Keir Hill, Gargunnock; on map c - A Homestead 1, B - unexcavated homestead (Based on the Ordnance Survey map (C) Crown Copyright) 
induration impedes drainage only in the lowest soil horizons and where the strata are of silts and fine sands. Elsewhere soil drainage is good due to the coarseness of the deposits and their high degree of sorting. This, combined with the quartz richness of the particles has had a particular influence upon the soil formation, inducing light, easily worked soils which tend to acidity. The parent material underlying the pit alignments shows the full range of textures from silts to coarse gravels, those underlying the fort are sandier. This may relate to the till surface which dips northwards and therefore deepens beneath the waterlaid deposits.

The fort and pit alignments both lie on the first terrace above the Forth valley at an altitude of between $35 \mathrm{~m}$ and $38 \mathrm{~m}$ OD, also known as the Main Perth Shoreline, which has been cut by incised drainage channels from the south. These now define the spur on which the fort is found and the streams running through them drain the sites. The channels have widened since the sites were formed. Colluvial deposits now overlie the archaeological stratigraphy found on the lower slopes around the fort and the large ditches which form the southern limit of the site have been truncated by lateral erosion, much of which may be the result of ploughing. As Birnie notes (below) the valley draining the west of the sites is occupied by an active stream, while that to the east of the promontory on which the fort is found is poorly drained and peat has grown within it.

The southern end of the area of impeded drainage to the east of the fort is now under cultivation and a lynchet of approximately $1 \mathrm{~m}$ in height which divides the cultivated from the uncultivated areas gives an indication of the considerable volume of the site which has been eroded as a result of cultivation.

The area of the fort and pit alignments is mapped (Soil Survey of Scotland 1968) as being found in two different soil types although, in practice the differences are small. The pit alignments are mapped as lying on soils of the Kennet series, these being 'imperfectly drained', brown forest soils formed on tills derived from Carboniferous sediments, dominantly sandstones with some shales, coals and limestones, with partially water-sorted upper layers. The fort is mapped as lying on soils of the Darvel series, these being freely drained, brown forest soils formed on fluvioglacial sands and gravels derived from Carboniferous igneous and sedimentary rocks with some Lower Old Red Sandstone and Highland Schist erratics.

\section{VEGETATION}

\section{James S Rideout}

The Land Capability for Agriculture map for south-east Scotland shows that all the land in the area is Class 3.2 (1982, Sheet 7). This land is capable of producing high yields of cereals and root crops in rotation with grass leys. At the time of the CEU excavations most of the area around the sites (the field containing the south defences of the fort, the fields to the east of the fort, and the field containing the pit alignments) was under intense arable cultivation, mostly cereals and root crops. The nose of the promontory occupied by the fort was under well-developed meadow vegetation with the west and north flanks colonized by hawthorn (Crataegus monogyna), broom (Sarothamnus scoparius), and bramble (Rubus fruticosus agg). A lynchet running around the lower flanks to the west, north, and east was probably the result of pre-First World War arable cultivation. The lynchet roughly defined a boundary between the meadow/scrub vegetation of the nose of the promontory and the bog vegetation to the north and in the gully to the east. Mature trees lined the burn to the west of the site. The end of the promontory to the west of the boggy gully, and to the north of Homestead 1, was grass pasture with mature trees, mostly alder (Alnus glutinosa) and hawthorn, and scrub on its flanks. 


\section{ARCHAEOLOGICAL BACKGROUND}

\section{Gordon Barclay}

Prior to the mid-1970s only one site was known, lying on a defended promontory immediately to the east of the edge of Bannockburn (NGR: NS 816 904). It was described by the Royal Commission on the Ancient and Historical Monuments of Scotland in their Inventory of Stirlingshire (RCAHMS 1963, 420, no 493). They noted two cropmark ditches on National Survey photographs 540/RAF/ 1645, F22, 0274-5, taken in June 1955, just two months before the site was visited by fieldworkers from the RCAHMS. A further ditch appears to the south, interpreted as a natural feature in 1955. In July 1955 a more informative vertical photograph was taken (540/RAF 1691, F21, 0069 - this does not seem to have been seen by RCAHMS).

In 1974 the Stirling Field and Archaeological Society (SFAS) carried out an excavation on that part of the site under arable cultivation, that is the southern portion of the promontory, where the two lines of defence were believed to lie. The excavation took the form of a trench, $65 \mathrm{~m} \mathrm{long}, 1 \mathrm{~m}$ wide, cut southwards from the fence dividing the arable and pasture, over the expected lines of defence. In all, five ditches and two possible palisade trenches were found, the northernmost being only a few metres from the fence. The excavation was reported in Discovery and Excavation in Scotland (SFAS 1974, 65).

In 1976 the Cambridge University Committee for Aerial Photography took a valuable series of photographs, followed by a further sortie in 1977, when RCAHMS also photographed the area. In addition to the promontory fort, where the five ditches and two of the palisades showed clearly, two palisaded enclosures and the pit alignments were discovered. The palisaded enclosures were visible on the vertical aerial photograph; the pit alignment was not. The clearest of the two enclosures took the form of a subcircular paddock defined by a narrow ditch. Roughly centrally lay a circular narrow-ditched house (Maxwell 1982, 50-1). The other enclosure appeared to be badly eroded on the modern oblique coverage, but shows better on the 1955 vertical where it seems to be roughly similar to the other palisade.

\section{EXCAVATION AND METHODOLOGY}

As the scale of the remains of the largest threatened site, the promontory fort, was unknown it was decided that a large-scale trial excavation would be mounted; as the time available for excavation immediately before the building of the houses would probably be short, it was hoped that this first season would do $30-50 \%$ of the work necessary on the site. A 10 -week season of excavation was mounted on the nose of the promontory to investigate the whole of its flat top and to examine any defences on its flanks. A trench was also planned in the bog to the east, to obtain a peat column, to look for any submerged structural elements and to search for organic artefacts (illus 2). A magnetometer survey was mounted on the arable area during the excavation to try to add to the information available from aerial photography (report in archive). This was only a limited success - it suggested that the visible cropmark ditches might extend further to the east than the photographs suggested, perhaps influencing the interpretation of the position of the entrance. With only the air photograph evidence to hand, and that not relevant to the accessible area, work began on 16 August 1982 under the direction of $\mathrm{G}$ Barclay. The second season on the fort, directed by $\mathrm{J}$ Rideout (who had been deputy director of the first season), was mounted in 1985 when the threatened developments seemed imminent. That part of the palisaded homestead (Homestead 1) threatened by the road was excavated by $\mathrm{P} N$ Tavener in October and November 1984. Excavation of the pit alignments started in the 


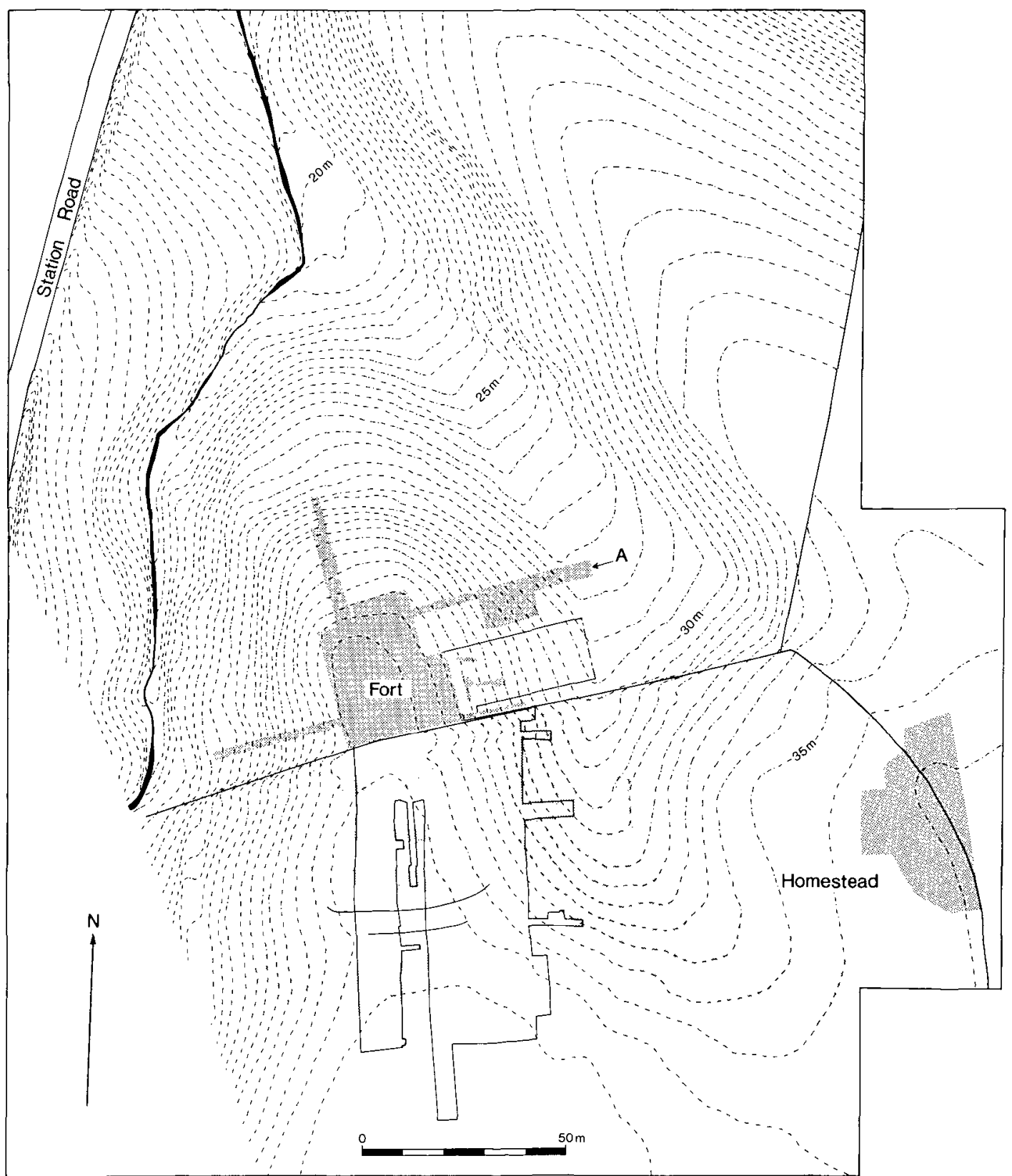

IlLus 2 Plan of the area around the Lower Greenyards fort and homestead; the heavier stipple on the fort site shows the 1982 trenches; the 1985 trenches are in outline; the lighter stipple is a plot of the cropmarks on the air photo; A - location of pollen monolith 
same season and was completed during the second fort season in 1985. The results of the excavation of the pit alignments are published separately (Tavener \& Rideout forthcoming).

\section{HOMESTEAD 1}

\section{P N Tavener with J S Rideout}

\section{DESCRIPTION AND INTERPRETATION}

Permission to excavate even a small area beyond the edge of the proposed road line was not forthcoming. The entire available area of the enclosure was stripped, as well as a limited area outside (illus 3). Overall, the area measured a maximum of $41.5 \mathrm{~m}$ by $21.5 \mathrm{~m}$. Two main features - a palisade trench and a round house, comprising wall grooves, internal postring and external post-ring - were investigated. Medieval and later activity was also noted. The palisaded enclosure and the house contained by it had been crossed by a modern field boundary.

\section{Medieval and modern activity}

The field boundary, a hedgerow partly replaced by a fence, crossed the enclosure passing over the south-west side of the house. Modern disturbance consisted of a ditch and recent tree-removal disturbance. A sherd of post-medieval pottery $(60 / 13)$ was recovered from the modern A-horizon and part of a possible spindle whorl (60/9) and a sherd of post-medieval pottery $(60 / 10)$ were found in the modern B-horizon. Over much of the area an old topsoil associated with rig and furrow cultivation lay beneath the modern ploughsoil. Parts of six furrows, running north/south across the trench belonging to this cultivation system were found. A linear trail of medium-sized stones, $13 \mathrm{~m}$ long, ran parallel to the furrows at the north end of the trench (illus 4). It is possible that this was a field or plot marker. The buried medieval topsoil produced post-medieval pottery $(60 / 3,60 / 4$, $60 / 8,60 / 11$ ) as well as a sherd of white-glazed pottery, a fragment of brick or burnt daub and a fragment of pipe-stem (not described in the finds catalogues).

The heavily robbed remains of two stone-built walls, the eastern $3 \mathrm{~m}$ north/south and $0.5 \mathrm{~m}$ wide, the western $2.5 \mathrm{~m}$ east/west, forming a corner point of a building, were found $0.2 \mathrm{~m}$ below ground level at the point where the palisade passed under the hedgerow in the south-east corner of the trench (illus 5). Beside the building was a layer containing cinders which produced an iron nail (60/1).The walls overlay the soil associated with rig and furrow cultivation. At this point, it had been hoped that stratigraphy relating to the palisade would be better preserved as the result of its being untouched by recent ploughing. It was found, however, that all stratigraphy above the subsoil relating to the palisade had been truncated. An iron nail (60/7) was found on the subsoil surface.

The remains of the angle of walling on the edge of the excavated area must represent a building of unknown size and function. Its location, however, is only $70 \mathrm{~m} \mathrm{NNW}$ of the ruins of a farm, Wester Greenyards, marked on the 1st edition of the Ordnance Survey, although no building is shown at this spot (Stirling Sheet XVII, 1865, surveyed 1860). Wester Greenyards was recorded by Pont when he surveyed Scotland at the end of the 16 th century. It would be reasonable, therefore, to link the building to this period.

The traces of medieval or post-medieval cultivation are similar to that recorded in the fort area although the alignment is different (east/west). The presence of the rig-and-furrow, and the amount of post-medieval pottery in the soil overlying the homestead and the fort, serves to confirm the quality of the land and its continued use for arable cultivation.

\section{The palisade}

The palisade was nearly perfectly circular, about $46 \mathrm{~m}$ in diameter, and enclosed an area of $0.16 \mathrm{ha}$, of which the house occupied $350 \mathrm{sq} \mathrm{m}$. The palisade had been set in a continuous trench $0.5 \mathrm{~m}$ to $0.6 \mathrm{~m}$ wide at the surface, tapering to $0.3 \mathrm{~m}$ to $0.4 \mathrm{~m}$ wide at its base. It varied between $0.9 \mathrm{~m}$ deep on the north side to $0.6 \mathrm{~m}$ 


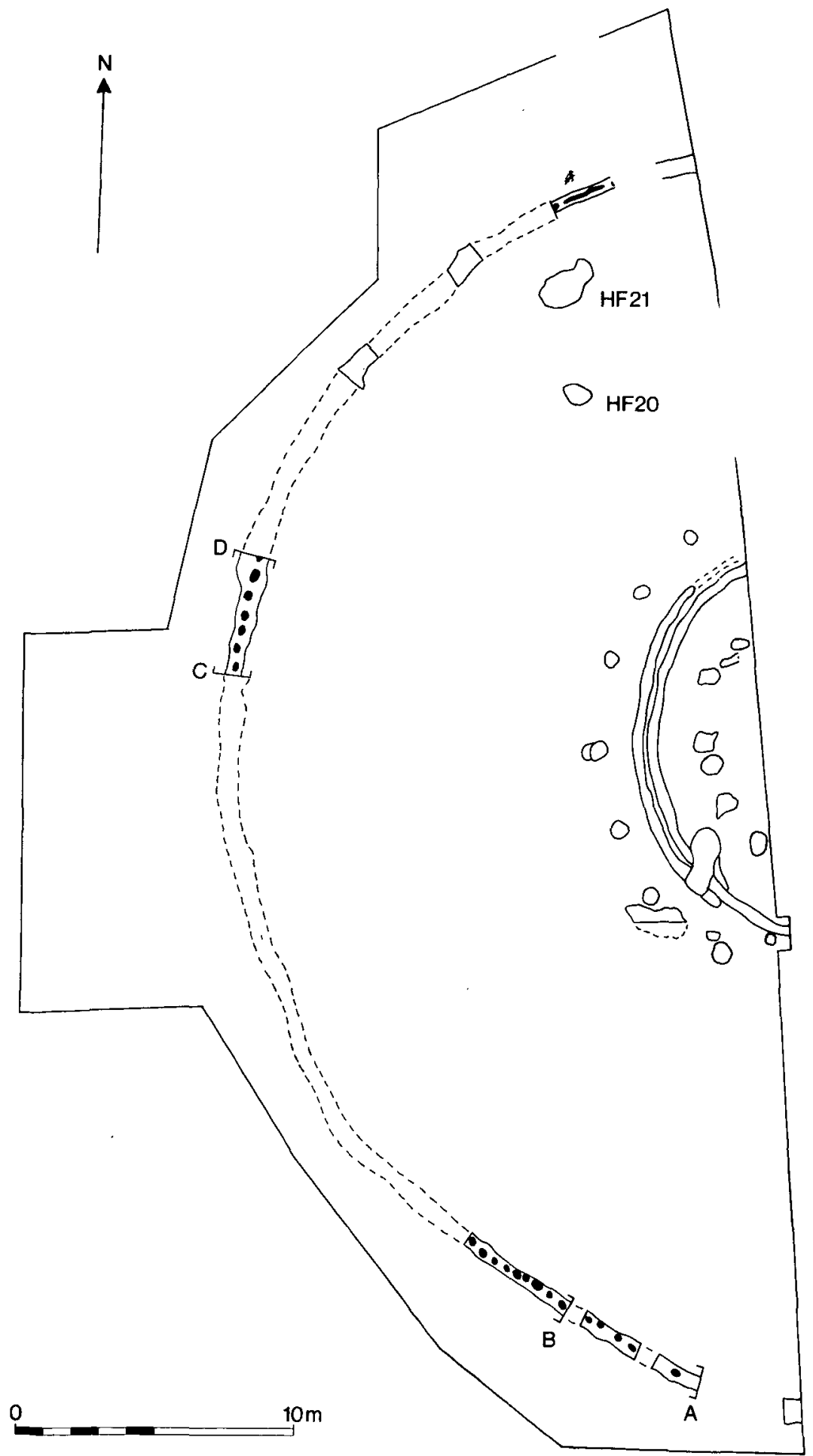

ILLuS 3 Homestead 1 plan; the sections are on illus 6a; the gap in the line of the palisade to the south is caused by the unexcavated plinth upon which the rectilinear building stood; the house details are on illus 7 


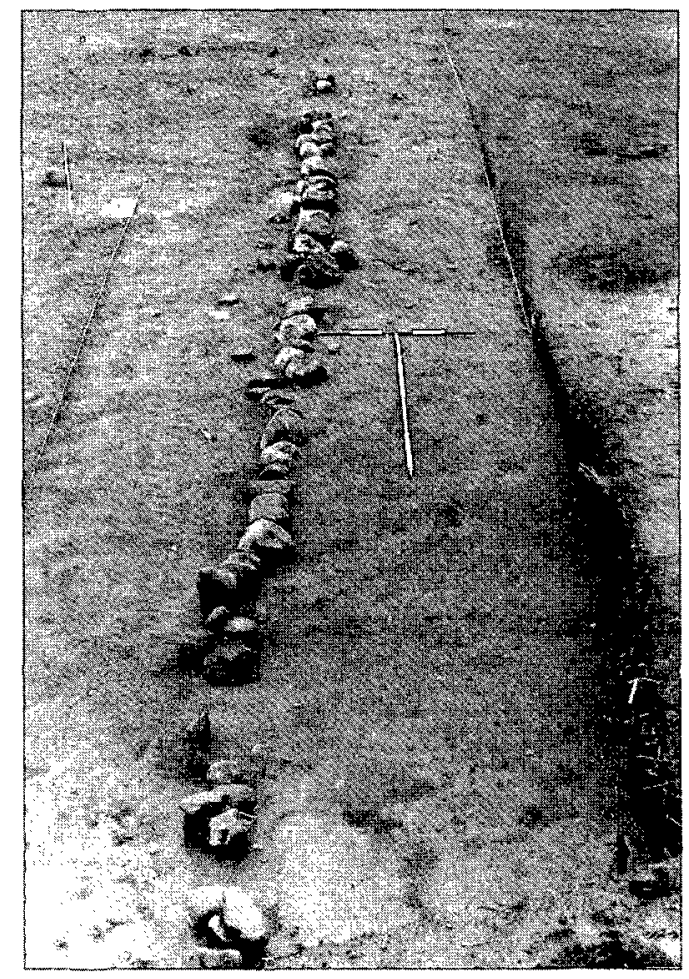

ILLus 4 Homestead 1 - stone line, from the north

on the south side where truncation seems to have been most severe (sections on illus 6a). The bottom was more or less level around the circuit. There were few packing stones. The upper, main fill of the palisade produced coarse pottery (60/18), a flint flake (60/30) and some fragments of burnt bone. The packing soil also produced coarse pottery $(60 / 26$, illus 27$)$.

Individual post-pipes were identified in plan in the lower fills of the trench in five of the nine sections excavated into it. The posts had been closely spaced and roughly circular, between $0.3 \mathrm{~m}$ and $0.4 \mathrm{~m}$ diameter and set between $0.05 \mathrm{~m}$ and $0.2 \mathrm{~m}$ apart. Coarse pottery $(60 / 23,60 / 27)$, a chert flake $(60 / 29)$ and fragments of burnt bone were recovered from post-pipes. The bottoms of postpipes of an earlier phase of wall, sealed under a thin layer of redeposited natural sand, were found in three of the cuttings. These earlier posts had pressed down into the natural sand leaving thick plank-shaped depressions in the sand, filled with dark brown or red sandy loam. Refurbishment took place in the original cut, except on the west side where a shallow recut, which strayed outside the original trench, contained a third phase of palisade. Selective refurbishment, in the form of a shallow oblong recut containing a substantial amount of stone packing, was noted on the south side of the palisade (not illustrated). A worked cobble $(60 / 25)$ was recovered from the recut. The upper fill of the palisade trench was mostly a dark red and brown sandy loam which extended all the way to the bottom of the post-pipes as a homogeneous soil fill. The upper packing soil was less loamy but had been affected by slumping, caused probably by settling as the timbers rotted away and by soil processes.

It is difficult to estimate the degree of truncation of the subsoil caused by the later rig and furrow cultivation. As noted above, the palisade trench reduced in depth from north to south, suggesting that on the south $0.3 \mathrm{~m}$ or more had been removed by agricultural activity. Uncertainty about the original depth of the palisade trench affects any attempt to reconstruct the original height of the palisade. In addition, the soft nature of the subsoil may also mean that caution should be exercised when considering its height. It was noted that the posts from the first phase 


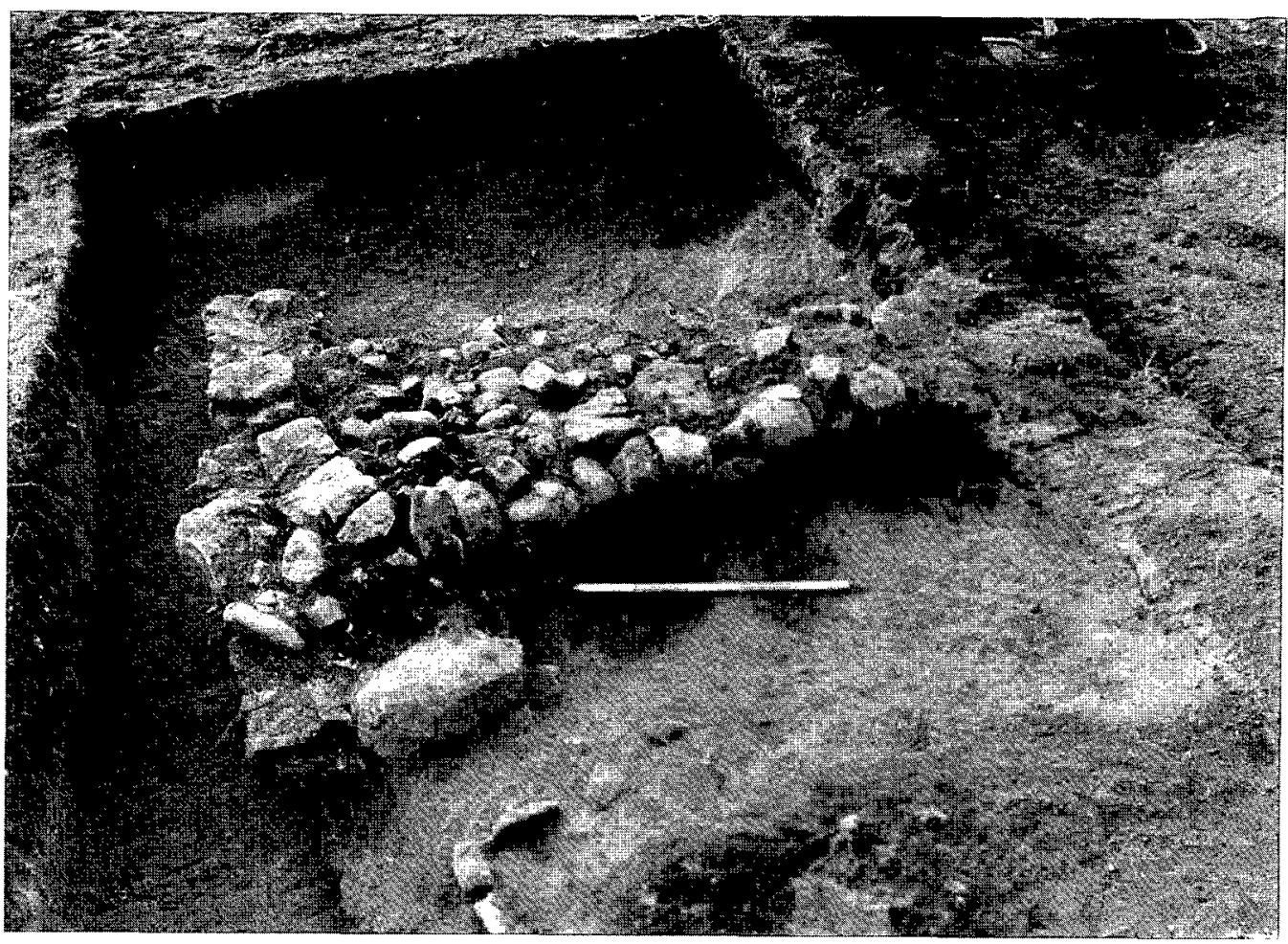

ILlus 5 Homestead 1 - remains of the building in the south-east corner of the site, from the east

of the palisade had left thick plank-shaped depressions in the natural sand. This shaping may reflect either that a plank wall was used originally, or that the ends of possibly round posts had been shaped so as to give maximum lateral resistance to rocking in the soft sand subsoil. It is likely that any tendency to become loose would very quickly be acted upon by the wind in such a soft subsoil and lead very quickly to a need for rebuilding. That rebuilding was required was shown by the three periods of trench-building at one of the cuttings across the palisade. It is not known, however, if the whole of the palisade needed replacement or if this was partial. The short length of later rebuilding at this point, and the partial refurbishment of Palisade 2 at the fort, suggests that the latter may have been the case. Two periods of construction of the house, however, could indicate that total refurbishment of the palisade was undertaken.

\section{The house}

Approximately one-third of the house lay within the excavated area. Most of the features found belong to the major structural elements of the house, which consisted of an inner post-ring (10.4 m dia), two wall lines (15.8 $\mathrm{m}$ and $14.5 \mathrm{~m}$ diam) and an external post-ring (18.6 $\mathrm{m}$ in diam).

The outer of the two wall lines was set in a trench $0.25-0.35 \mathrm{~m}$ wide which survived to a maximum depth of $0.10 \mathrm{~m}$ and had been almost entirely truncated on the north side (illus $7: 1$ ). There were a few packing stones but no tangible evidence of the construction method was found. On the south side the wall trench stopped at a small post-hole. It seems likely that this feature and a post-hole $0.2 \mathrm{~m}$ in diameter to the southeast (illus 7 : 19) represent an entrance through this wall not matched in the inner wall line. A small sherd of post-medieval pottery (60/17) was found in the outer wall trench. The inner wall (HF2) had been set in a deeper trench, 0.25 $0.35 \mathrm{~m}$ wide and surviving to a depth of $0.3-0.35 \mathrm{~m}$. At the bottom, the timbers had settled $0.03 \mathrm{~m}$ into the 


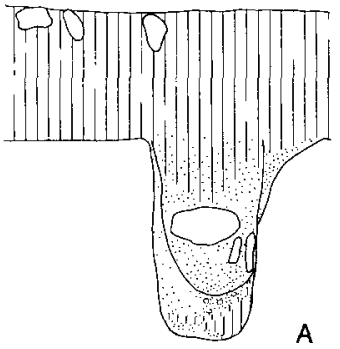

A

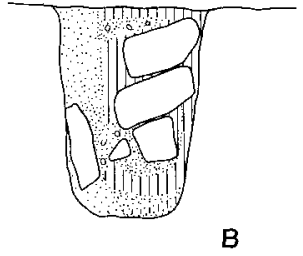

B

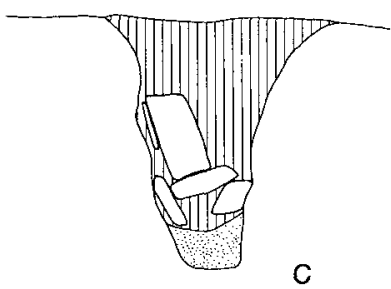

C
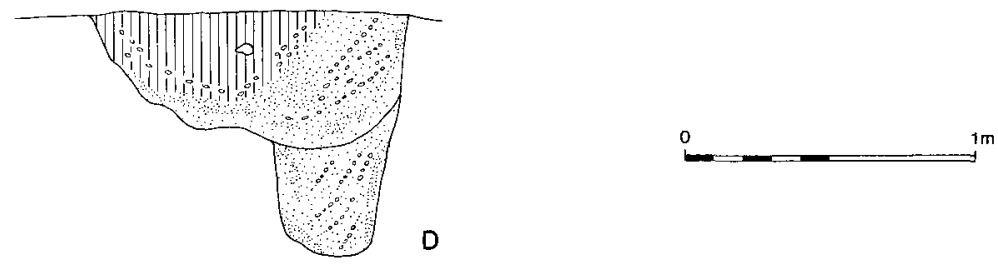

ILlus 6a Homestead 1 palisade sections as marked on illus 3, clockwise from the south-east corner

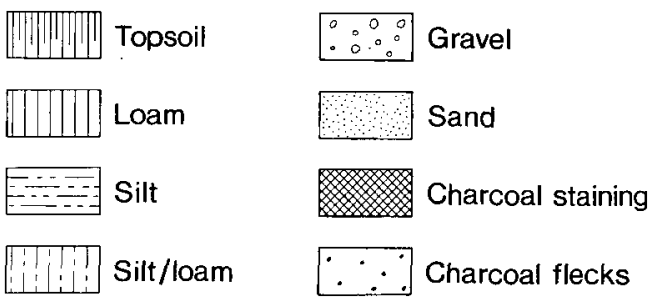

ILlus $6 \mathrm{~b}$ Key to the conventions used in all section drawings - the symbols may be mixed

sand, leaving clear impressions indicative of a continuous double plank wall $0.15-0.25 \mathrm{~m}$ thick. There was no indication of an entrance.

Both wall lines were cut by a dumbbell-shaped pit $2.4 \mathrm{~m}$ long and $0.7-1.2 \mathrm{~m}$ wide (HF22). The sides were almost vertical and the bottom slightly concave. The bottom layer was heavily charcoal flecked and a medieval iron knife $(60 / 22)$ lay on the subsoil in the bottom north-eastern corner. The upper fills indicated that the two lobes had been backfilled together. A sherd of Iron Age pottery (60/28) and a possible sling stone (60/15) were also found in the pit.

Of the seven features (HF3-9) excavated in the inner post-ring, two (HF5 \& HF6, illus 7: 5 \& 6) lay $0.25 \mathrm{~m}$ farther out from the projected centre for the house and may belong to a second ring. With the exception of the southernmost feature which was $0.5 \mathrm{~m}$ deep, the post-holes survived to a depth of $0.15 \mathrm{~m}$ or less. The remnants of post-pipes from three of the features indicate circular posts of about $0.40 \mathrm{~m}$ in diameter. The external post-ring consisted of seven posts (HF10-16) set more deeply than the inner ring, and contained circular posts between 0.3$0.4 \mathrm{~m}$ in diameter (illus 8 ). One of the post-holes (HF15) produced a small sherd of medieval or Roman coarse pottery (60/16). A post-hole, HF18 and two pits, HF17 and HF19, were found in the area of the outer ring.

The house almost certainly underwent two phases of construction as demonstrated by the two closely set concentric wall lines, the outer with a probable entrance on the south side. The difference in depth between the 


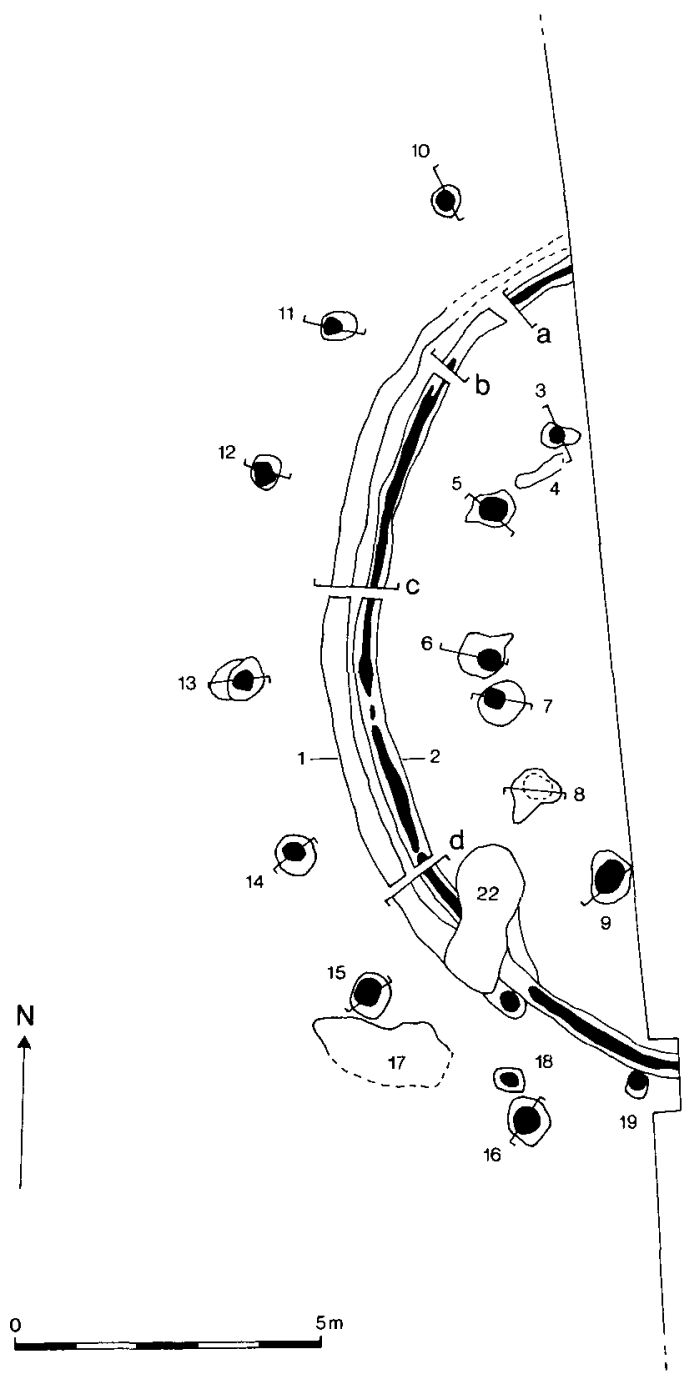

ILLUS 7 Homestead 1 house plan - post and timber shadows seen at various stages of the excavation are in solid black; the numbers relate to the HF numbers in the text; the sections are on illus 8

two grooves could indicate that, on such soils, erosion could be caused simply by occupation of the house and that rebuilding was necessitated by impending collapse. In this case, it would suggest that the inner groove replaced the outer in the same way that the later House 4 was better preserved than its predecessor, House 3 , to the south of the fort (below). Evidence of refurbishment of the internal and external post-rings is more of a problem. While it is possible that the two posts out of line in the internal ring could belong to the earlier house, the difference in depth of most of the posts compared to the depth of the grooves would suggest that the posts relating to the house with the shallower groove may well have been completely removed by erosion. This would have been the case in House 1 (below) in the homestead period of the fort if erosion had been slightly more 

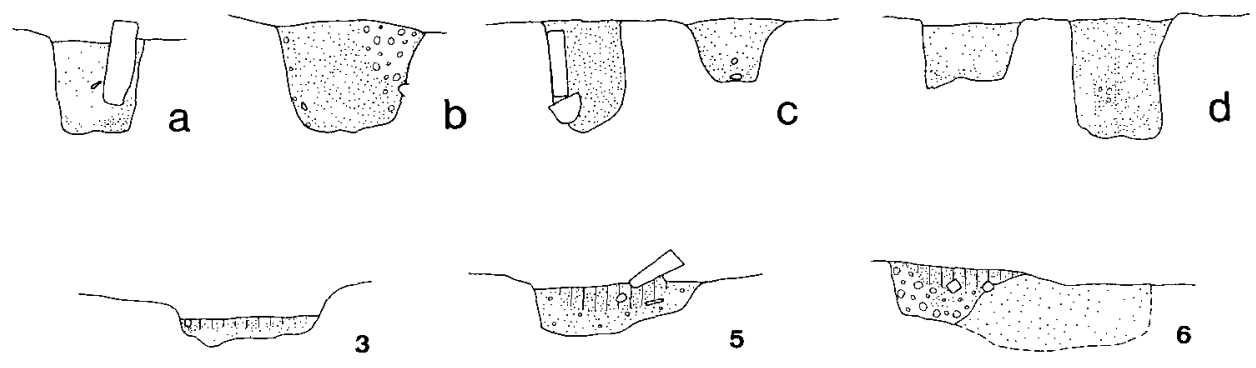

5

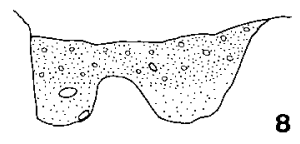

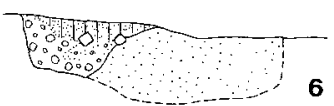

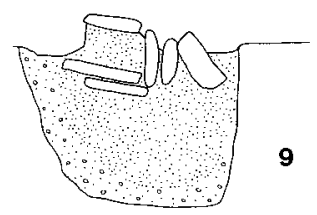

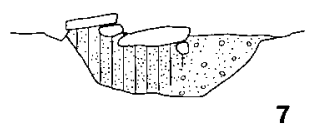

7

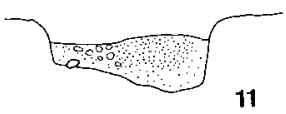

10
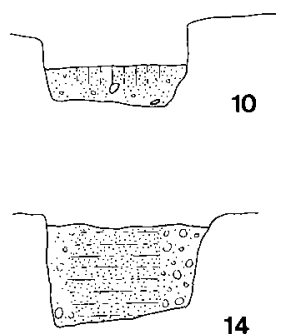

14

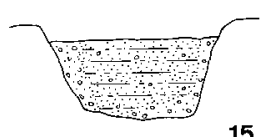

15

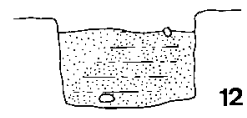

12

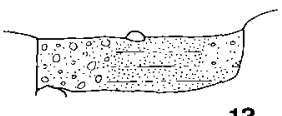

13

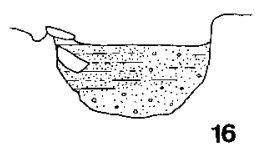

16

ILlus 8 Homestead 1 house sections as marked on illus 7 - the top row are ring-groove sections; the middle two rows are inner ring post-holes; the lower two rows are outer ring post-holes

severe. In the present case, in Homestead 1, the external post-ring posts were as substantial as those of the inner ring, suggesting that the outer ring performed a major load-bearing function.

No potential radiocarbon-dating sample could be recovered from either the house or palisade.

\section{The enclosure}

Within the area enclosed by the palisade, apart from features either demonstrably or probably associated with the house, only two possibly contemporary features were found. A small pit, $1.21 \mathrm{~m}$ by $0.90 \mathrm{~m}$ and $0.47 \mathrm{~m}$ deep, produced no evidence to indicate its date or function (HF20, illus 3). A larger pit, HF21 immediately to the north, $2.21 \mathrm{~m}$ by $1.31 \mathrm{~m}$ and $0.30 \mathrm{~m}$ deep, contained burnt soil mixed with charcoal towards the bottom whilst below this in the centre, the sand subsoil had been fired a deep red colour. It is possible that this had a similar function to the cooking pits excavated at Myrehead Farm (Barclay 1983, 64). Two sherds of postmedieval pottery were found in the very top of pit HF20 (60/2). It is possible that they are associated with the overlying agricultural activity rather than the pit. No features were found outside the palisade.

\section{Phosphate survey}

A phosphate survey was conducted at the homestead to see whether or not any patterning of phosphate levels coincided with the structural rings of the house. The sample points were at $0.5 \mathrm{~m}$ intervals. In addition to the area of survey across the house, three lines of samples using the same interval were run across the enclosure 
and out to the trench edges to west, south and east, to provide background samples with which the results from the house could be compared. The method used was that outlined by McCawley \& McKerrell (1972). The results from the lines to the south and east of the house indicated very low to medium levels of phosphate whilst there were high levels of phosphate around the area of the probable cooking pit and the palisade on the northern line. In all three lines the phosphate level increased markedly in the vicinity of the house. Islands of high phosphate levels were recorded between the wall trench and the outer post-ring.

\section{The artefacts}

Jenny Shiels

Homestead 1 produced a few finds, and of limited range. Iron Age pottery $(60 / 18,23,26,27,28)$ and a spindle whorl (60/9) conform to the pattern of finds from the fort for the same period, with a number of post-medieval sherds making up the majority of the total material retrieved. An iron knife with a whittletang (60/2) may date to between the 12th and 14th centuries $\mathrm{AD}$ and is, therefore, rather earlier than the post-medieval pottery, but none of this material is securely contexted. As with the fort, a long period of sporadic activity is suggested by the finds.

\section{HOMESTEAD 1: CONCLUSION}

The remains at Homestead 1 fall mostly into two periods: the Iron Age, and medieval and later activity. The Iron Age is represented by the palisaded homestead which has two phases. The first phase activity included the palisade and a round-house with wall trench and inner and, probably, outer post-rings. In the second phase, the palisade appears to have been reconstructed and the house rebuilt in a slightly different position on the same stance. The two discrete features within the enclosure but beyond the round-house, post-hole HF18 and pits HF17 and HF19 beside the house, may belong to the same period.

The dumbbell-shaped pit HF22 cuts the wall trenches and the presence of the iron knife at the bottom of its lower fill indicates a medieval date. Activity of a somewhat later date is indicated by the post-medieval pottery, the rig and furrow cultivation and the remains of the rectilinear stone building.

\section{THE FORT}

\section{James S Rideout}

\section{FIRST SEASON (1982)}

Throughout the first season all areas on the rough pasture 'nose' of the promontory, with the exception of certain ditch sections, were stripped and excavated by hand (illus $9 \& 11$ ). The reasons for this are twofold: access for machines was impossible before the crop in the field to the south was harvested, and it was hoped that structures might survive close to the surface. The summit of the nose of the promontory was excavated in two stages because of space restrictions controlling spoil dumping (Area 1, illus 11). As events proved, ploughing had removed all coherent evidence for structures and surfaces in the uppermost $0.3 \mathrm{~m}$ of the site.

Topsoil finds included a broken Bronze Age stone battleaxe from the B/C horizon (SF 45/67, illus 30), a stone spindle whorl (SF 45/2, illus 30), and a glass bead (SF 45/160, illus 29). Other finds recovered during stripping of Area 1 included coarse pottery $(45 / 146,45 / 156,45 / 144,45 / 168$ (illus 27) from the A-horizon and 45/58 (illus 27), 45/64, 45/96, 45/60, 45/74, 45/76-7, 45/84, 45/ $88,45 / 110$ from the B/C-horizon) and medieval pottery $(45 / 6,45 / 23,45 / 13-4,45 / 20-2,45 / 164,45 /$ 633 from the A-horizon, 45/37 from the B-horizon and 45/26, 45/65, 45/71, 45/73, 45/86, 45/87, 45/ $104-5,45 / 108-9,45 / 117,45 / 119,45 / 466$ from the B/C-horizon). Corroded iron objects were found in the A-horizon (45/151, 45/153-4), the B/C-horizon (45/80) and the subsoil (45/31). A quartz flake 


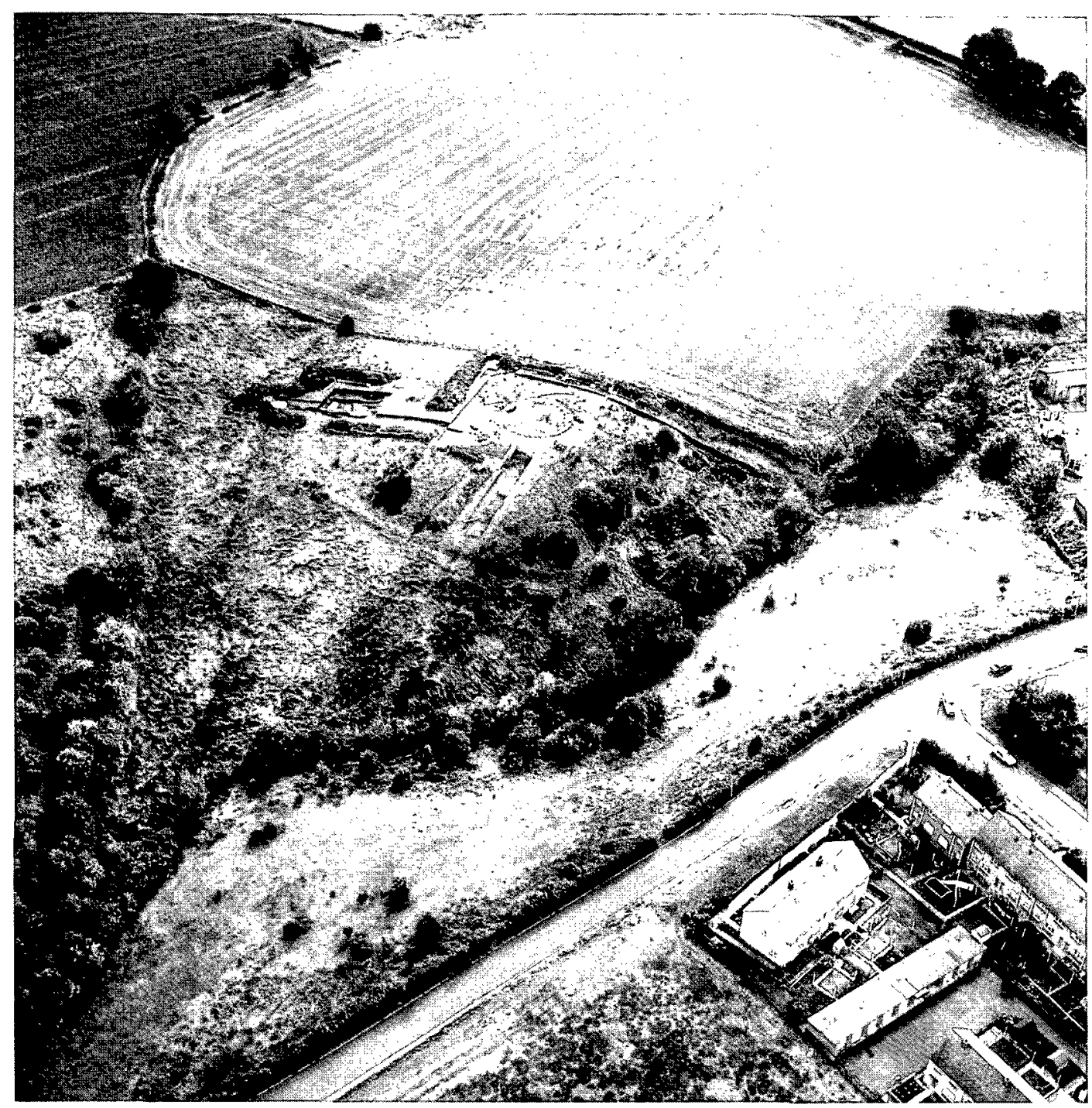

ILLuS 9 Aerial photograph of the 1982 Fort excavation from the NNW. The second fort season was in the cropped field above the 1982 trench; Homestead 1 is under the trees nearest the upper left corner; the ruins of Wester Greenyards are at the top edge.

(45/49) was recovered in the B/C-horizon. Coarse stone artefacts from the stripping consisted of part of a perforated shale object (45/17) and utilized cobbles (45/136 and 45/161) from the A-horizon and a fragment of jet (45/695) from the subsoil surface. A fragment of copper alloy sheet (45/30) was recovered from the B-horizon. A flake of coarse pottery (45/62) and corroded iron (45/294) were recovered from animal disturbance and a sherd of medieval pottery (45/400), an iron object (45/474) and a chert flake (45/252) from modern quarry-pits. Unstratified finds from Area 1 include coarse pottery $(45 / 18)$ and coarse stone artefacts (45/89-91).

Trenches (Areas 2-4) were opened to the west, north, and east to investigate the flanks of the promontory. Excavation of the defences on east and west sides of the promontory was hindered by 


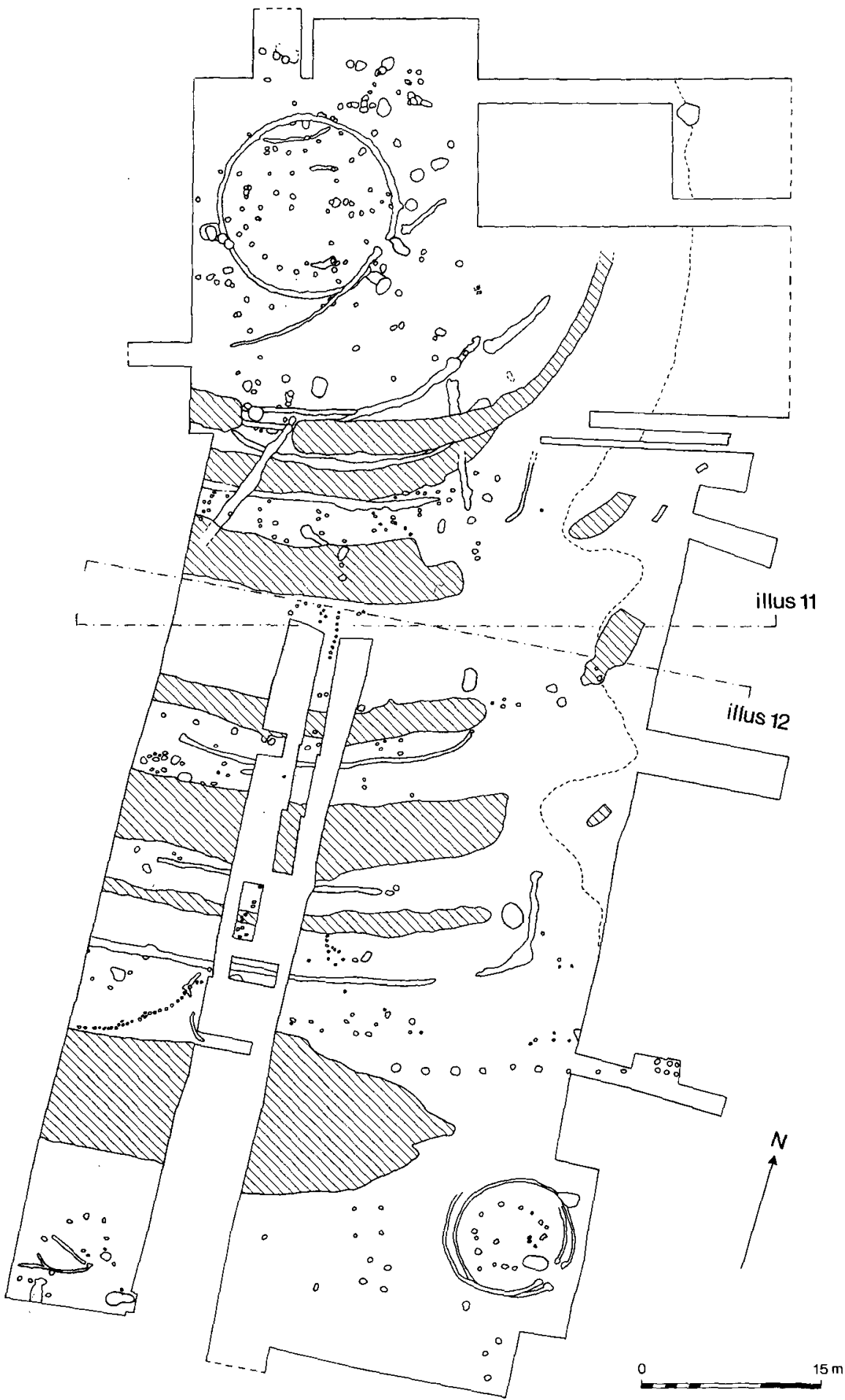

ILLus 10 Fort plan showing the relationship between illus 11 and illus 12 where context numbers can be found - the ditches are hatched 

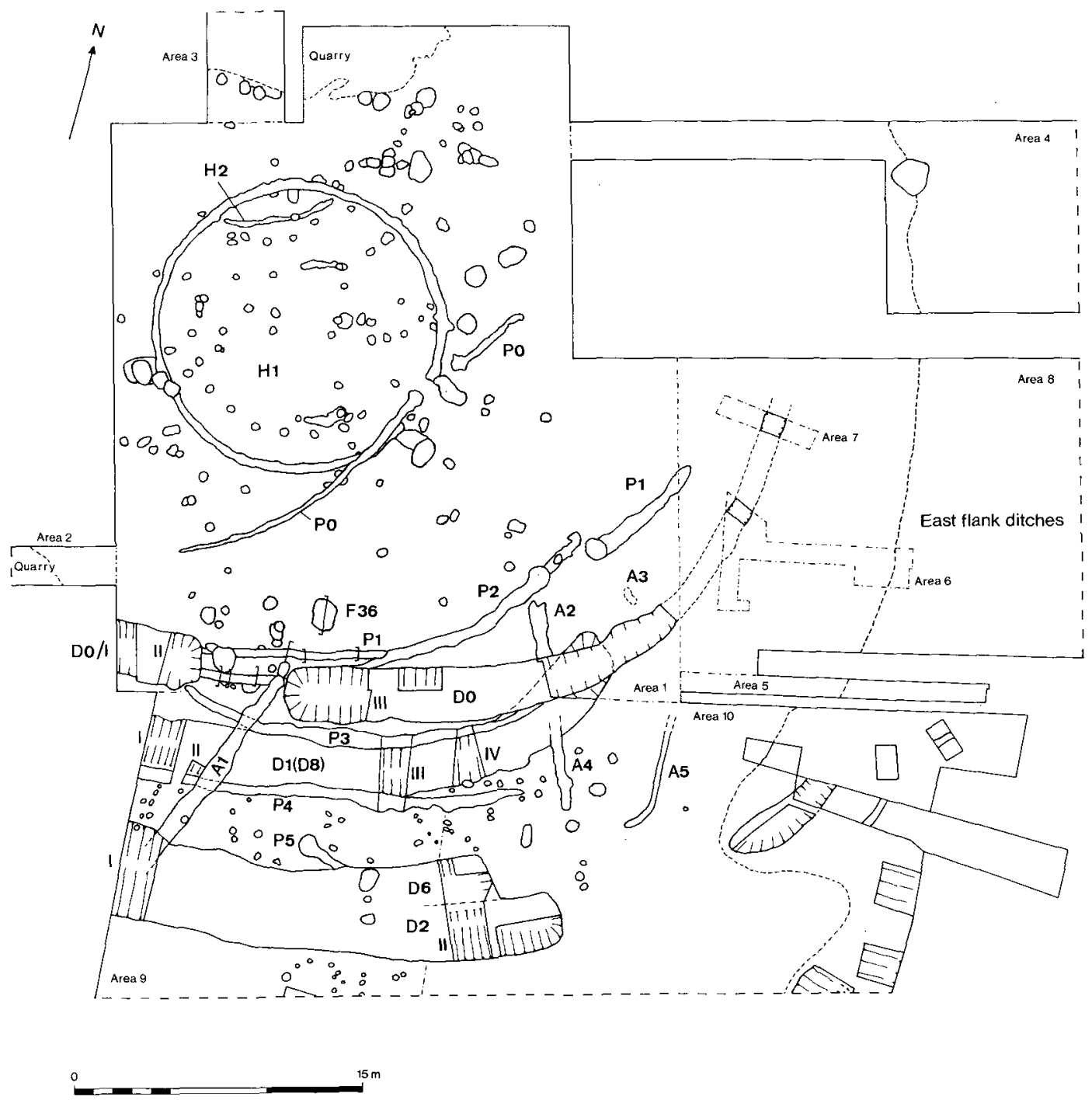

ILLUS 11 Fort interior plan showing the area of the 1982 season and part of the defences excavated in $1985 ; \mathrm{P}=$ palisade, $\mathrm{D}=$ ditch, $\mathrm{A}=$ antenna slot, $\mathrm{H}=$ house; P1/P2 sections on illus 17; F36 section on illus 22; the pecked lines at the edges of the plan show where trenches extend beyond the page

the unstable nature of the soils which led to sections collapsing at no great time after trenches were cut. The major features located in Area 1 included a large ring-groove house ( $\mathrm{H} 1)$, part of a second large ring-groove house (H2), a light fence or palisade (P0), and miscellaneous pits and post-holes. A refurbished palisade ( $\mathrm{P} 1, \mathrm{P} 2)$ with an entrance and possible antenna palisade (A2, A3) was found to the south. This was cut by a ditch (Ditch 0 ), not noted in the trial trench of 1974 , which had an entrance to the south. This ditch cut another, Ditch 1 (numbered during the 1974 excavation). The upper part of Area 2 was affected by severe modern disturbance; in the lower part were complex defensive ditches, mostly in boggy ground. Most of the Area 3 trench cut across severe modern 

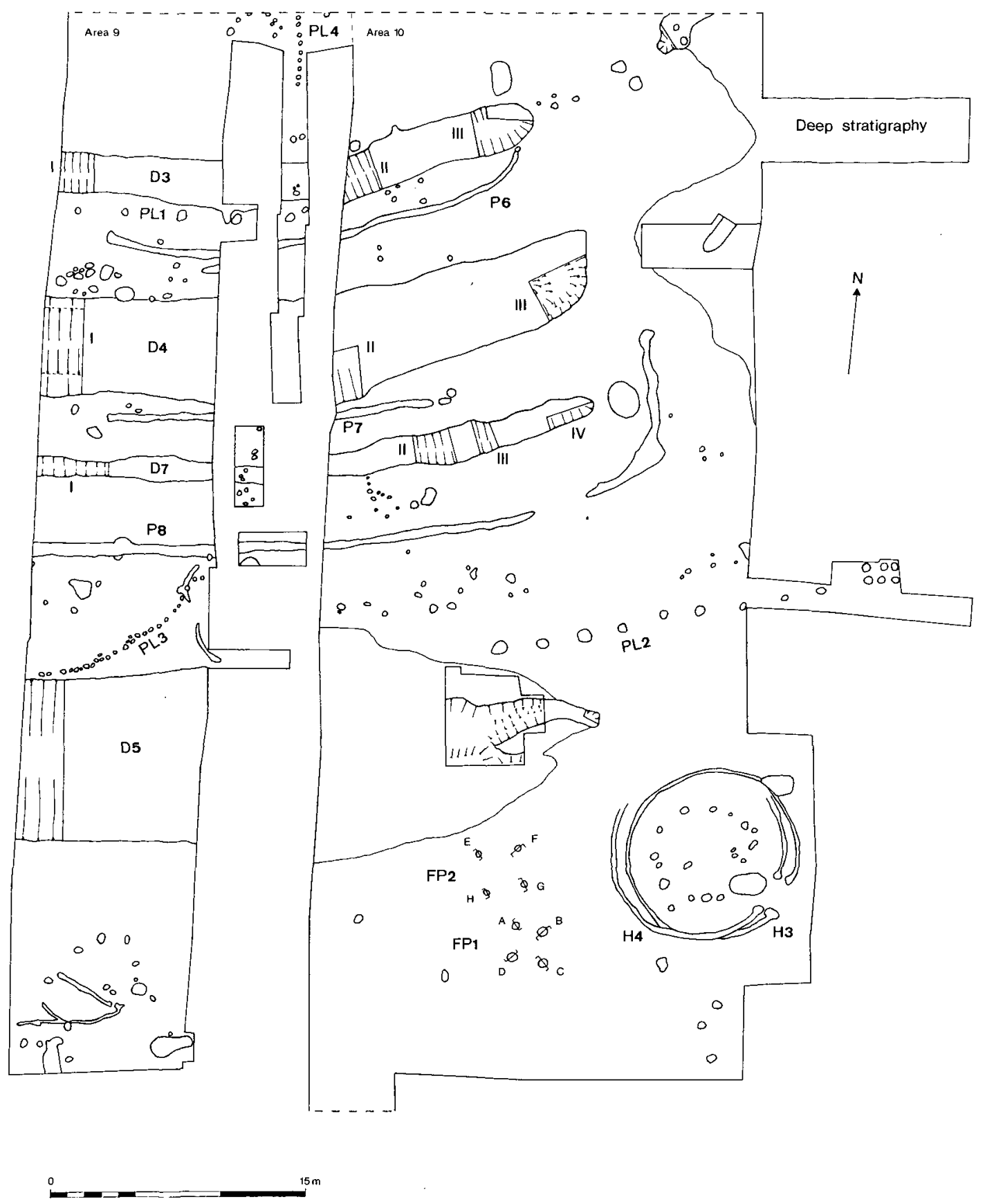

ILlus 12 Fort defences plan - southern defences; $\mathrm{P}=$ palisade, $\mathrm{D}=$ ditch, $\mathrm{A}=$ antenna slot, $\mathrm{H}=\mathrm{house}, \mathrm{PL}=$ postalignment, FP $=$ Four-post structure - sections on illus 26; the pecked lines at the edges of the plan show where the trenches extend beyond the edges of the page 
disturbance. With hindsight, the trench was not long enough to reach defensive works assumed to exist to the north of the fort. The upper parts of Area 4 were sterile. An expansion to this trench on the lower flanks located complex defensive works showing as ditches repeatedly cut and recut in sandy subsoil. The east end of the trench provided a peat monolith for pollen assessment. Areas 57 were three small trenches designed to investigate the line of the defences found in Area 1 (marked by dot-dash lines on illus 11). The trenches showed that the defences were severely truncated on the upper flanks.

Following the first season, analyses were carried out on much of the material recovered. Analyses of the 1985 material, therefore, were conducted separately. This is reflected in the layout of the specialists' reports and catalogues (below).

\section{SECOND SEASON (1985)}

A 10-week final season started at the beginning of April 1985. A large area was opened by machine in three main areas. Area 8, designed as a second attempt to understand the defences on the east flank of the promontory, was opened to the north of the arable field. This area subsumed the first season Areas 5-7. As in the 1982 season, excavation in this part of the site proved difficult because of the unstable nature of the deep deposits. On the summit of the promontory, in the arable field, two large areas were opened to investigate the defences (illus 10 \& 12). Area 9, to the west, originally measured c $82 \mathrm{~m}$ north/south by c $10 \mathrm{~m}$. Area 10, to the east of Area 9 , measuring $80 \mathrm{~m}$ north/south by $25 \mathrm{~m}$, was designed to investigate the probable entrance area noted on the aerial photographs. Areas 9 and 10 were subsequently linked at the north end to investigate complex inner defence features. Smaller trenches to investigate various features were cut into the wide baulk between Areas 9 and 10 and to the east and south of Area 10. The north end of Area 9 continued into the meadow field to link up with first season Area 1. A flint flake (94/130) and medieval pottery (94/2-3) were recovered from the Area 9 A-horizon. A fragment of coarse pottery (94/31), quartz flakes (94/105 a \& b), medieval pottery $(94 / 18,94 / 20-1,94 / 25,94 / 29,94 / 32-38)$ and a modern curry-comb (94/ 19) were found in the A-horizon over Area 10 and a sherd of coarse pottery was recovered from a soil sample (G2577) from animal disturbance. The B-horizon produced a sherd of medieval pottery (94/24). Another sherd of medieval pottery $(94 / 141)$ was recovered from recent hillwash. Unstratified finds of medieval pottery $(94 / 46,94 / 66,94 / 103,94 / 113,94 / 139,94 / 143,94 / 152)$ and an unstratified shale disc $(94 / 132$, illus 30$)$ were also recovered.

Areas 9-10 exposed the defences on the promontory summit. Three ditches (D6-8) were added to the six already known (D0-5). Six further palisades (P3-8), some known from aerial photographs, were located, as were at least three post alignments (PL1-3). Two houses (H3 \& H4) superimposed were found on the line of the main entrance through the defences and beyond the outermost ditch, Ditch 5. To the southwest of the houses were two four-post structures (FP1 \& FP2). Two arcs of groove in Area 9 may represent two further houses. Along the east side of Area 10, was the upper limit of the deep deposits as found in Area 8. Trenches cut into these deposits investigated ditches and palisades.

\section{CONTEXT DESCRIPTIONS AND INTERPRETATIONS}

\section{Defences}

The defences are described in the order of inner to outer (north/south) rather than in stratigraphic order, starting with ditches, followed by palisades, antenna palisades, and post alignments. Widths 
are as taken at the subsoil surface and depths are below the subsoil surface. The numbering system follows and expands upon the numbers used by the original excavations by the SFAS in the 1970s (1974). Modern finds, and most of the tiny fragments of finds recovered during flotation, are omitted.

\section{The Ditches}

Ditch 0 (D0) This ditch was the only one with an entrance on a different alignment to the main approach from the SSE. The entrance to the south was $4.5 \mathrm{~m}$ wide. Some or all of various negative features immediately to the north of the entrance may represent a gateway structure. To the west of the entrance, a $4.5 \mathrm{~m}$ length of ditch was investigated in two cuttings (Ditch 0/I \& II) in the first season. All sections showed a U-sectioned ditch with lower fills of silting, derived from erosion of the ditch sides, and upper fills of more humic loam (illus 13, A). The ditch was $2.7 \mathrm{~m}$ wide and $1 \mathrm{~m}$ deep. It could not be traced into the upper part of Area 2; if it had existed here, modern disturbance has removed all traces. The ditch to the east of the entrance was investigated in both seasons. In the first season only the north part could be excavated because the modern fence, which was the southern boundary of the 1982 excavation, ran along the line of the ditch at this point. The fills were generally similar to those in the west ditch but a layer of burnt and charcoal stained soil was found $0.3 \mathrm{~m}$ above the bottom of the terminal. About $20 \mathrm{~m}$ to the east of the entrance, at the east edge of Area 1a, the ditch became narrower and shallower due to the severe erosion of the lip of the summit, but could be traced in Areas 6 and 7 (and, later, in Area 8).

Finds from Ditch 0 include late Bronze Age or Iron Age coarse pottery $(45 / 529,45 / 641,45 / 642)$, corroded iron $(45 / 574,45 / 576)$, a shale ring (45/585, illus 30), a flint flake (45/634), a quartz flake (45/703) and fragments of slag and daub, all from mid- to upper parts of the stratigraphy. Fragments of animal bone were also recovered (45/589, 45/583). Ditch 0 cut Ditch 1, Palisade 1, and Palisade 2.

Ditch 8 (D8) This ditch was discovered in the last season. Very little of the ditch survived, most of it having been replaced by Ditch 1 (see section drawings, illus 13, B \& c). Ditch 8 was at least $6 \mathrm{~m}$ wide and relatively shallow, $0.6 \mathrm{~m}$ deep in the westernmost cutting (D1/I). It was flatbottomed and filled with finely laminated silting of fine and coarse sands and humic silts. The ditch had filled, at least to the level of the modern subsoil surface, before Ditch 1 was cut. The extent of the ditch is unknown, but its similarity to Ditch 6 suggests that it may originally have terminated at the SSE entrance. No finds were recovered.

Ditch 1 (D1) Ditch 1 is deep and V-sectioned and terminates in line with Ditch 2 to D4. Most of its terminal was destroyed by Ditch 0 . Three main sections were cut across the ditch to investigate its relationship to other features. In cutting D1/I the ditch was $2.7 \mathrm{~m}$ wide and $1.6 \mathrm{~m}$ deep (illus 13 , B). The lower fills, to a depth of $0.7 \mathrm{~m}$, were laminated sands derived from the erosion of the ditch sides. The low humic content of this silting, and its depth, indicates that the erosion process was rapid and severe. The profile as recorded, therefore, shows the ditch as being wider than originally cut. The upper fills were much more humic, representing a more gradual growth of topsoil after the ditch had stabilised. The uppermost fill below the modern ploughsoil and B-horizon was a gravel of low humic content. This may be spoil from the cutting of a palisade or ditch at a stage when Ditch 1 survived only as a shallow hollow. The section shows Palisade 4 cutting the south lip of Ditch 1 . The east facing section of cutting D1/III showed a similar profile but with Palisade 3 cutting into the north half of D1/II (illus 13, c). Finds comprised medieval pottery (94/127) and a flake of agate (94/135) from high in the stratigraphy. Ditch 1 cut Ditch 8 and was cut by Ditch 0, Palisade 3, Palisade 4, and Antenna 4.

Ditch 6 (D6) Like Ditch 8, most of Ditch 6 had been removed by the cutting of a later $V$ sectioned ditch (D2). Ditch 6 was shallow and flat bottomed, $0.7 \mathrm{~m}$ deep. In cutting D2/I (illus 14, A), a small wedge of fills survived, while at its east terminal more survived (illus 14, B). The fills, like those in Ditch 8 , were laminated sands which had filled the ditch, at least to the level of the subsoil surface, before Ditch 2 cut it. The square butted terminal stopped $3 \mathrm{~m}$ short (ie to the west) of the terminal of Ditch 2. No finds were recovered. Ditch 6 cut Palisade 5 and was cut by Ditch 2. 

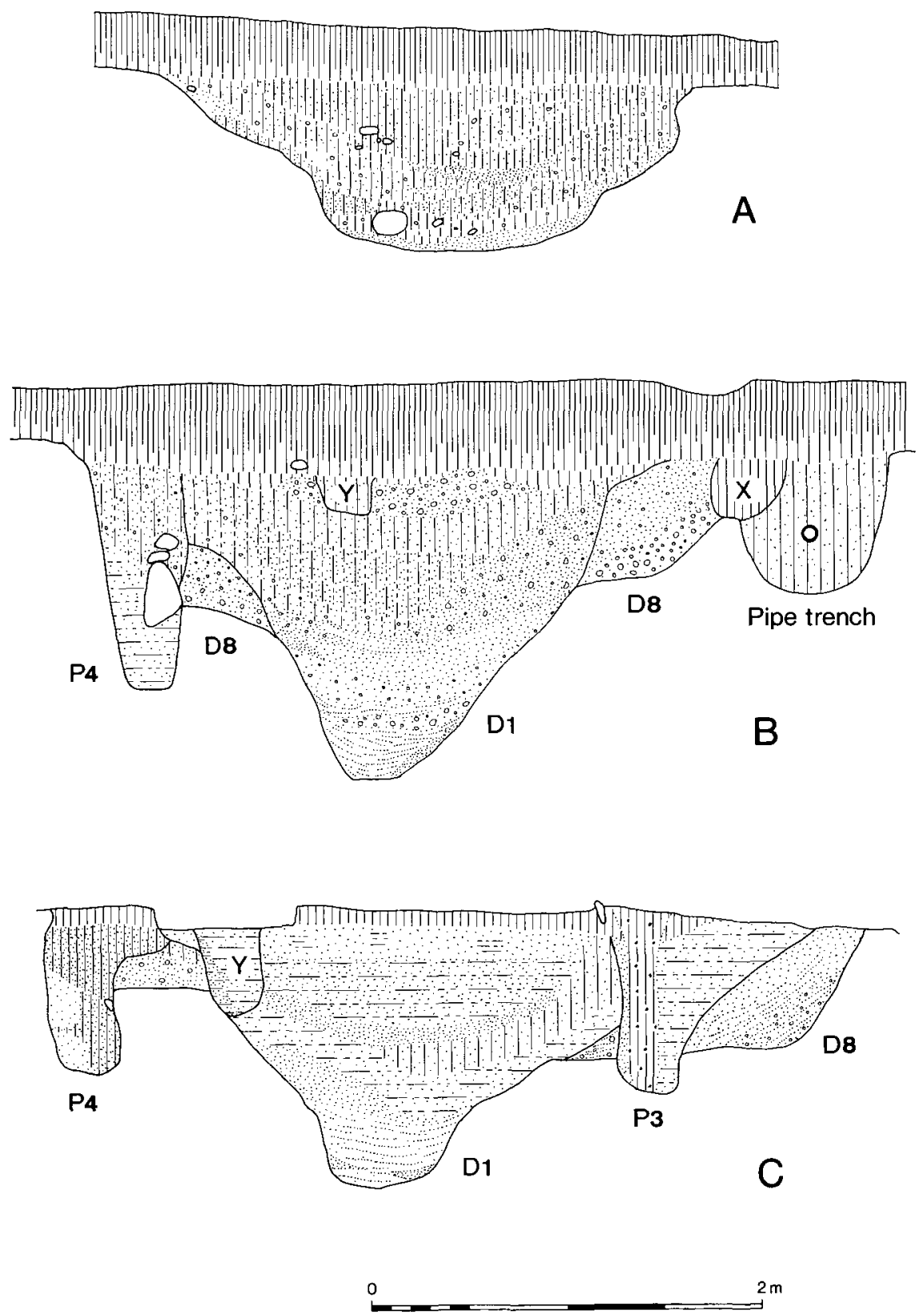

Illus 13 Fort - Ditch sections; A. Ditch 0; B. relationship between Ditch 1, Ditch 8 and Palisade 4 in Cutting D1/I; C. relationship between Ditch 1, Ditch 8, Palisade 4 and Palisade 3 in Cutting D1/III; all sections are east-facing; $\mathrm{X}=$ modern disturbance, $\mathrm{Y}=$ discrete feature 

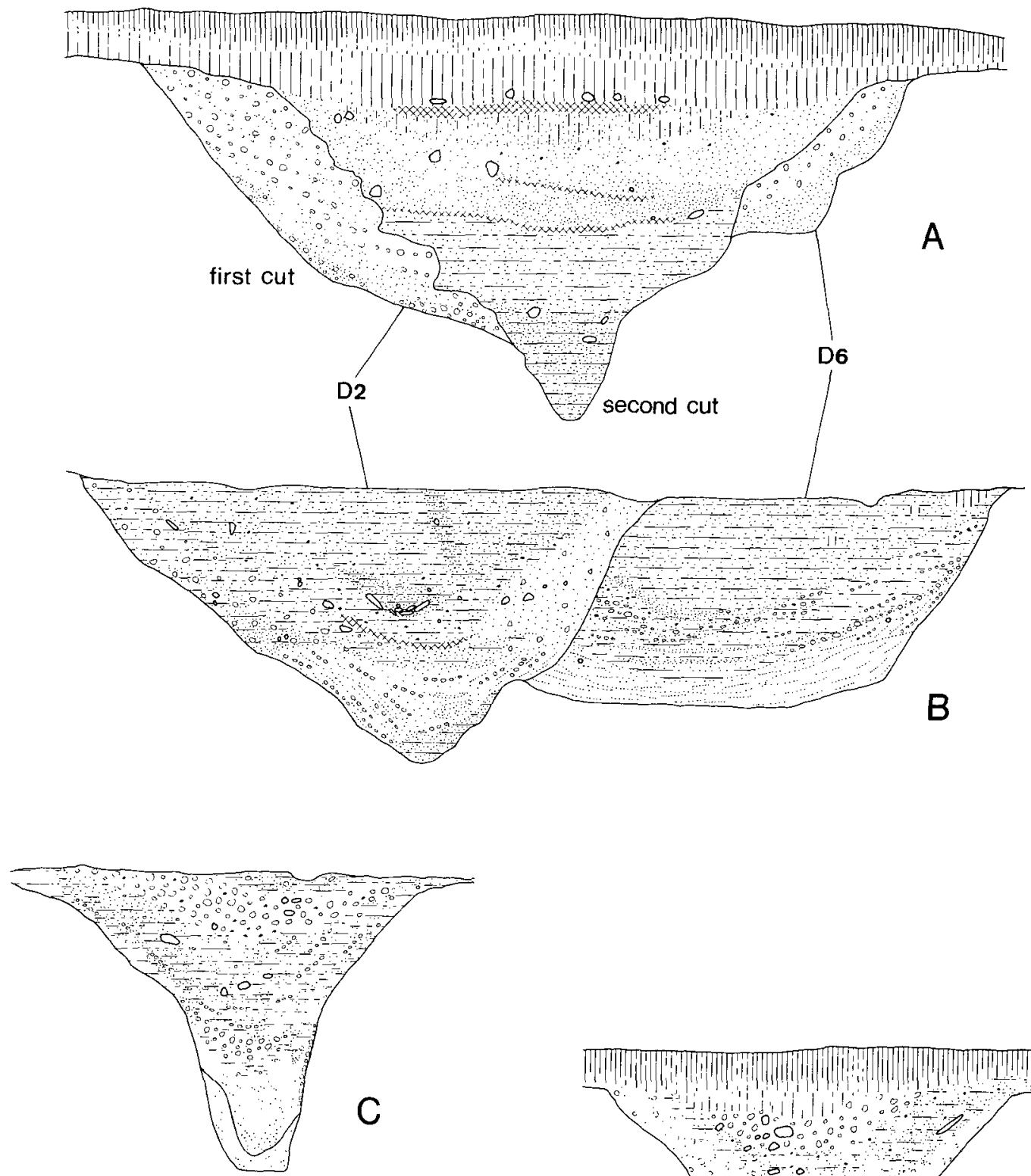

0

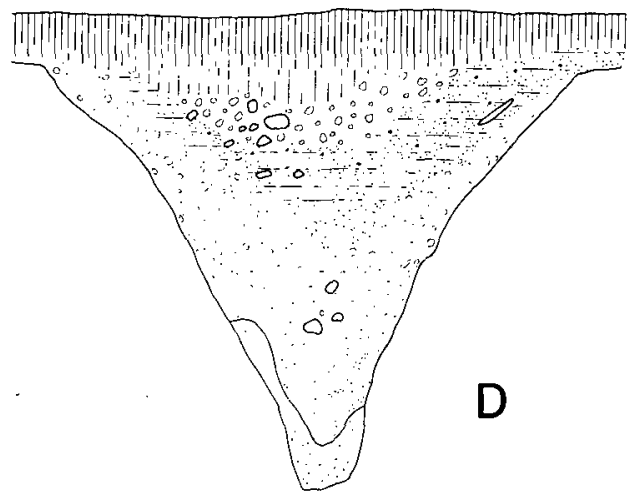

ILLUS 14 Fort - Ditch sections; A. recut in Ditch 2 and the relationship between Ditch 2 and Ditch 6 in Cutting D2/I; B. relationship between Ditch 2 and Ditch 6 in Cutting D2/II; C. recut in Ditch 3 in Cutting D3/II; D. recut in Ditch 3 in Cutting D3/I; ( $A, B$ and D are east-facing) 
Ditch 2 (D2) A deep, V-sectioned ditch replacing Ditch 6, Ditch 2 terminates at a rounded buttend in line with the terminals of Ditch 1, Ditch 3, and Ditch 4. At the section nearest the terminal (cutting D2/II, illus 14, B) it survived to a width of $3.0 \mathrm{~m}$ and a depth of $1.5 \mathrm{~m}$; near the terminal the depth was reduced to $1.0 \mathrm{~m}$ due to erosion of the subsoil. In the terminal cutting, the lower fills were inorganic silts and sands, while most of the upper fills were humic sandy loams, rich in charcoal, burnt bone, and pottery. The upper fills give the appearance of midden deposits, interrupted only by a wedge of inorganic silts and sands on the north side, possibly derived from an internal dump rampart, or from excavation of another ditch or palisade.

In cutting D2/I the ditch profile was more complex, with at least one recut (illus 14, A). The first cut has produced a broad V-sectioned ditch, as in cutting D2/II. The fills of this ditch, on the south side of the profile, consist of broad bands of coarse sands and gravels which represent a rapid backfill from the south side or possibly even collapse of the ditch side. These fills are truncated, to the north, by a steeper, deeper V-sectioned ditch with a very steep lower $0.5 \mathrm{~m}$. This part was filled with sorted coarse sands derived from weathering of the slopes above. The upper fills, from $0.5 \mathrm{~m}$ to $1.3 \mathrm{~m}$ above the bottom, were humic sandy loams interbedded with two lenses of charcoal-rich soil. The uppermost fills, and the fill of Ditch 6, appear to have been truncated by a broad, shallow, U-sectioned feature filled with humic loams. It could not be ascertained whether this was formed as a cut or simply as a result of erosion.

Medieval pottery (94/90) was recovered from the B-horizon over the ditch. Iron Age coarse pottery was found in high contexts $(94 / 97,94 / 100,94 / 109,94 / 114-6,94 / 118,94 / 119$ and a pottery fragment from sample G1206) and low contexts (94/126, 94/155, approximately one-third of a large vessel, illus 28). Ditch 2 cut Ditch 6 and was cut by Antenna 1.

Ditch 3 (D3) There was no direct stratigraphical relationship between Ditch 3 and the inner defences. The ditch was investigated in three cuttings. In the easternmost (D3/III), at the terminal, it was $1.7 \mathrm{~m}$ deep at the section but reduced to $1.0 \mathrm{~m}$ deep at the buttend. In the central cutting (D3/II, illus 14, c), the ditch was $1.6 \mathrm{~m}$ deep. The width at the subsoil surface does not reflect the original dimension. In the two eastern cuttings the sections showed a broad V-shaped profile in the upper part, becoming a much steeper V-profile with a flat bottom in the lower part. The lower part was filled with inorganic silts and sands containing lumps of redeposited naturally laminated sand. The broad V-profile, therefore, is a weathering cone representing the rapid collapse of the upper ditch sides. The original profile would have been very steep and narrow. The upper fills were more humic, and contained charcoal, burnt bone, and burnt stones.

In cutting D3/I, the ditch survived to a depth of $1.7 \mathrm{~m}$ and a width of $2.2 \mathrm{~m}$. At least one recut was visible: the lower fill of the ditch, representing an initial rapid infill to a depth of $0.6 \mathrm{~m}$, had been recut to partially clean out the bottom (illus 14, D). This recut and the rest of the original cut was filled up with sands and silts with low humic content. Like Ditch 2 in cutting D2/I, the upper fills have been truncated to a maximum depth of $0.5 \mathrm{~m}$. The broad, U-shaped depression was filled with more humic soils containing flecks of charcoal. Finds included medieval pottery $(94 / 14,94 / 16,94 / 22,94 / 23)$ from the modern B-horizon. Ditch 3 was cut by Palisade 6 and possibly Post Alignment 4.

Ditch 4 (D4) This was investigated in three cuttings: a transverse section $2.5 \mathrm{~m}$ wide beside the west baulk of Area 9 (D4/I, illus 15, A)), a partial section beside the west baulk of Area 10 (D4/II), and a transverse/axial section to investigate the terminal (D4/III). At the terminal, the axial section revealed a ditch with two, or possibly three, recuts (illus 15, в). The first cut, $1.0 \mathrm{~m}$ deep, was filled with laminated sands and fine gravels surviving in the bottom of the ditch. The second cut established a deeper ditch $(\mathrm{c} 1.5 \mathrm{~m})$ with its terminal $2 \mathrm{~m}$ to the west of the original. Only the lower $0.6 \mathrm{~m}$ of the fills survived, most having been removed by the third cut. This was slightly shallower than the second and moved the terminal a short distance to the east. The fills, like those of the first and second cuts, were inorganic silts and sands. The final cut truncated the upper fills of the first and third cuts. The terminal was moved to its original position but the ditch was much shallower (c 0.7 $\mathrm{m})$. This ditch, because of its shallower profile, had humic loam fills, rather than quickly infilled sands. Domestic debris was less evident than in Ditch 2 and Ditch 3. The second cutting was designed to investigate a marked widening in the ditch near the west baulk of Area 10 which was believed to be a truncated terminal. No terminal was found: the section showed a broad shallow ditch. In cutting D4/I, the profile was less complex (illus 15 , 

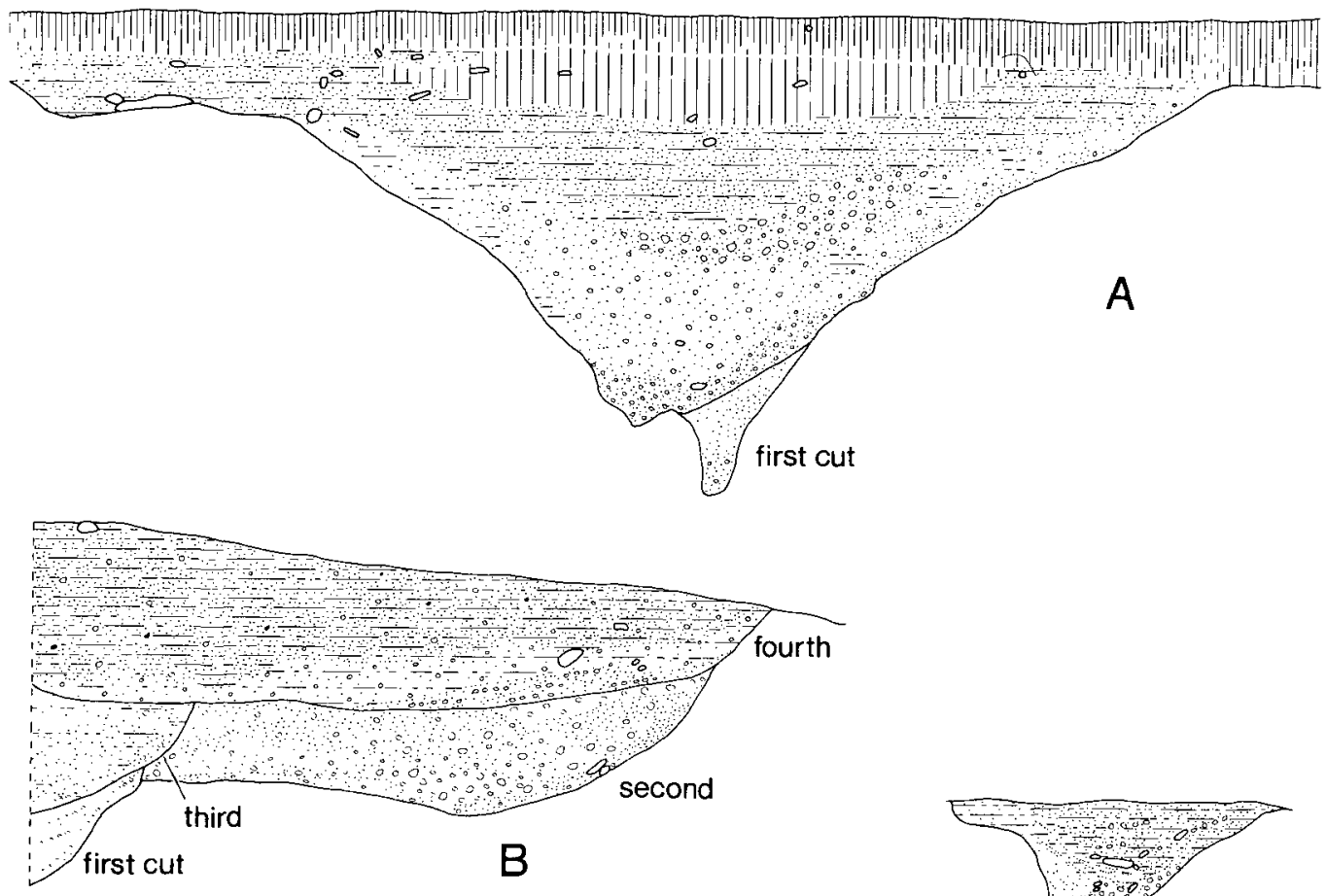

0 $2 \mathrm{~m}$

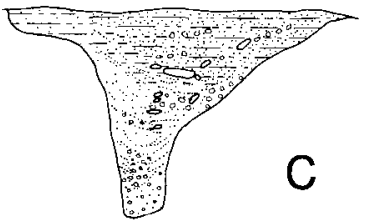

ILlus 15 Fort - Ditch sections; A. recut in Ditch 4 in Cutting D4/I; B. axial section, in Cutting D4/III, of the terminal of Ditch 4 showing four cuts; C. Ditch 7 section in D7/III; A and C are east-facing, B is south-facing

A). An original ditch cut with a narrow 'anklebreaker' had been replaced by a broad V-sectioned cut. Only the lower fills of the first cut survived, to a maximum depth of $0.6 \mathrm{~m}$. The bottom of the second cut was slightly to the south of the original. The second cut had filled with sands and silts in the lower part becoming increasingly humic towards the top. The first cut was $1.8 \mathrm{~m}$ deep; the second $1.5 \mathrm{~m}$ deep and $4 \mathrm{~m}$ wide. A quartz flake (94/ 27) was found in the B-horizon over the ditch. The A-horizon over the ditch produced medieval pottery (94/4, 94/76). Ditch 4 may have cut Post Alignment 3.

Ditch 7 (D7) Originally believed to be a palisade, this ditch was investigated in four lengths designed to provide axial and transverse sections to locate post-pipes or other evidence of palisading. The feature proved to be cut on a sinuous line with scalloped sides. In profile it resembled that of Ditch 3, with a shallow, sloped upper part and steepsided, flatbottomed lower part. The lower fills were finely laminated sands and fine gravels; the upper fills, laminated silty and sandy loam soils with some charcoal fragments. The lower loam fills contained angular stones of a uniform size of $0.10 \mathrm{~m}$. It is possible that this ditch, $1.4 \mathrm{~m}$ wide and $0.85 \mathrm{~m}$ deep in cutting D7/III (illus $15, \mathrm{c}$ ), represents an unfinished line of defence or possibly a marker trench for an unconstructed ditch. No finds were recovered. Ditch 7 was cut by Post Alignment 4.

Ditch 5 (D5) This showed, on aerial photographs and after topsoil stripping, as a very wide linear feature. A cutting in Area 9 showed that part of its apparent width was caused by deep furrows associated with broad 
rig-and-furrow. Three cuts could be identified in the east-facing section of cutting D5/I (illus 16). The first was a very broad U-shaped ditch at least $7.5 \mathrm{~m}$ wide and $2 \mathrm{~m}$ deep. This had filled with almost horizontal layers of fine and coarse sands to a depth of $1.6 \mathrm{~m}$, leaving a shallow depression. At some point a small $\mathrm{V}$-sectioned ditch was cut into the north side; only the base of this survived, with a fill of humic sand. This ditch was originally $1 \mathrm{~m}$ deep. A third cut, replacing the first ditch, cut through the fills of both previous ditches. Part of the fills of the first cut survived on both sides. The third cut was more $\mathrm{V}$-sectioned, $6.5 \mathrm{~m}$ wide and $2.5 \mathrm{~m}$ deep. The fills were more humic than those of cuts 1 and 2, becoming topsoil-like higher up. The section (illus 16) shows that the backfilled ditch was cut by a furrow of a medieval or post-medieval fieldsystem. A second furrow cut the subsoil immediately to the south of the ditch (ie just off the left side of the illustrated section). Although the surface indications suggested that, in Area 10, it continued east to a terminal, the ditch did not exist as such. Instead it appeared as a series of shallow irregular depressions. This has been interpreted as an unfinished part of the ditch which, at some point between cutting D5/I and Area 10, simply died out as a result of the abandonment of its construction.

Finds were many; from high in the final recut came Iron Age coarse pottery (94/58-63, 94/65, 94/67, 94/ $69-73,94 / 75,94 / 78)$, a burnt flake of flint $(94 / 57)$, and slag. From lower in the last recut was coarse pottery $(94 / 79,94 / 80,94 / 82,94 / 86,94 / 88,94 / 89,94 / 111)$, a burnt flake of flint or chert (94/99), and slag. From the B-horizon (and medieval field furrow) came medieval pottery $(94 / 7,94 / 9,94 / 11,94 / 12,94 / 50-52)$, a flint flake (94/13), a flake of agate (94/39), corroded iron $(94 / 5,94 / 41,94 / 42)$, flaked stone $(94 / 53)$ and slag.

\section{The palisades}

Palisade $0(\mathrm{P} 0)$ is described below, after the description of the house.

Palisades 1 \& 2 (P1 \& P2) Palisade 2 was a trench which held a palisade packed with stones in a matrix of loamy sand (see sections on illus 17). An entrance, to the southeast of House 1, and in line with its doorway, was $2.2 \mathrm{~m}$ wide (illus 11). The terminals at the entrance were bulbous. To the east of the entrance, the trench was shallow (truncated) but depressions in the subsoil at the bottom of the trench appear to reflect the positions of timber uprights. To the west of the entrance, in the terminal, was a large post-pipe $0.65 \mathrm{~m}$ in diameter. Palisade $2 \mathrm{had}$ an average width of $0.6 \mathrm{~m}$ and was between $0.30 \mathrm{~m}$ and $0.65 \mathrm{~m}$ deep.

At a slightly later date, but probably while Palisade 2 still stood, Palisade 1 was constructed. It abutted Palisade 2 at a point $9.5 \mathrm{~m}$ to the west of the entrance, the east end of Palisade 1 just cutting into the north side of Palisade 2. Palisade 1 averaged $0.45 \mathrm{~m}$ wide and $0.3 \mathrm{~m}$ deep (see sections on illus 17). A short length of narrower palisade trench, apparently blocking the entrance, could not be stratigraphically related to P1/P2.

Finds comprised coarse pottery $(45 / 224,45 / 646)$ from Palisade 2 and fragments of daub and slag. Palisade 2 also produced fragments of burnt bone $(45 / 174,45 / 575,45 / 570)$. Palisade 1 cuts Palisade 2 , both are cut by Ditch 0.

Palisade 3 (P3) This palisade ran southeast from the west terminal of Ditch 0 to meet the north edge of Ditch 1 and Ditch 6, and then followed the course of Ditch 1 eastward. At its west end it stopped abruptly beside Ditch 0 indicating that Palisade 3 was later than, or broadly contemporary with, the former. At its east end, modern disturbance, in the form of a pipe trench running to the south of the modern fence, made interpretation difficult. It is possible, however, that the palisade also respected Ditch 0 at this point. Since the palisade cut off access to the entrance through Ditch 0 , it is likely that it post-dates it. Palisade 3 was ramped on the north side, $1 \mathrm{~m}$ wide and between $0.55 \mathrm{~m}$ and $0.9 \mathrm{~m}$ deep (see illus 13, C). Four segments were excavated (P3/IIV). The trench held closely spaced posts, no more than $0.1 \mathrm{~m}$ apart. The post-pipes noted were of roughly rounded timbers between $0.3-0.4 \mathrm{~m}$ in diameter. The posts had been packed with packing stones in a matrix of redeposited humic sands. The palisade was cut through the upper fills of Ditch 1 at a time when the ditch was totally, or almost totally, infilled. No finds were recovered.

Palisade 4 (P4) This palisade also cut through the totally backfilled Ditch 1, $5 \mathrm{~m}$ to the south of Palisade 3 at their nearest points. The palisade was deepest at the west, surviving to $1.2 \mathrm{~m}$ deep (see illus 13 , $\mathrm{B}$ ). Where the 


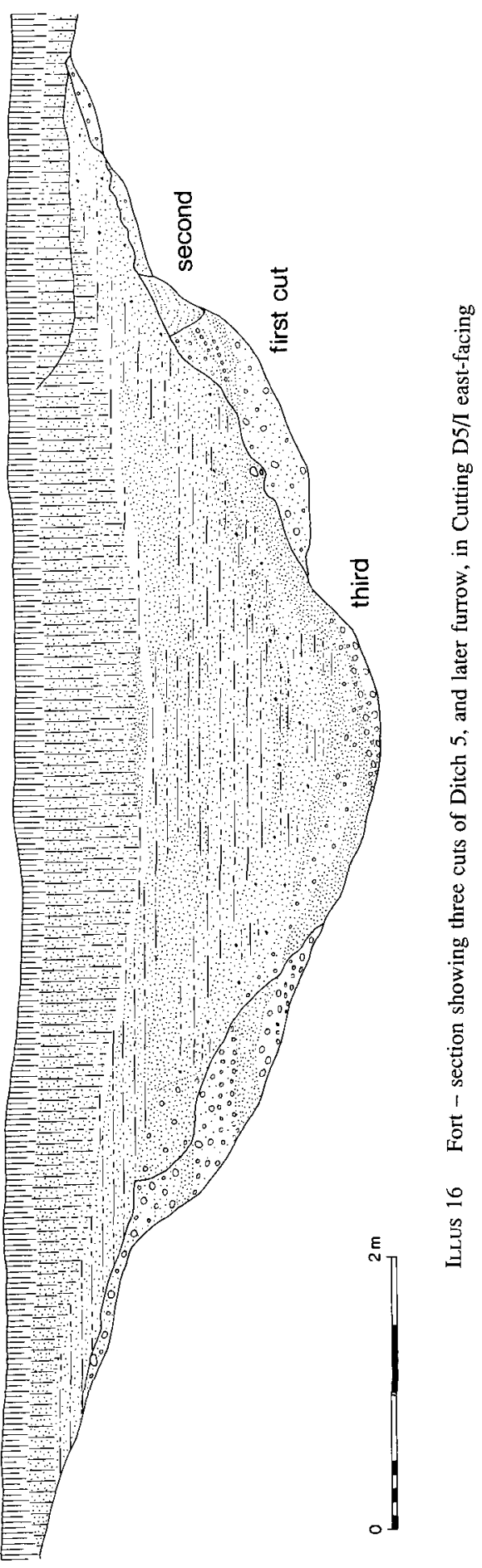


P1
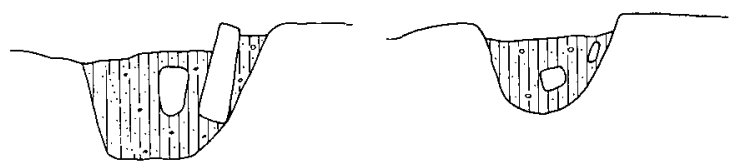

P2
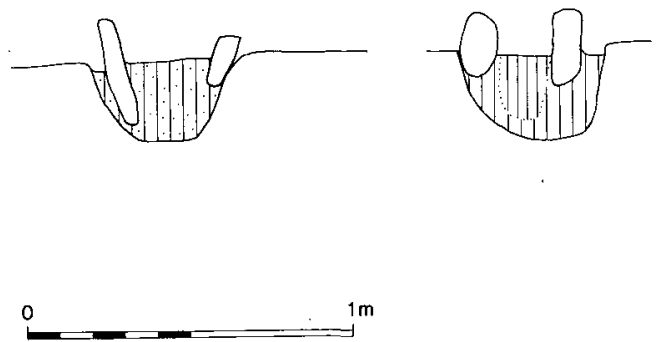
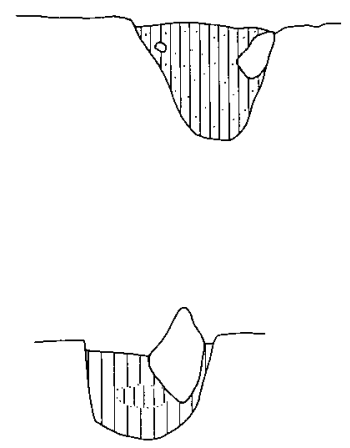

ILLuS 17 Fort - sections of Palisade 1 and Palisade 2; the locations of the section lines are shown on illus 11 , west to east

line of Palisade 4 diverged from the south edge of Ditch 1 (see illus 13, c), however, the depth became progressively shallower towards the east before dying out near the line of the terminals of Ditch 1 - Ditch 4 . This sudden shallowing of $1.2 \mathrm{~m}$ over a distance of $8 \mathrm{~m}$ could have been caused by one of three factors: where the palisade is deepest, the material through which it is cut was the soft fill of Ditch 1 (and the lower fill of Ditch 6); where it shallows it is cut into the firmer subsoil. It is also possible that the palisade was cut to a consistent depth below an original surface which has since been eroded (which would mean that the summit of the promontory originally sloped east/west), or that the palisade rose at an oblique angle over a rampart which no longer exists.

The palisade trench held flat bottomed timber uprights, $0.2-0.25 \mathrm{~m}$ in diameter, in most cases touching and not more than $0.1 \mathrm{~m}$ apart. The posts were packed with redeposited humic sands and some packing stones. A piece of burnt agate or flint (94/137) was recovered from the fill.

Palisade 5 (P5) This is identified as a palisade only by virtue of its surface appearance. It survived as a trench, $1.5 \mathrm{~m}$ in length, truncated to the south by Ditch 6 , ending in a bulbous terminal. It was $0.4 \mathrm{~m}$ wide, the terminal $0.9 \mathrm{~m}$ in diameter, and a maximum of $0.3 \mathrm{~m}$ deep. The profile was U-shaped and filled with banded fine gravels, suggesting a gradual backfilling of an open ditch. The fill was unlike that of an animal burrow and there was nothing to suggest that the feature might have had a domestic or industrial function. No finds were recovered.

Palisade 6 (P6) This palisade was a curvilinear feature lying mostly between Ditch 3 and Ditch 4. It had an ill-defined terminal at its west end in Area 9 and ran from there into Area 10. Near the line of the terminals of Ditch 1 to Ditch 4, it curved north-east and ran across the buttend of Ditch 3, before dying out in the area of heaviest erosion. This showed clearly as a soil mark after the topsoil had been removed but shortly afterwards disappeared as the area dried out and was eroded by wind. A length of the slot was investigated near the terminal of Ditch 3 but by this stage it could not be located to the north of a post-hole near the south edge of the ditch. Here, the slot was only a few centimetres deep. In Area 9, all of the slot was investigated. Here, it averaged $0.4 \mathrm{~m}$ wide and only $0.1 \mathrm{~m}$ deep with a fill of slightly humic silty sand. No evidence of post-pipes was found. The shallowness of the palisade could be explained by its having been cut through a bank associated with Ditch 4 . The palisade produced a sherd of medieval pottery (94/55). 
Palisade 7 (P7) Palisade 7, an almost straight slot immediately south of Ditch 4, ran from an indistinct terminal in Area 9, eastward to a terminal in Area 10 . About $0.4 \mathrm{~m}$ beyond the east of the east terminal was a post-hole. The slot survived as a shallow gully, $0.1-0.15 \mathrm{~m}$ deep, backfilled with a humic sandy loam. No post-pipes were noted. There were no finds.

Palisade 8 (P8) Palisade 8 spanned the breadth of Area 9 and ran into Area 10. It shallowed out to an indistinct terminal $12 \mathrm{~m}$ to the east of the main central baulk, but resumed its course $4 \mathrm{~m}$ to the east, where it curved towards the NNW along the line of the main entrance. It survived to a depth of $0.4 \mathrm{~m}$ in the west half of Area 9. The humic soil fill was removed in spits in an attempt to locate post-pipes. Only two possible examples were noted. In Area 10, the western segment was $0.2 \mathrm{~m}$ wide and $0.35 \mathrm{~m}$ deep at the baulk, becoming shallower towards the east. The curved segment was noted, shortly after topsoil stripping, to run NNW as far as Ditch 4, but, like Palisade 6, soon disappeared in a drying wind. It was generally between $0.6 \mathrm{~m}$ and $0.7 \mathrm{~m}$ wide and $0.35 \mathrm{~m}$ deep. After the northern end of this segment had been eroded during the first few days of excavation, its north limit was defined by a post-hole. A quartzite flake (94/43) and a sherd of medieval pottery (94/44) were recovered. Palisade 8 was cut by Post Alignment 4 .

\section{The antenna slots}

Antenna 1 (A1) This feature was the latest identifiable component of the stratigraphy of the inner defences. Its north terminal respected the eastern butt of Ditch 0, indicating that it was later than the ditch but that the latter was probably still visible at the time of construction. From this point the slot ran SSW over the backfilled features Palisade 3, Palisade 4, Ditch 6, Ditch 8, and Ditch 2, to disappear into the west baulk of Area 9. The slot had an average width of $0.5 \mathrm{~m}$ and a depth of $0.35 \mathrm{~m}$. The fill was a homogeneous sandy loam. The function of this feature was not ascertained. Finds recovered were a flake of coarse pottery (94/56) and a burnt flint flake $(94 / 101)$.

Antenna 2 (A2) This was investigated in the first season. Only a short length survived, running for $3 \mathrm{~m}$ between the western entrance terminal of Palisade 2 and the northern edge of Ditch 0 . Although badly disturbed by animals, it could be seen to be cut by Ditch 0; the northern end did not reach Palisade 2 . The fill was a sandy loam with packingstones, the stones defining at least one post-pipe. The average width was $0.5 \mathrm{~m}$ and depth was $0.3 \mathrm{~m}$. This feature may be the north end of Antenna 4 .

Antenna 3 (A3) This survived only as a very short length of shallow slot, $0.5 \mathrm{~m}$ wide and a maximum of 0.1 $m$ deep, between the east entrance terminal of Palisade 2 and Ditch 0. Four packing stones survived in the fill of sandy loam. A shallow depression in the subsoil may represent a post position like those noted in Palisade 2. Antenna 2 and Antenna 3 may be the remains of an entrance passage associated with the entrance through Palisade 2.

Antenna 4 (A4) This short length of palisade slot was located near the entrance through Ditch 1. It ran NNW from a point to the east of Palisade 3, over the backfilled Ditch 1. Its north terminal was not located in Area 10 but it may be that this is represented by Antenna 2. The slot, V-sectioned and steepsided, $0.4 \mathrm{~m}$ deep and $0.6 \mathrm{~m}$ wide, has held a stone-packed palisade. The stone packing was in a matrix of sandy loam, and three post-pipes, each $0.3 \mathrm{~m}$ in diameter and $0.3 \mathrm{~m}$ apart, were located. A fragment of daub or furnace lining (94/ $108)$ and a sherd of medieval pottery $(94 / 107)$ were found in the upper fills.

Antenna 5 (A5) This lay to the east of Antenna 4. It consisted of a short length (c $8 \mathrm{~m}$ ) of palisade trench, with indistinct ends and edges. It was very badly disturbed by animal burrows which had followed its course. Its maximum depth was $0.4 \mathrm{~m}$; width $0.8 \mathrm{~m}$. 


\section{The post alignments}

Post Alignment 1 (PL1) Five negative features form a line running east/west immediately to the south of, and parallel to, Ditch 3. The features were an average of $1.5 \mathrm{~m}$ apart, and measured an average of $0.50 \mathrm{~m}$ in diameter with depths between $0.16 \mathrm{~m}$ and $0.29 \mathrm{~m}$. It is possible that the line represents posts associated with either Ditch 3 or Ditch 4.

Post Alignment 2 (PL2) About $3 \mathrm{~m}$ north of Ditch 5, and beginning north of its 'terminal', was a line of regularly spaced negative features. Seven features were noted in the original Area 10, and in an extension to the east, two more were found on the same line and spacing $(\mathrm{c} 2.4 \mathrm{~m})$. To the east of this line was a line of six paired features. All the features had similar sandy loam fills and were an average of $0.5 \mathrm{~m}$ in diameter and between 0.1 and $0.35 \mathrm{~m}$ deep.

Post Alignments 3 \& 4 (PL3 \& PL4) Running approximately north/south in the space between Ditch 2 and Ditch 3, was a line of nine negative features (Post Alignment 3). A further line, Post Alignment 4, starting from a point on the inner lip of Ditch 5 and running northeast then NNE, is probably a continuation of Post Alignment 3. Narrow trenches in the wide baulk between Areas 9 and 10 were opened to investigate the two lines. In Area 9, to the north of Ditch 5, the irregular line consisted of 29 small negative features. Continuing the line, in a trench in the baulk, were a further 8 features. Between this stretch and Post Alignment 3 no definite line was located, but two features, one cutting the fill of Ditch 3, may belong to the line. The features had average diameters of $0.25 \mathrm{~m}$ and were between $0.10 \mathrm{~m}$ and $0.29 \mathrm{~m}$ deep.

\section{The interior}

\section{House 1}

A large part of the surviving summit plateau within the defences was occupied by a large ring-groove house. The house comprised four main elements; the ring-groove, an inner post-ring, a complex entrance, and a possible outer post-ring (illus 18 \& illus 19).

The ring-groove An almost perfect circle enclosing an area $14.4 \mathrm{~m}$ in diameter, the ring-groove held a timber wall constructed of closely set, round log uprights. In section, the dimensions of the groove were similar to those of the inner palisades, being $0.3-0.5 \mathrm{~m}$ wide and $0.3-0.5 \mathrm{~m}$ deep (illus 20). Post-pipes were recognized at several points in the circumference, the longest stretch to the NNE. Here, a lower fill of lighter sandy loam clearly showed the lower $0.15 \mathrm{~m}$ of 13 post-shadows, mostly round sectioned and between $0.18 \mathrm{~m}$ and $0.30 \mathrm{~m}$ in diameter. The largest was oval in section and measured $0.3 \mathrm{~m}$ by $0.48 \mathrm{~m}$. The distance between the posts varied from $0.1 \mathrm{~m}$ to $1.1 \mathrm{~m}$, the larger gaps probably originally filled with posts not identified by excavation. The posts were packed with medium and large stones in a matrix of humic sandy loams. The packing stones showed various patterns: in some lengths of groove, they were found only on the outer edge, packing the posts against the inner face; in some stretches they were found on both faces.

A gap in the ring-groove $2.7 \mathrm{~m}$ wide indicated the position of the doorway into the house. Charcoal from a post-pipe in the north terminal, identified as small diameter oak roundwood, gave a radiocarbon date of 2445 $\pm 60 \mathrm{BP}$ (uncal) (GU1655). Finds from the groove were late Bronze Age or Iron Age coarse pottery (45/107, $45 / 115,45 / 121,45 / 226,45 / 248,45 / 460)$ and fragments of slag and daub. Burnt animal bone was also recovered (45/ 178, 45/243, 45/247, 45/407, 45/541, 45/554, 45/569, 45/478, 45/92, 45/181, 45/485, 45/416).

Internal post-ring The internal post-ring was $11 \mathrm{~m}$ in diameter. Thirteen post-holes (F1 F13) survived, mostly in the south-west sector, with those to the north-east slightly off the line of the circle. All were very shallow, no more than $0.22 \mathrm{~m}$ deep, with an average diameter of $0.5 \mathrm{~m}$ (illus 21). Twelve of the post-holes contained packing stones, some of which have collapsed to form piles of flat stones. This, and the lack of identifiable post-pipes, may suggest that the posts had been deliberately removed. The missing post-holes can be explained 


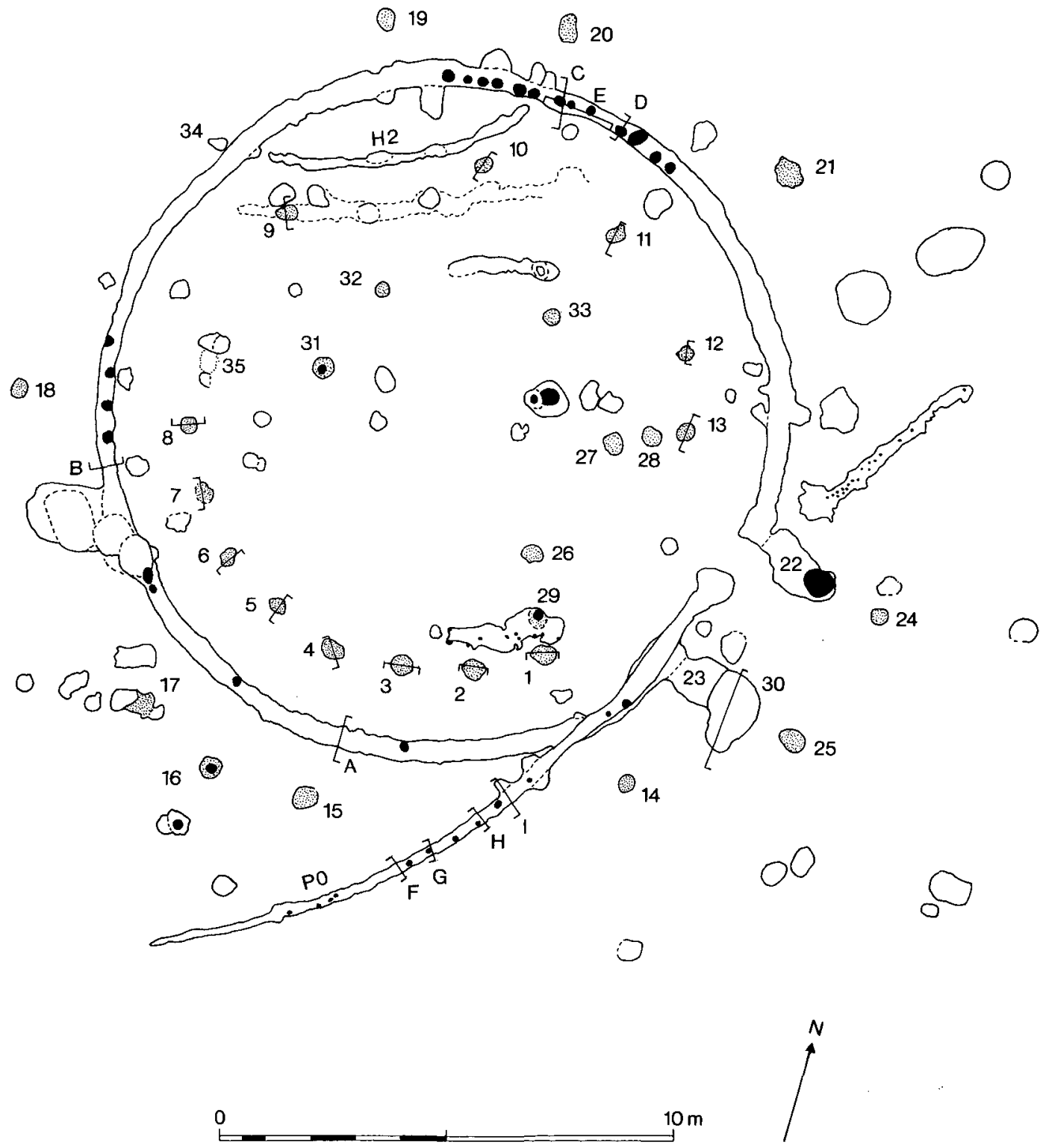

ILlus 18 Fort - plan of House 1 (and House 2) showing F-numbers - some negative features near the edge of the area have been excluded

by the shallowness of the features allied with an undulating subsoil surface. The eight post-holes to the southwest were $1.5 \mathrm{~m}$ apart, centre to centre, or roughly $16^{\circ}$ apart. If this was the average angle then two post-holes are missing between F8 and F9 (although the gap here is greater than $48^{\circ}$ ), two between F9 and F10, one between F10 and F11, and one between F11 and F12. F1 is $20^{\circ}$ south of a radial line drawn from the house centre to the south doorpost. F13 is about $20^{\circ}$ north of a similar line drawn to the north doorpost. It is possible, therefore, but not necessarily the case, that there may be post-holes missing between F13 and F1 (see entrance 


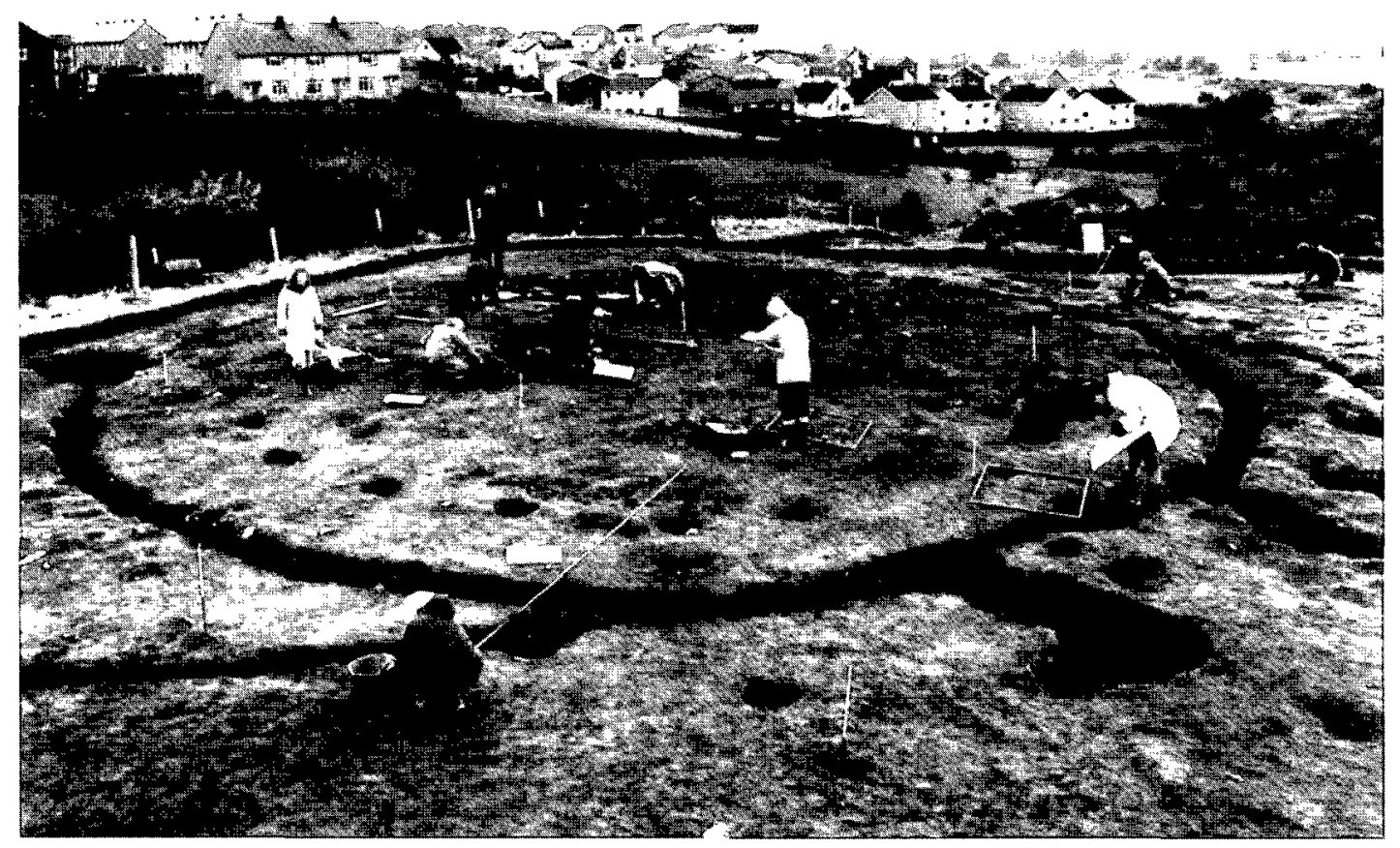

ILLUS 19 Fort - House 1 under excavation with Bannockburn village in the background, from the south

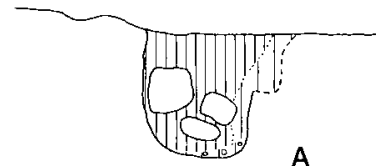

A

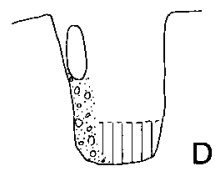

0

ILLus 20 House 1 - sections of the ring-groove numbered as on House 1 plan (illus 18); section 5 shows an axial section of three post-pipes (post-pipe fills removed) at a point where the packing soils change character 

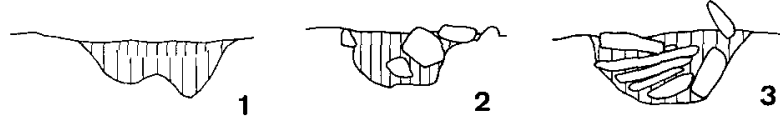

3

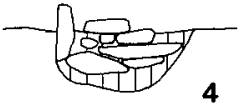

4

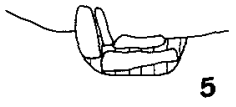

5
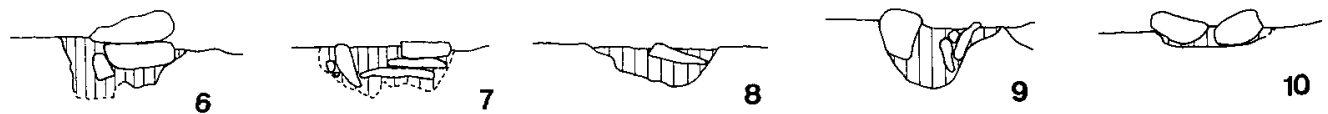

13
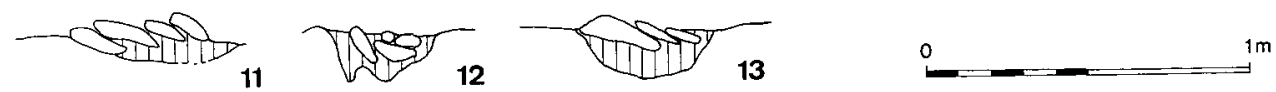

ILLUS 21 House 1 - sections of inner post-ring post-holes F1 to F13

description). If no posts are missing between F13 and F1, then there were probably 19 posts in the ring. The wider gap between F8 and F9 could be explained by its position opposite the doorway. If there were 19 posts, arranged about an axial line of symmetry from the centre of the doorway through the centre of the circle, then the line would run through the tenth post (see Guilbert 1982). This would have been about $19^{\circ}$ from F9 and $19^{\circ}$ from the other missing post-hole (which was probably about $16^{\circ}$ from F8). Apart from worked stone from F4 (45/188), the only finds from the post-ring consisted of slag and clinker. F13 produced a fragment of burnt cattle bone $(45 / 406)$

Entrance A porch structure protruded from the terminal posts at the entrance gap in the ring-groove. The northern element was better preserved. Here, a relatively shallow groove (F22), $0.8 \mathrm{~m}$ wide and $0.35 \mathrm{~min}$ maximum depth, protruded $2.4 \mathrm{~m}$ southeast from the groove terminal. It had been cut in a separate and later operation from the wall groove. At its southeast end was a post-pipe of a large post measuring $0.7 \mathrm{~m}$ by $0.6 \mathrm{~m}$. The southern part of the porch had been disturbed. The southern groove terminal had been cut by a light fence slot (Palisade 0), and the southeast end of the porch groove (F23) had been cut by a fire pit (F30, illus 22). Charcoal from the fill of the fire pit was sampled for radiocarbon assay. The charcoal, identified as mostly oak with one piece of hazel, gave a date of $2255 \pm 60 \mathrm{BP}$ (uncal) (GU-1656). Fire pit F30 produced coarse pottery

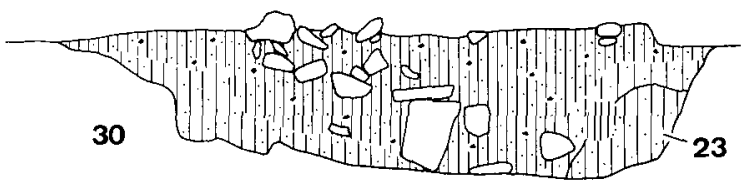

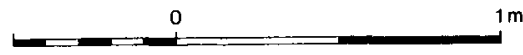

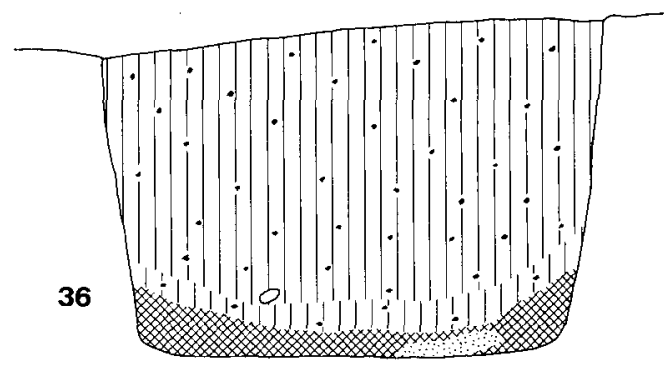

Illus 22 House 1 - sections of features F30 and F36 as marked on illus 18 and illus 11 respectively 


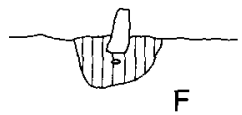

F

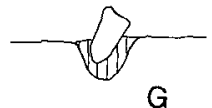

G

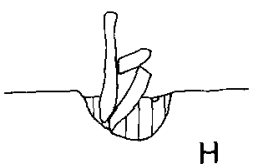

$\mathrm{H}$

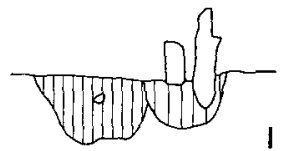

I

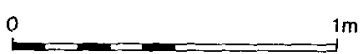

ILLUS 23 Fort - Palisade 0 sections, west to east as marked on illus 18

(45/532), a flint flake and chalcedony flake (45/534) and fragments of burnt animal bone (45/465, 45/533). F22 produced fragments of cattle bone $(45 / 75,45 / 251)$.

Continuing the line of the porch $1.2 \mathrm{~m}$ outwards were two post-holes (F24 \& F25). A line drawn from F24 inwards along the north porch groove meets with a post-hole (F27). Mirroring this on the south side of the doorway was a post-hole (F26). The four posts F24-F27 form a rectangle $3.3 \mathrm{~m}$ wide and $7 \mathrm{~m}$ long which appears to have been part of the entrance complex. Their existence could explain the lack of internal post-ring post-holes in the entrance area. Further symmetry was noted in two post-holes, F28 and F29, which lie between F13 and F27, and F1 and F26 respectively. F29, however, is closer to F1 than F28 is to F13. F28 produced slag; F29 some slag.

Outer Post-ring During excavation, an outer post-ring was postulated but, because there were few features which could be part of such an element, the hypothesis was thought to be not proven. The idea was revived after the discovery of the outer post-ring in the house in Homestead 1. This house was almost identical in size to House1. If a circle is drawn, concentric to the ring-groove and passing through the outer end of the porch grooves, the line passes through eight features (F14-F21). It is possible that some or all of these represent the surviving post-holes of an outer post-ring $18 \mathrm{~m}$ in diameter. Finds included slag from F14, F15, F16 and F17. All were tiny fragments recovered during flotation of soil samples.

Also postulated during excavation was a further post-ring, inside the line of the internal post-ring mentioned above. It is interesting to note that, of the many post-holes not obviously associated with the structure of House 1, three sit on the line of a circle concentric with the wallgroove, and c $6 \mathrm{~m}$ in diameter (F31, F32, F33). F33 produced a sherd of coarse pottery (45/410).

\section{Palisade $0(P 0)$}

Cutting the wall groove of House 1 was a palisade trench (Palisade 0) of lighter construction than Palisade 1 to Palisade 8 - more a light fence than a palisade (see illus 23 for sections). An entrance through Palisade 0 overlapped with the house entrance, $1.9 \mathrm{~m}$ to the northeast of it. The entrance, $2.1 \mathrm{~m}$ wide, was defined by two bulbous terminals; no post-pipes were noted in the terminals but in the palisade slots to each side of the entrance, stakesized post-shadows, up to $0.15 \mathrm{~m}$ in diameter, were noted in the sandy loam and packing-stone fill. To the south of the entrance, the slot, $0.25 \mathrm{~m}$ wide, ran for $14.3 \mathrm{~m}$ south-west before dying out near the top of the west flank of the promontory. To the north, the slot was $0.30 \mathrm{~m}$ wide and $\operatorname{ran} 4.6 \mathrm{~m}$ northeast before dying out near the east flank. The palisade produced fragments of coarse pottery $(45 / 227,45 / 250,45 / 409)$, a saddle quern (45/414), fragments of burnt animal bone $(45 / 225,45 / 179,45 / 352,45 / 390,45 / 561)$ and slag and clinker.

\section{House 2}

In the north quadrant of House 1, a shallow arc of groove may represent the southern side of a second house, House 2 ( $\mathrm{H} 2$ on illus 18 ). The relationship of the groove to that of House 1 could not be established. The groove was shallow, less than $0.1 \mathrm{~m}$ deep, and ran for $6.6 \mathrm{~m}$ inside the line of 
$\mathrm{H} 1$ groove. Its original diameter would have been similar to that of $\mathrm{H} 1$ groove, but no other features, such as elements of post-rings, could definitely be associated with it. A small, shallow feature (F34) outside $\mathrm{H} 1$ groove appears to continue the line of $\mathrm{H} 2$ groove. That the latter was the south side of a second house, and that close to the present top of the north flank, suggests that a large area of the north end of the promontory has been eroded away.

\section{Interior miscellaneous features}

Within the area defined by the defences (Palisade 0 excluded) were a large number of negative features not obviously associated with Houses 1 and 2, and which do not appear to form any pattern. These number 130 when features of definite modern date have been excluded. Most of these features have no known function, being pits of various sizes and depths, with no distinguishing features. The exceptions were two pits (F30 \& F35) which contained material to suggest that they were fire pits or hearths, as well as 38 definite, and six possible post-holes (three of which may belong to an innermost post-ring of $\mathrm{H} 1$ ). The only other feature worthy of mention here was F36 (illus 22), a large deep pit which produced two radiocarbon dates: (GU-1645) $940 \pm 60$ $\mathrm{BP}$ and (GU-1657) $975 \pm 60 \mathrm{BP}$ ). The pit also produced a flint flake (45/706), and slag and daub. F36 is discussed in greater detail in 'Radiocarbon dates : assessment' (below). F35 produced a fragment of coarse pottery (45/ $571)$. Other pits produced coarse pottery $(45 / 229,45 / 422)$, flint flakes $(45 / 284,45 / 504)$ and a sandstone cobble (45/628). Miscellaneous post-holes produced a sherd of medieval pottery $(45 / 411)$, a flint flake (45/196) a saddle-quern (45/412), an iron object (45/697) and a burnt cobble (45/519).

\section{FORT EXTERIOR}

Beyond the line of Ditch 5, to the south, and in the line of the main approach to the fort, were two houses, the later superimposed on the earlier (illus 24), and two four-post settings.

\section{House 3}

The earlier of the two houses, House 3, consisted of two elements: a wall-groove and an internal post-ring. The wall groove, $9.8 \mathrm{~m}$ in diameter, had an entrance to the southeast, defined by two bulbous terminals. The groove was shallow, $0.15 \mathrm{~m}$ deep, and where it has subsequently been eroded by a medieval furrow to the north, it existed as no more than a shadow in the subsoil. The average width of the groove was $0.15 \mathrm{~m}$ (illus 25). No post-pipes were identified. Only three post-holes of the internal post-ring survived; all were shallow, less than $0.15 \mathrm{~m}$ deep, and the missing post-holes would have been in an area affected by a second furrow. The original number of posts (nine) in the ring can be estimated by comparison with the more complete post-ring of House 4 . The post-ring would have been about $5.2 \mathrm{~m}$ in diameter. A sherd of medieval pottery (94/148) was recovered from the wall-groove.

\section{House 4}

House 4 was similar in size to House 3 , and was constructed $0.9 \mathrm{~m}$ further NNW than the former. The wall slot, $10 \mathrm{~m}$ in diameter, was more substantial than that of House 3, being between $0.2 \mathrm{~m}$ and $0.4 \mathrm{~m}$ wide and between $0.15 \mathrm{~m}$ and $0.3 \mathrm{~m}$ deep. Part of its circuit, to the north, has been removed by the medieval furrow, at its deepest point. Like the wall slot of House 3, two bulbous terminals defined a doorway to the southeast, and no post-shadows were noted. All of the internal post-ring survived. It was $5.5 \mathrm{~m}$ in diameter and consisted of nine post-holes of an average diameter of $0.35 \mathrm{~m}$, and ranging in depth between $0.15 \mathrm{~m}$ and $0.35 \mathrm{~m}$ (illus 25 ). 


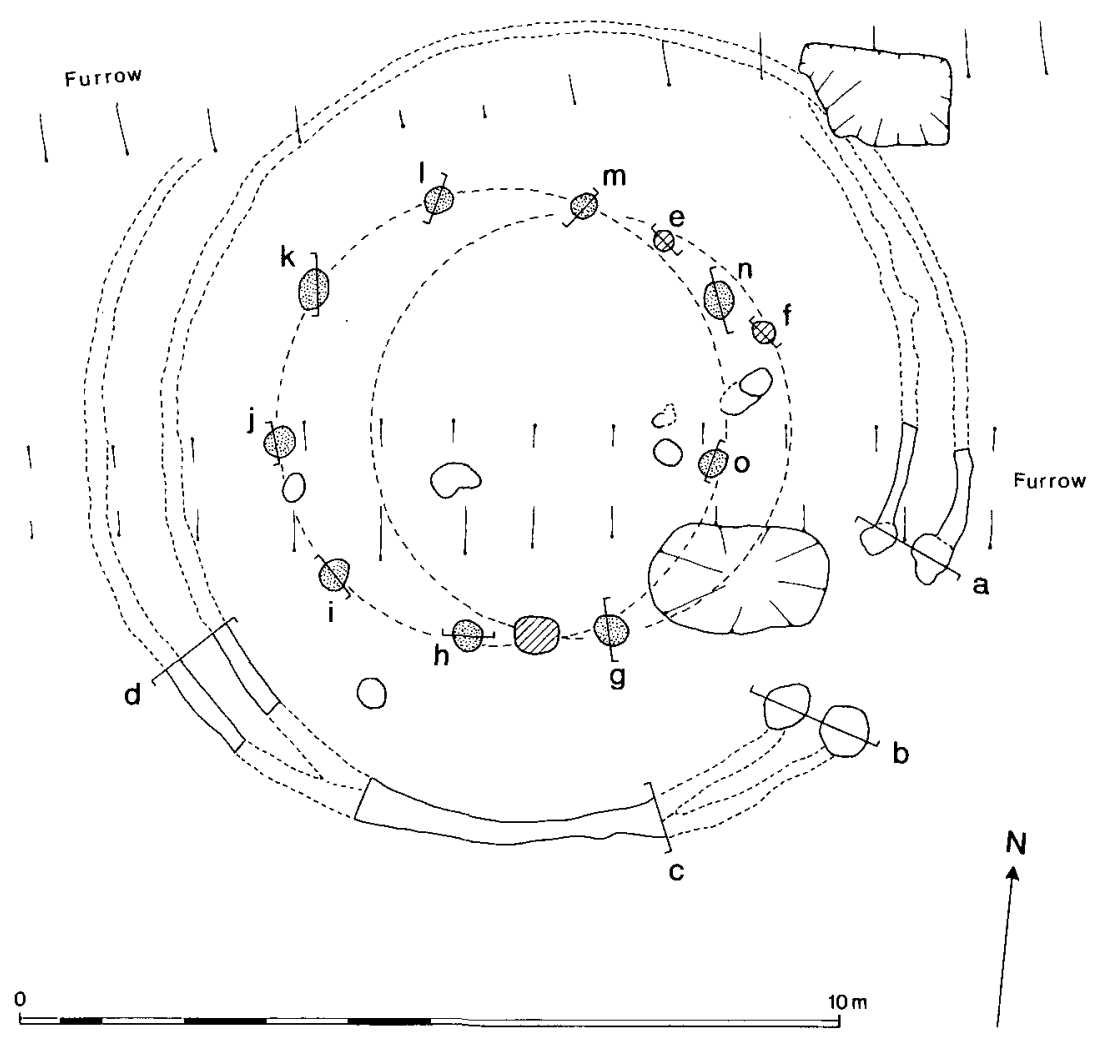

Illus 24 Fort - plan of House 3 and House 4; House 3 post-ring post-holes are hatched; House 4 post-ring post-holes are stippled; the sections are on illus 25

\section{Four-posters}

The southern of the two four-post settings (FP1) was the smaller. The four negative features were $0.5 \mathrm{~m}$ in diameter on average, and $0.32 \mathrm{~m}$ to $0.43 \mathrm{~m}$ deep, with homogeneous fills of loamy sand. On plan, they formed a rhomboid with sides of $1.8 \mathrm{~m}$, centre of feature to centre of feature. The other setting (FP2), $2 \mathrm{~m}$ to the NNW, was larger and squarer, with sides $2.1 \mathrm{~m}$ long. The negative features were $0.3-0.4 \mathrm{~m}$ in diameter and $0.12-0.24 \mathrm{~m}$ deep, with fills of loamy sand (illus 26). It should be noted that, although these are described as four-posters, none of the features showed post-shadows or stone packing defining a post position.

\section{Plateau miscellaneous features}

In the area of the defences, and beyond them, were a large number of negative features which, like those in the interior, could not be associated with obvious patterns such as houses or post alignments. Here, however, these features were mostly less well preserved than the internal miscellaneous features, most surviving as small, very shallow, featureless pits. Indeed, of the 114 wholly or partially excavated, only three could be identified as post-holes, and a further six as possible post-holes (not all of the negative features noted and planned were investigated). Two of the post-holes cut the wholly backfilled Ditches 1 and 2. One of the miscellaneous pits produced medieval pottery $(94 / 102)$. 

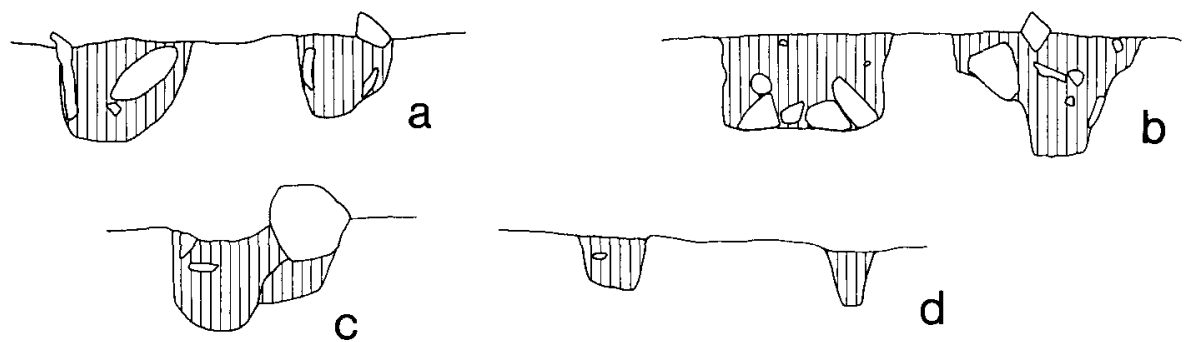

d

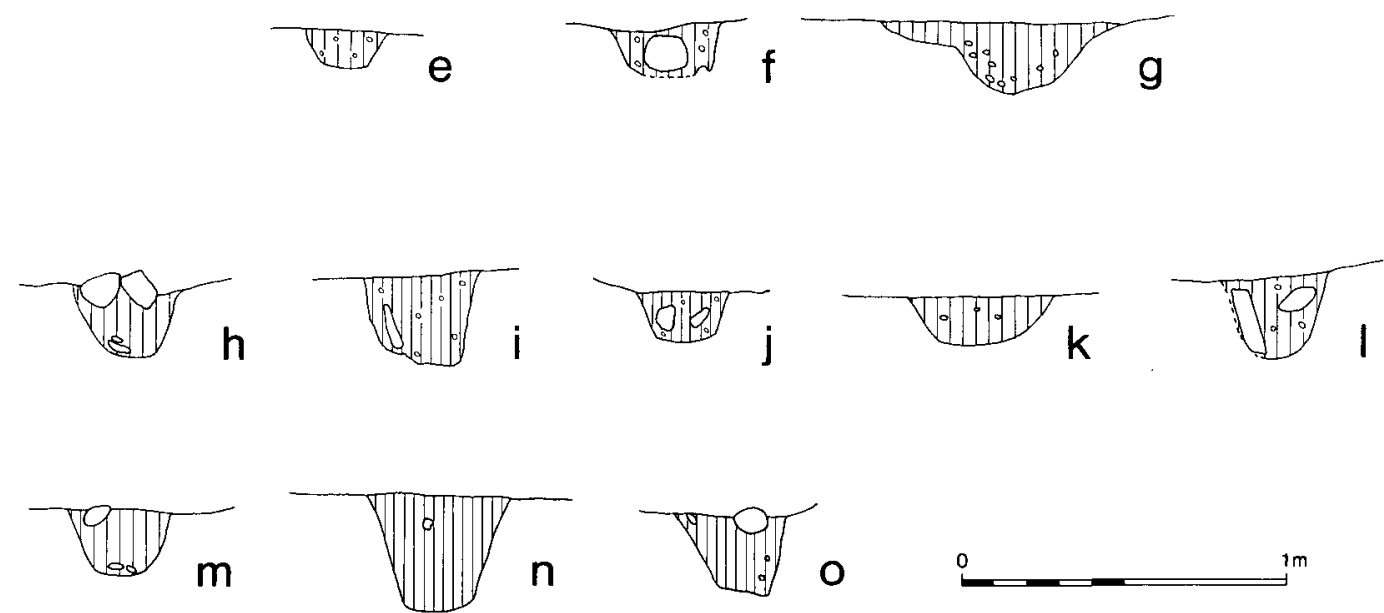

Illus 25 House 3 and House 4 sections as located on illus 24; (a) to (d) are ring-groove sections; (e) and (f) are House 3 post-holes; (g) to (o) are House 4 post-holes

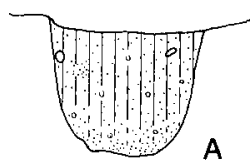

A

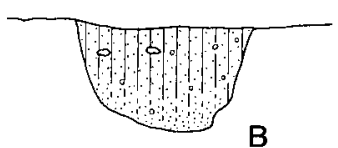

$B$

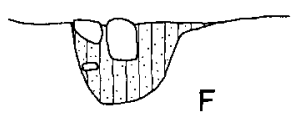

E

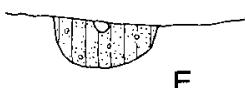

$F$

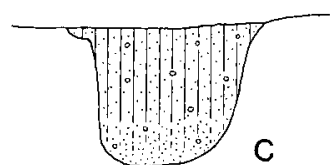

C

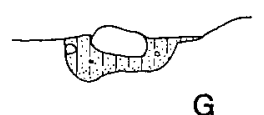

G

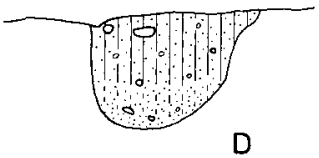

D

0 $1 \mathrm{~m}$

ILLus 26 Fort - sections of the four-post structures as marked on illus 12 
Most of the features, including short linear features, could be assigned neither function nor date. Exceptions include features of apparently considerably later date. At the south ends of Areas 9 and 10, parallel shallow gullies running east/west across the promontory are probably the result of medieval or later rig-and-furrow cultivation. Similar cultivation marks were found in the area of the pit and post enclosures (Rideout forthcoming). Also at the south ends of Areas 9 and 10, was a rough line of irregular, ill-defined, shallow pits. One of the pits produced a sherd of medieval pottery (94/156). These appear to be tree-root holes associated with a field boundary marked on the OS 1st edition 6-inch map (Stirling Sheet XVII, 1865, surveyed 1860).

\section{SLOPES}

\section{West slope : Area 2}

Area 2 was a narrow trench ( $2 \mathrm{~m}$ wide) designed to investigate the west flank of the promontory, in the meadow/ scrub field. It ran $32.5 \mathrm{~m}$ westwards from the south-west corner of Area 1. The whole of the east end of the trench (top of the slope) was disturbed by modern pits, apparently excavated for sand extraction earlier this century (local information). As a result, any expected continuation of Ditch 0 , and possibly Ditch 1 , around the west flank of the promontory, had been removed. This upper part of the trench had a relatively shallow slope. There were no archaeological features for $4 \mathrm{~m}$ to the west of the modern disturbance. From here, however, the slope steepened sharply as a result of defensive activity. Four distinct phases of defence could be identified. A scarp, rather than a ditch, had been cut into the hillslope, had backfilled, and had then been recut. Several stake-holes cut the base of this scarp, and the subsoil slope below it. The stake-holes entered the subsoil at angles varying from horizontal to about $45^{\circ}$ above horizontal. They appear to have formed a light chevaux de frise.

At some stage after the recut had infilled, a narrow ditch was cut. The relationship between this ditch and a broad ditch to the west is uncertain. The uppermost fill of the broad ditch contained 14th-century medieval pottery (45/253). Excavation and recording, of the lower defences was hampered by waterlogging. The narrow ditch fill produced coarse pottery (45/257) and a fragment of burnt bone (45/258).

The defences in this trench could not be linked to the ditches, or ditch sequences, elsewhere on the site.

\section{North slope: Area 3}

This trench, $32.5 \mathrm{~m}$ long, ran north from the north-west corner of Area 1. Most of the trench exposed two large areas of modern disturbance consisting of a large number of pits near the top of the slope, and a very large quarry, probably for sand, near the bottom of the trench. One of the modern pits produced a piece of jet (45/ 129). With the exception of the very top and very bottom, the rest of the trench was archaeologically sterile. At the top were four negative features which may belong to the period of the fort. One of them, a post-hole, produced a flint flake (45/199). They are described with the Internal Miscellaneous features of Area 1 (in archive). At the bottom of the trench, below the modern lynchet, the subsoil appears to have been deliberately scarped. This may be the start of defences to the north which were not excavated by the CEU. A sherd of coarse pottery (45/51) and a sherd of medieval pottery (45/53) were recovered from the A-horizon. Medieval pottery was also recovered from modern hillwash (45/97), the lynchet near the end of the trench (45/114) and a modern pit (45/135). The hillwash also produced a flake of flint or chert $(45 / 82)$. Modern pits produced an iron object (45/113) and a fragment of copper alloy sheet (45/127).

\section{East slope}

1982: Area 4 Area 4 ran east from the northeast corner of Area 1. The western end of the trench, the upper slopes, was $16.5 \mathrm{~m}$ long and $2 \mathrm{~m}$ wide. To the east of this, the central part of the trench was expanded to a final size of $13.5 \mathrm{~m}$ east/west by $10 \mathrm{~m}$, to investigate the defences on the lower flanks. The eastern end of the trench, $15.5 \mathrm{~m}$ long and $4 \mathrm{~m}$ wide, crossed the bog; only the easternmost end was excavated below turf level, to provide a peat monolith for pollen assessment. No archaeological features were noted on the upper slopes, 
due, probably, to heavy erosion. On the lower slopes, the extremely unstable nature of the waterlogged soils, natural and archaeological, made excavation difficult at best, and hazardous at worst. As a result, only the upper defences could be investigated to any great degree.

In the expanded area, after removal of modern topsoil and featureless hillwash, the lower parts of several ditches were noted. These were excavated in five cuttings at intervals of $0.5 \mathrm{~m}$. Even over such short distances, with no more than $2 \mathrm{~m}$ between sections, it was impossible to definitely follow all ditch cuts from one section into another. However, enough was revealed to suggest that, in the upper defences at least, there were seven cuts and recuts. The lower defences, where they ran into the bog, could not be properly investigated. A machine trench cut into the bog showed that the defences interbedded with bog growth, and that sand layers in the bog were probably associated with defence cutting activity. The section revealed by the machine cutting, however, could not safely be recorded except by photography; the sides collapsed within less than a half hour of opening.

A large, worked oak timber (F474), apparently from one of the ditches, gave a date of (GU-1652) $2920 \pm 60 \mathrm{BC}$. A later feature, a large, shallow pit, cut the innermost edge of the area of defences.

The defences produced flaked siltstone (45/577), late Bronze or Iron Age coarse pottery $(45 / 255)$, and pottery from two probably Neolithic vessels $(45 / 579,45 / 580,45 / 586$ and $45 / 5878)$ and quartz flakes (45/527, $45 / 528)$. Burnt bone fragments were also recovered $(45 / 259,45 / 254,45 / 367,45 / 139,45 / 186,45 / 507)$. The A-horizon in Area 4 produced medieval pottery $(45 / 166,45 / 169)$ and flint flakes $(45 / 19,45 / 167)$. Unstratified finds from Area 4 included coarse pottery (45/573).

Area 4 was 2.5 morth of Area 8.

1982: Area 5 Area 5 was a trench $16 \mathrm{~m}$ long by $1 \mathrm{~m}$ wide, running east/west immediately to the north of the modern fence and to the east of the southeast corner of Area 1. The upper (western) end of the trench was later subsumed by Area 8 . The trench revealed a number of linear features, most obvious being a ditch which appears to be the same as Ditch 2 in Area 10. This ditch was later than another, further downslope. The upper slope showed the vestigial remains of ditches or grooves, mostly eroded away. A quartz flake (45/661) was recovered from the hillwash overlying the ditches.

1982: Area 6 Area 6 was an irregularly shaped trench, $4 \mathrm{~m}$ north of Area 5, designed to follow the defences found in Area 1. At the west end of the trench, Ditch 0 survived to a depth of $0.25 \mathrm{~m}$ and a width of $1.10 \mathrm{~m}$, obviously severely truncated by erosion of the upper flank. To the east of Ditch 0 was a possible palisade groove. At the east end of the trench, a large pit was located and the trench was expanded to investigate it. The pit was not fully investigated but it proved to pre-date a defence scarp which represents the inner edge of the main area of defences on the lower slopes. A recut in the large pit produced coarse pottery (45/635), flint $(45 / 709,45 / 712)$, a shattered quartz pebble (45/638) and a fragment of burnt bone (45/636). The fill of the original pit also produced a fragment of burnt bone (45/639). The A-horizon in Area 6 produced a flake of coarse pottery (45/47).

1982: Area 7 Area 7 was a small trench, $5.3 \mathrm{~m}$ long by $1 \mathrm{~m}, 4 \mathrm{~m}$ north of Area 6 . Like Area 6 it was designed to follow the defences on the summit. Here, Ditch 0 survived to a width of $1.05 \mathrm{~m}$ and a depth of $0.25 \mathrm{~m}$. Excavation of the larger area, Area 8, in 1985 showed that Ditch 0 died out a little to the north of this point. A second feature in Area 7 may have been the continuation of the possible palisade groove in Area 6.

1985: Area 8 This area, roughly $17 \mathrm{~m}$ north/south by $40 \mathrm{~m}$, subsumed Areas 6 and 7, the upper end of Area 5 , and a narrow strip of Area 1 . The lower part of the area became very boggy, the final $5 \mathrm{~m}$ or so being flooded and unworkable. Very disturbed soils on the upper slopes made it difficult to see features. The opening of Area 8 added little to the information from Areas 5 to 7.

Hillwash produced coarse pottery $(94 / 92,94 / 96)$, medieval pottery $(94 / 110)$ and slag. A ditch fill F3120 produced coarse pottery $(94 / 94,94 / 98,94 / 133)$. The A-horizon produced a sherd of medieval pottery $(94 / 49)$.

1985: Area 10 flank In the north-east corner of Area 10, and for some distance along the east side, was an area of accumulated soils within which the east terminals of the defences from Ditch 6 outwards were expected to be found. Ten trenches in this area revealed the east terminals (probably) of Ditches 2 and 3, a small ditch 
where the east terminal of Ditch 4 was expected, a palisade (P9), and a relatively recent fence line. The east terminal of Ditch 3 showed as two separate ditches, indicating that a recut had been made on a different line to the original. Both cuts could only be traced for $16 \mathrm{~m}$ north from the terminals. Ditch 2 was followed for only $6 \mathrm{~m}$.

\section{ARTEFACTS DISCUSSIONS}

Artefacts were recovered by two methods: as small finds on site, and from flotated bulk soil samples. All but a few of those recovered from samples were tiny crumbs (of slag, daub and pottery, for instance) and, therefore, they are mostly ignored here. Slag and daub recovered on site is also referred to only in the context descriptions. The catalogues can be found in the microfiche section.

THE COARSE POTTERY (TABLE 6, FICHE 1/B3-B11)

\section{J McLellan with Ann MacSween \& Jenny Lee}

The pottery from Bannockburn represents three different assemblages. From the 1982 season are several sherds which appear, from their decoration and morphology, to pre-date the main phase of the site, and are probably Neolithic. The sherds, found in one of the ditch cuts in Area 4, represent two vessels. One $(45 / 579,45 / 580,45 / 586$, illus 27$)$ has a slight $S$-shaped profile and a pedestal base. From the sherds which survive, it was probably a small vessel, the estimated rim diameter being 105 $\mathrm{mm}$ and that of the base $90 \mathrm{~mm}$. The exterior, which was probably slipped, is decorated with incised decoration, parallel lines and a 'basket-weave' pattern under the rim, and herring-bone decoration above the base. The second vessel $(45 / 587,45 / 588$, illus 27$)$ is represented by a rolled, everted rim and a carinated sherd, and is undecorated.

The remainder of the pottery from the 1982 season comprises about 50 sherds, presumably late Bronze Age or Iron Age. Many are abraded body sherds, small fragments or surface flakes, too small to allow the identification of vessel shape. A few of the sherds are slipped, but none is decorated. There are two rims (45/58 \& 45/168, illus 27), both plain, and a further sherd from the flat part of a base (45/84), but neither of these is diagnostic of vessel type. A very fine clay was used, with the larger vessels being tempered with rock fragments. The temper, which comprises about $10 \%$ of the whole, has been finely ground. Most of the sherds are incompletely oxidized, either red or brown with a grey core. The method of manufacture was coil construction.

The vessels from the 1985 season are different to the above two groups. There are 40 sherds and fragments as well as almost a third of a vessel (94/126, 94/155, illus 28). They are much coarser than the vessels from the 1982 season and their thickness indicates that they are probably from large vessels. The sherds are almost always slipped on the exterior and occasionally on the interior as well. The rim sherds represent inverted or plain lips. The added temper comprises $20-30 \%$ of the whole, and the average size of the inclusions is greater, many over $10 \mathrm{~mm}$ in length. The vessel shapes are very similar to the Iron Age vessels from other late Iron Age Lowland hillfort sites such as Hownam Rings (C M Piggott 1948), Broxmouth (Cool 1982), and Kaimes (Simpson 1969).

Only five sherds were recovered from Homestead 1. They are more akin to the later pottery from the 1982 season than that from the 1985 season, but the sherds are very small. One of the sherds is a rim sherd, a beaded rim with possible incised decoration below it $(60 / 26$, illus 27). 


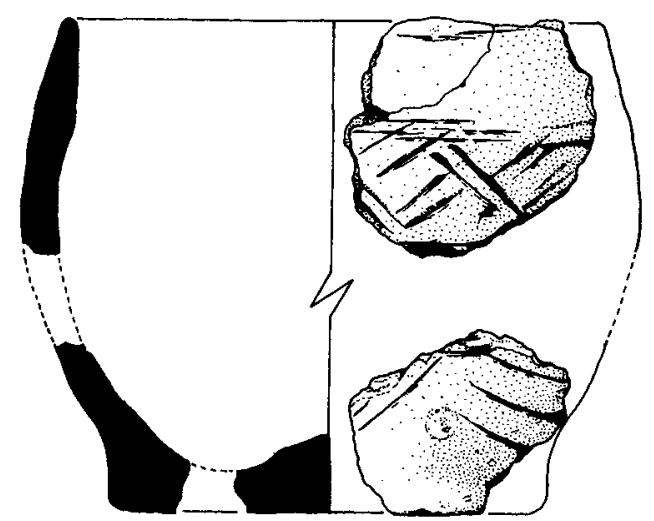

$45 / 579,580,586$

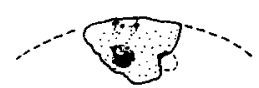

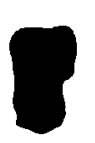
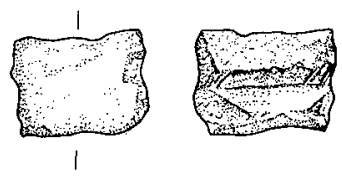

$60 / 26$
0

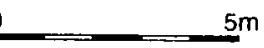

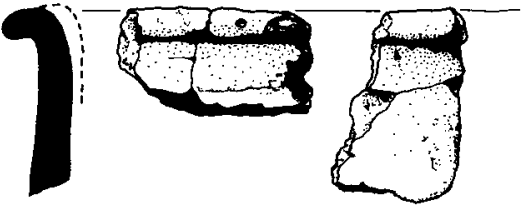
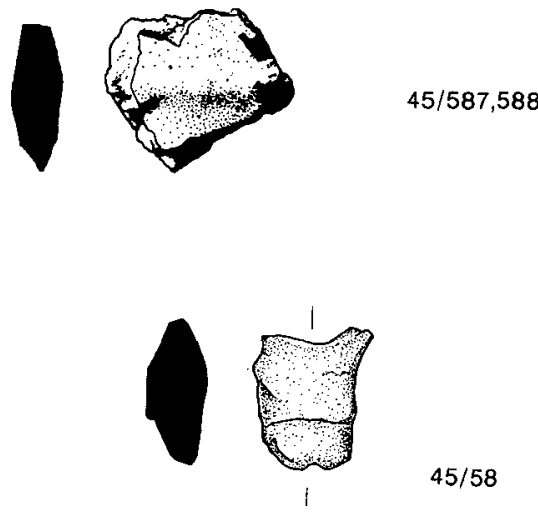

$45 / 58$

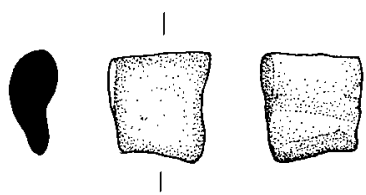

ILlus 27 Fort and Homestead 1 - selection of coarse pottery; Neolithic pottery 45/579,580,586 and 45/587, 588; LBA/IA pottery $45 / 58$ and $45 / 168$; IA pottery $60 / 26$

MEDIEVAL POTTERY (TABLE 7, FICHE 1/B12-C1)

\section{Derek Hall}

\section{Season}

This small group of pottery from Bannockburn comes largely from the topsoil and subsoil horizons. It has been sorted into identifiable fabric types and they are described and discussed separately. The fabrics have been identified by eye and no petrological examination has been carried out.

East coast white gritty ware Seven small bodysherds in this fabric type are present. Current work has identified three regional production centres in the Borders, Fife and Lothian (Haggarty 1984; Hall forthcoming, Brooks 1980). Unfortunately the Bannockburn sherds are too small to warrant positive identification of vessel form and type. However, all seven sherds would seem to be from cooking pots and of a 14th-century date.

Local? ware This fabric is oxidized red with a light grey core. It contains angular quartz grits and small black rock inclusions. The sherds have a white slip on their internal and external surfaces and external smoke 


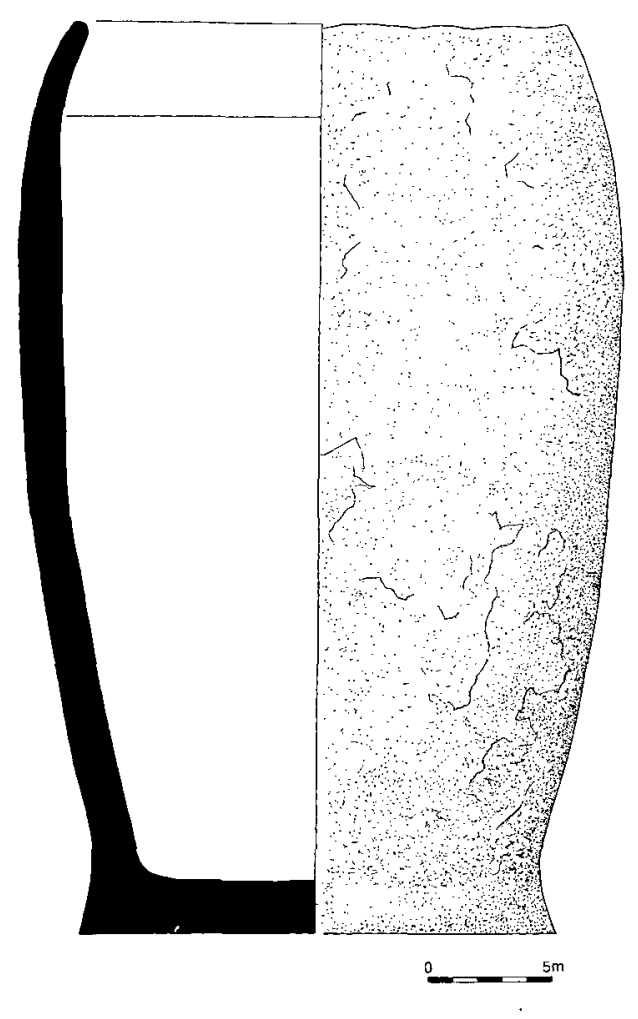

ILlus 28 Fort and Homestead 1 - Iron Age pot 94/ 126,155

blackening. They are from cooking pots and are assumed to be a local product as they cannot be identified with known fabric types.

Red sandy ware There are 24 sherds in this oxidized sandy fabric. Two are glazed dark green on their external surfaces. They are similar to fabrics from Perth and Aberdeen that have been described as local products (MacAskill 1987; Murray 1982). These sherds may originate from one of these production centres or may be a local product.

Reduced greyware There are 17 sherds in this reduced grey fabric. This fabric type has long been identified as a 16th-century Scottish tradition (Haggarty 1980). The proximity of the site at Bannockburn to an identified kiln site at Throsk (Caldwell \& Dean 1981) may suggest the origin of these sherds.

\section{Season}

East coast white gritty ware There are six bodysherds in this fabric type. They are too small to warrant positive identification of vessel form. However, they may all be from cooking pots and of a 14th century date (see 1982 season).

Orange sandy ware (local?) There are 20 sherds in this fabric type. It is fairly thin and some sherds have an internal white slip. It is similar to a putative local product from the 1982 season. These sherds are fairly small 
and make identification of vessel form difficult. This fabric does not conform to any known to the author and may be a local product of 14 th/15th century date.

Reduced light grey ware (local?) There are five joining sherds from the base and sidewall of a jug. This fabric is reduced light grey with an external light red-brown surface. Its external surface is smoke blackened and has splashes of green-brown glaze. These joining pieces are from a jug with a slightly sagged base and slight basal thumbing. It is similar to local wares from Perth and Aberdeen but may also be a local product.

Reduced grey ware There are eight sherds that belong to the 16th-century Scottish reduced greyware tradition.

\section{Homestead 1}

Oxidized orange fabric There are 23 sherds in this fabric type. It has a reduced grey core and oxidized orange internal and external surfaces. Some of the sherds retain traces of a light yellow-green glaze. These sherds appear to be from water jugs and may represent oxidized variants of the Scottish 16th Century reduced greyware tradition.

Reduced greyware There are eleven sherds in this fabric type. Four bodysherds and two joining handle fragments may be from a chamber pot. These pieces are glazed light green internally and externally and suggest a 16 th- or 17 th-century date. The remaining sherds may be from water jugs of a similar date.

\section{Conclusions}

The small group of medieval pottery from the four Bannockburn sites includes fabric types identifiable with those known from other medieval excavations in Scotland. However it is interesting that the fort produced fabric types that may represent local products of the Bannockburn/Stirling area. This is particularly interesting as they seem to suggest a 14th/15th-century date, while the nearby kiln site of Throsk is known for 17th-century production (D Caldwell, pers comm) though, so far, no earlier production has been identified. As the bulk of the pottery comes from topsoil horizons it may be regarded as not particularly significant but would form a useful group for comparison with any further excavation in the area.

\section{THE GLASS BEAD}

\section{Julian Henderson}

The glass bead (45/160, illus 29) from Bannockburn was recovered from topsoil on the 'nose' of the promontory. It is a type which commonly occurs in Early Christian Ireland and Scotland. The matrix of the bead, composed of opaque pale blue glass, is a cylindrical core around which three observable strips of glass cable have been wound to produce a subglobular gross shape. Each length of cable is composed of a helix of transparent pale blue and opaque white glass. The central hole tapers from

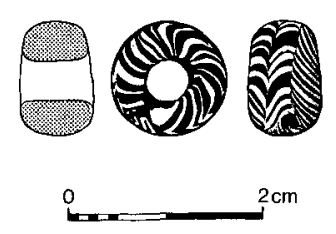

ILLUS 29 Fort and Homestead 1 - glass bead 45/160 
$4.4 \mathrm{~mm}$ to $4.1 \mathrm{~mm}$. This suggests that the implement (possibly a metal rod) on which the core of the bead was originally manufactured also tapered.

Dimensions $(\max ):$ Diam $=11.5 \mathrm{~mm}$; Depth $=7.9 \mathrm{~mm}(\min 6.8 \mathrm{~mm}) ;$ Diameter hole $=4.4 \mathrm{~mm}(\mathrm{~min}$. $4.1 \mathrm{~mm})$.

\section{Chemical composition (see Table 8 , fiche $1 / C 2$ )}

The very pale opaque blue glass forming the core (analysis 1 ) is a soda-lime-silica glass coloured by a combination of copper and iron oxides (with a possible, non-detectable, level of cobalt). The opacity may be due to an antimonate compound, perhaps calcium antimonate, though the presence of many bubbles in the glass is a more likely explanation. The presence of manganese oxide is to be expected in soda-lime-silica glass produced in the sub-Roman tradition and may have been associated with the copper when originally added to the glass batch. The transparent pale blue glass which forms part of the decorative cable (analysis 2) is also of a sodalime-silica composition with comparable levels of most elements to that found in analysis 1 for the opaque blue glass. It is evident that a similar stock of glass was used for both. The other part of the cable, an opaque white glass, also contains very similar levels of major components to the other two glasses (compare analysis $1,2 \&$ $3)$. It is apparent that very similar, if not the same, stock of glass was used to manufacture all three. The opaque white colour is produced by tin oxide, the tin replacing some of the sodium-oxide in the glass. Tin oxide is regularly found in opaque glasses of the first millennium AD.

THE METAL ARTEFACTS (TABLE 10, FICHE 1/C4-C5)

\section{Jenny Shiels}

The ironwork from the two sites consists of seven objects, four of which are nails. It is likely that the small size of this assemblage is partly due to local soil conditions, which were unfavourable to the survival of metal objects. With the exception of one $(60 / 1)$ which has been formed into a hook, no typological class can be assigned to the nails due to their poor condition. An iron knife with a whittle tang (60/22) may be medieval in date and such knives are known from Perth (Holdsworth 1987,131 ) where they date to the 12 th to 14 th century AD.

\section{THE CHIPPED STONE (TABLE 11, FICHE 1/C6-C10)}

\section{Bill Finlayson}

1982 season The chipped stone pieces recovered from the 1982 season represent a very heterogeneous collection of material. There are small flakes of very good flint (and other materials, pitchstone and chalcedony), and large flakes of crude materials, including coarse-grained quartz and siltstone. The former presumably are imported, in the case of the pitchstone over a considerable distance, the latter presumably are local. This dichotomy is emphasized by the technologies used, a standard flaking technique on the larger coarser materials, and probably a soft hammer bladelet technique on the fine materials. There is, however, other than the small pieces found, very little evidence for this microblade technology. There are no cores and no complete blades. The presence of one piece with 'microlithic' retouch and one atypical microburin suggests that these pieces may be the remains of a residual Mesolithic chipped stone scatter. The pitchstone fragment could, of course, belong to later prehistory, as pitchstone was transported in bladelet, or bladelet core form, from the Mesolithic to the Bronze Age (cf Ritchie 1968). It is impossible to say whether the rest of the assemblage is related 
to this material, and simply represents the technological response to 'cheap' local material, or belongs to a different phase of activity.

1985 season The collection of chipped stone pieces from excavations in 1985 consists of a small quantity of debitage, very varied in the raw material used. Of the 14 pieces, four are flint, three agate, three quartz, one quartzite and two possibly flint. Damage to the surface caused by burning is common, causing some problems with material identification. There is also a flake of coarse stone (94/53), probably produced by the heat shattering of a cobble. Of the pieces with secondary modification, one possibly retouched piece (94/130) has been so badly burnt that it is impossible to be sure that the putative retouch is not simply damage from burning. The only other retouched pieces are two small quartz flakes (94/105a and b), where the retouch is very hard to see with the naked eye. None of the pieces belongs in any typological category and little can be said of such a small sample of debitage.

Homestead 1 (1984 season) Two pieces of chipped stone were recovered from this site. Both are small pieces of debitage with no secondary working.

THE COARSE STONE ARTEFACTS (TABLE 12, FICHE 1/C11-C13)

Ann Clarke

Eighteen objects of coarse stone were recovered from the excavation. The cobbles are mainly of sandstone and there is one of dolerite. Two of these (45/519 and 45/628) have no obvious sign of wear and may in fact be natural whilst another (45/136) is only lightly pecked. On one cobble (45/ 161) the face has been worn right out to the edges and is smooth and shiny. It may be considered as some form of grinder. A fragment of coarse grit (45/89) also exhibits a flat worn face although it is rougher in texture than the previous piece. Evidence for grinding is also seen on the smoothly worn faces of two small fragments of tabular sandstone (45/188 \& 45/91). There is one hone which has been formed on a sandstone cobble (45/90) and there are three perforated objects which include a spindle whorl (45/2, illus 30$)$ and the surviving face of a shale ring (45/585, illus 30$)$.

Larger pieces include two saddle querns, one of which is of sandstone and is quite small with a dished face (45/414). The other is more slab-like in form (45/412) and is of coarse grit with a shallow concave face which has been worn right out to the edges. This quern is burnt and was found in a fragmented condition as post-hole packing. The other large piece is an irregular block of sandstone with a heavily pecked area on one face forming a rough hollow (unnumbered).

The battle-axe (45/67, illus 30$)$ was recovered from the topsoil. It is of quartz dolerite and has been broken across the shafthole with the butt end surviving. the butt is expanded with a flat end and conforms to Roe's type D battle-axe (Roe 1966); thus it can probably be placed within the intermediate and developed battle-axes as defined by Roe (1979). Smith (1979) has proposed a timespan of four radiocarbon centuries from the 17th to the 13th century BC for the use of such implements.

Unfortunately, 11 of the pieces were recovered from topsoil or were unstratified. Of the stratified material, the two saddle querns, particularly 45/412, are most likely to be of Iron Age date as indicated by the shallow working faces which have been worn right out to the edges (CloseBrooks 1983). The shale ring and slab grinder were recovered from a ditch and a post-hole and it is likely that both of the cobble grinders, the slab grinder and the hone are also of Iron Age date. 

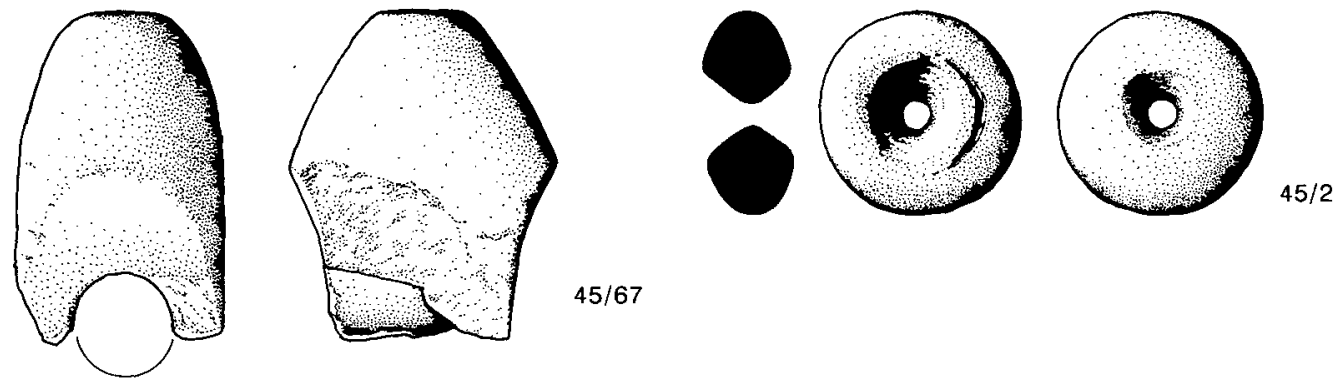

$45 / 67$
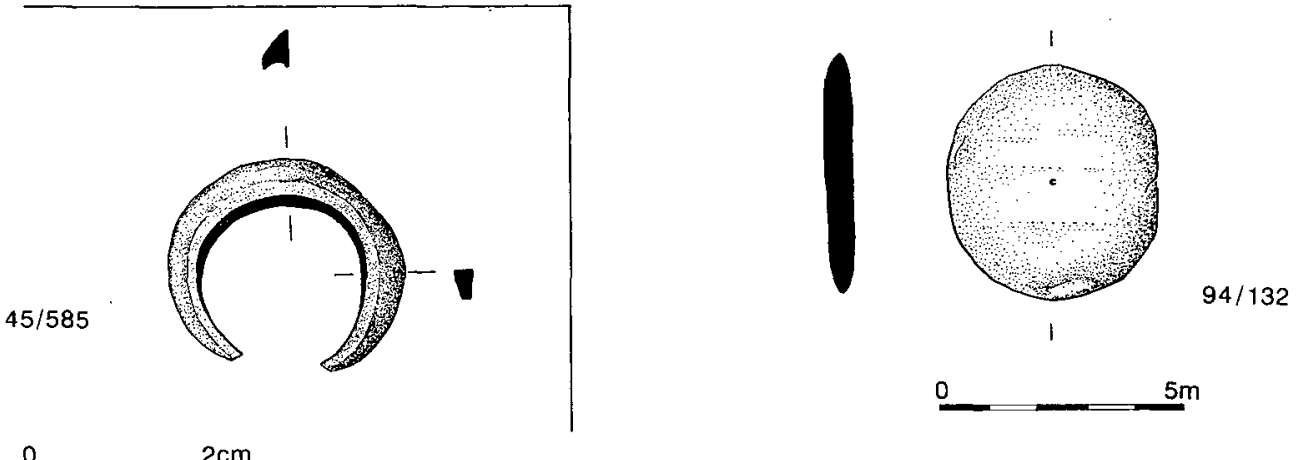

IL_Lus 30 Fort and Homestead 1 - selection of coarse stone; EBA battle-axe 45/67; spindle whorl 45/2; shale ring $45 / 585$; stone disc $94 / 132$

\section{PALAEOENVIRONMENTAL REPORTS}

POLLEN ASSESSMENT

\section{Jacky Birnie}

\section{Site context}

The geomorphological context of the bog from which the peat for pollen analysis was taken is crucial to the interpretation of the pollen record. The sampled peat had accumulated to a depth of $2.75 \mathrm{~m}$ in a shallow valley immediately adjacent to the promontory site (see Area 4, east slope). Two small valleys are cut into the abandoned cliff-face, forming the promontory between them. Only the west valley carries surface drainage, but in the past the valley on the east side of the promontory would also have been occupied by a stream. Since that time the poor drainage of the valley floor has led to peat accumulation, and any drainage is now subsurface.

The steep slopes into which this valley is cut are sea cliffs of late glacial age, formed in till with overlying raised beach deposits (BGS 1969a), and abandoned as a consequence of sea-level fall between 10,000 and 8500 BP (Sissons 1966; Brooks 1972; Kemp 1976 ). Later in the Holocene the sea level rose again, reaching the foot of the cliffs and depositing the carse clays across the entire Forth valley, until about $5500 \mathrm{BP}$. Wetter conditions may have contributed to the spread of alder on 
the slopes around the valley and to the initiation of blanket peat in upland sites (Eydt 1960). After 5500 BP the sea level fell once again, and the carse clays of the valley floor, being nearly flat, became marshland with raised bogs forming in some areas. There are remnants near the site, at Letham Moss and Dunmore Moss.

This context provides a framework of regional environmental change which contributes to understanding the phases of wetter and drier conditions apparently represented in the peat analysed here. Pollen within the peat may represent the drier habitats of the sands and gravels forming the promontory and its 'plateau' hinterland of raised beach, the steeper slopes, and also the wet habitats of the main Forth valley floor as it changed from marsh to firth, to marsh again, and then to raised bog. The extent of the catchment area likely to contribute to the pollen profile depends on the nature of the site. A loch will have a regional catchment area, a raised bog is likely to be dominated by local pollen. An incoming stream may bring pollen from an environment beyond the bog itself.

\section{Peat stratigraphy}

The trench that was cut into the bog in this valley would have indicated if this was actually a basin site, and the organic sediments, sampled by means of a sequence of 11 monolith tins, would have been identifiable as lake sediments at the base. The basal layer, in the lowest $0.5 \mathrm{~m}$ of the section, was actually a very dark, structureless and compacted organic deposit (illus 31 ). It contained wood fragments throughout. It was not a lake sediment. Accumulation at this site therefore began as a form of blanket peat, albeit at a flush site, on a poorly-drained but sloping surface. This lowest level was well-humified, perhaps as a consequence of relatively good drainage at this time compared to later. This is not surprising on a freely-draining substrate.

At $2.25 \mathrm{~m}$ below the surface the peat showed a much lower degree of humification and contained large wood pieces. Scattered sand grains were present, and these increased in frequency up to $1.75 \mathrm{~m}$. Some sand lenses were apparent at around $1.90 \mathrm{~m}$. Apparently drainage was increasingly impeded, whilst trees continued to grow at the site. The sand suggests surface water reaching the site from the drier areas above, although the lenses could be a consequence of later deposition within natural pipes of subsurface drainage in the peat.

Humification increased again at around $1.75 \mathrm{~m}$, with over a metre of peat soft and wellhumified. Sand grains were scattered throughout with particularly coarse grains at $1-1.25 \mathrm{~m}$. There was no wood apparent above $1.25 \mathrm{~m}$. Between $0.6 \mathrm{~m}$ and $0.7 \mathrm{~m}$ from the surface silt and clay was present within the organic material, indicating that surface water, carrying fine sediment, was reaching the site. Above $0.6 \mathrm{~m}$ the peat was predominantly of moss and poorly humified, suggesting no enrichment from surface water, but continued wet conditions (approximating raised bog). The uppermost $0.2 \mathrm{~m}$, with clay and stones mixed into an organic matrix, might suggest that a soil had been artificially formed on the peat base. Alternatively, a recent phase of erosion from the slopes above the site has led to an influx of minerogenic material, which has been cultivated into the peat surface.

\section{Pollen stratigraphy}

The pollen record was subject to rapid analysis, for assessment purposes only. Three samples, each $1 \mathrm{~mm}$ thick, were taken from each monolith tin $40 \mathrm{~mm}, 120 \mathrm{~mm}$ and $200 \mathrm{~mm}$ from the base of it. Each of the 33 samples was prepared by standard methods of disaggregation, sieving and acetolysis (Faegri \& Iversen, 1975). Hydrofluoric acid was also used to remove silt and clay where necessary. In addition to this, sample volumes were measured and tablets of exotic Lycopodium spores were added to facilitate pollen concentration assessment. Samples were mounted in silicone oil and counted at a magnification of $x 600$. Counting of only whole or half 
slides avoided problems of pollen sorting on the slide, but led to variable pollen counts. At each level a complete slide was counted (by means of $1 \mathrm{~mm}$ traverses) unless 300 grains had been identified at the half-slide point. The resulting diagram gives good reproducibility for the main pollen types, such as Alnus, Corylus and Poaceae; and for groupings such 'arable weeds'. It is not significant in terms of presence or absence of individual pollen types present at low levels.

\section{Results}

The pollen diagram (presented in summary form on illus 31 and in a complete form in the archive of the project records at the NMRS) showed a number of well-defined vegetation changes, which, with the radiocarbon dates obtained on the zone boundaries, give a useful environmental context for the excavated site.

Zone 1 comprised the basal well-humified peat, which was the precursor to the bog development. Pollen preservation was extremely poor in this zone, giving only about 50 identifiable grains, most of which were Betula, and corroded Filicales spores.

Zone 2, from $2.2 \mathrm{~m}$ to $1.3 \mathrm{~m}$, was characterized by high Alnus values (between $50 \%$ and $60 \%$ ) and improved pollen preservation. Corylus and Quercus had a sustained pollen record of about $12 \%$ and $8 \%$ respectively. Filicales continued to be well-represented, with a peak of $38 \%$ mid-zone. Total pollen concentration increased through the zone. Continuous presence of Rumex and Poaceae pollen, and occasional Caryophyllaceae and cereal grains, suggest some agricultural disturbance in the area. Higher pollen counts in this zone might well have led to a more sustained representation of other cultivation indicators, but the dominance of tree pollen suggests fairly extensive woodland.

Zone 3, from $1.3 \mathrm{~m}$ to $1 \mathrm{~m}$, was marked by a pollen concentration peak. Such a peak may be associated with inwash of redeposited pollen grains. Alnus pollen reached its highest levels here, exceeding $70 \%$ of the total, but wood fragments were no longer present in the peat. Continuous records of cereal-type pollen grains and Plantago began at the onset of this zone. Lactuaceae and Chenopodiaceae appeared, increasing the spectrum of disturbance-indicators. Small quantities of Rubiaceae, Polygonum and Vicia-type add to the impression of diversity, although the value of each of these individually is not significant at this level of counting. Filicales spores were much reduced. Ulmus, which had a continuous presence below this point, despite the low pollen sum, disappeared from the record at the top of this zone.

Zone 4, from $1 \mathrm{~m}$ to $0.65 \mathrm{~m}$, showed a dramatic fall in total pollen concentration. Alnus was reduced to a steady level of $30 \%$ and Quercus fell to only $2 \%$. Poaceae increased to around $40 \%$ of the total. Cyperaceae became significant for the first time, at around 5\%, and there was a low, but sustained, presence of Ericales. The variety of herbaceous types continued to increase.

Zone 5, from $0.65 \mathrm{~m}$ to $0.45 \mathrm{~m}$, is where Alnus pollen fell to low levels for the first time. Poaceae continued to rise, and cereal-sized grains reached over $10 \%$ of the total count. This coincided with a layer of poorly humified spongy peat with no sand or silt content, and extremely low levels of pollen concentration, which suggests rapid accumulation of true (raised?) bog peat.

Zone 6 pollen concentrations rose again. Both Lactuaceae and Asteraceae (Compositae) pollen types were particularly well represented, in a Poaceae-dominated record, with continued presence of a wide range of agricultural indicators. 


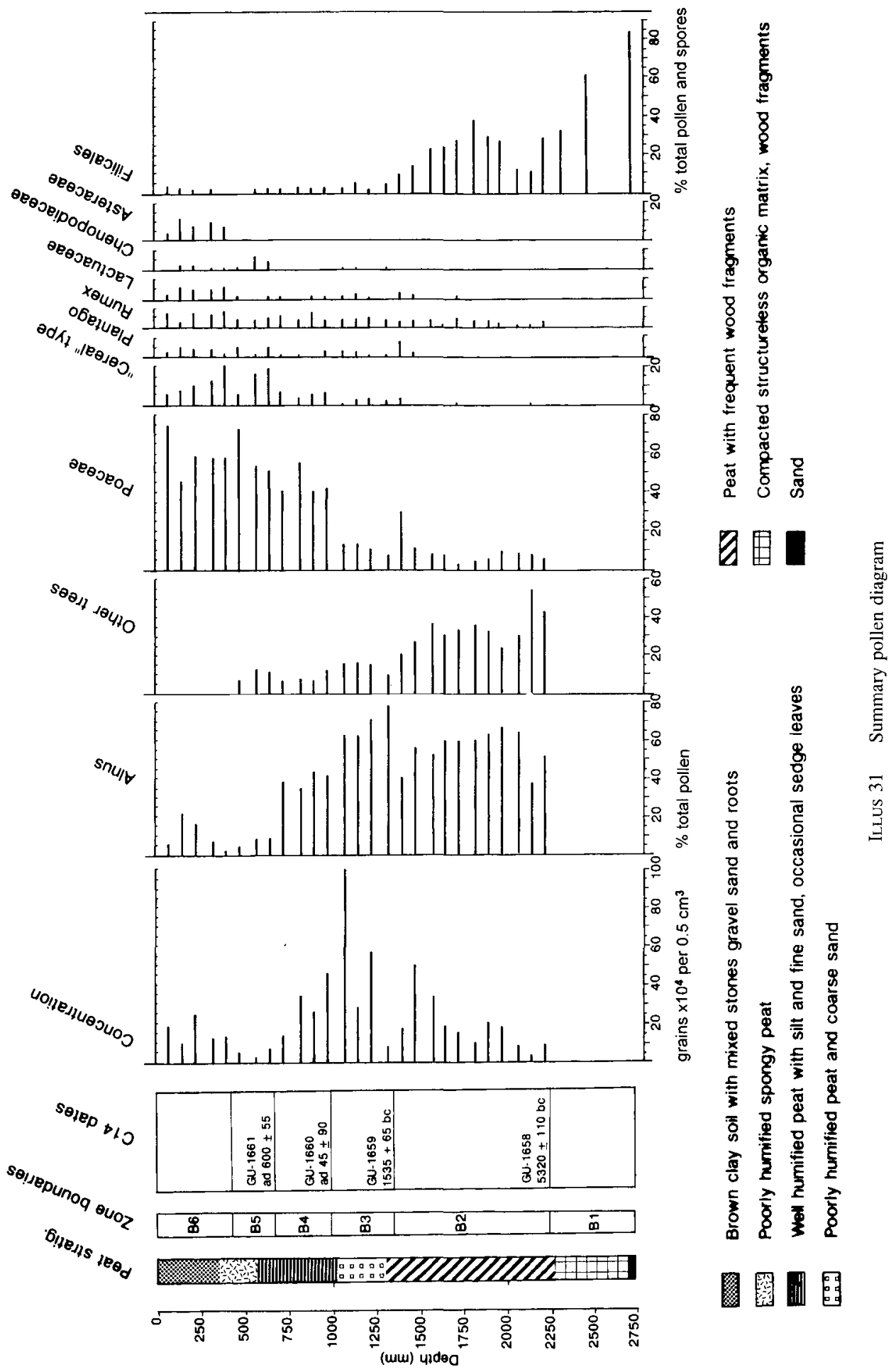


TABLE 1

Summary of peat column radiocarbon dates

$\begin{array}{lllll}\begin{array}{l}\text { Depth from } \\ \text { bog surface }\end{array} & \begin{array}{l}\text { Zone } \\ \text { (start) }\end{array} & \text { Interpretation } & \text { Date (uncal) } \\ 2.20-2.22 \mathrm{~m} & \mathrm{~B} 2 & \text { Base of pollen profile } & 7270 \pm 110 \mathrm{BP} & \text { Gab no } \\ 1.37-1.39 \mathrm{~m} & \mathrm{~B} 3 & \text { Initial limited clearance at side } & 3485 \pm 65 \mathrm{BP} & \mathrm{GU}-1658 \\ 0.97-0.99 \mathrm{~m} & \mathrm{~B} 4 & \text { Beginning of continuous clearance? } & 1905 \pm 90 \mathrm{BP} & \mathrm{GU}-1660 \\ 0.62-0.64 \mathrm{~m} & \text { B5 } & \text { Cultivation maximum? } & 1350 \pm 55 \mathrm{BP} & \mathrm{GU}-1661\end{array}$

\section{Radiocarbon dates of the main changes}

Two-centimetre slices of peat from the monolith, at the Zone $1 / 2$ boundary, the Zone $2 / 3$ boundary, the Zone $3 / 4$ boundary and the Zone $4 / 5$ boundary, were trimmed and submitted to the Scottish Universities Research Reactor Centre for radiocarbon assay. The results are given in Table 1.

\section{Interpretation}

The initiation of peat formation in the valley requires either a climate change or a rise in base level. Both would have been a consequence of the transgression of the sea into the main Forth valley which culminated at about $5500 \mathrm{BP}$.

In the light of other palaeoenvironmental work in the region, the Zone $1 / 2$ date of around 7500 BP is a little surprising. As outlined above, the widespread development of alder woodland around the slopes of the Forth valley could certainly have occurred at any time between about 8000 and $5500 \mathrm{BP}$, but a quite distinct regional elm decline is found in pollen diagrams from the Teith valley (Lowe 1982), on the Campsie Fells (Eydt 1960) and in Flanders Moss (Turner 1972). This regional elm decline, as elsewhere, is usually dated to around $5000 \mathrm{BP}$, but is not apparent from the Bannockburn pollen profile. The disappearance of the elm, at the Zone $3 / 4$ boundary, is dated to around 1900 BP. In scale this change is similar to that at nearby Letham Moss (Durno 1976) which, having formed on the carse clay, must post-date $5000 \mathrm{BP}$. Hence, on the basis of the preliminary pollen evidence, there is reason to doubt whether Zone 2 predates $5000 \mathrm{BP}$. As the solid geology of the area comprises the Limestone Coal Group of millstone grit (BGS 1969b) there is some reason to be suspicious of radiocarbon dates near the base of profiles where carbonaceous material of infinite age could be present. However, this is not a lake sediment, in which hard-water error could be a factor. As the soils on the site appear to be base-poor it may be argued that there is little evidence for contamination in this instance. For a more recent general view of the elm decline in Scotland, see Richard Tipping's review article in vol 124 of the Proceedings (1994).

Whatever the basal date, prior to around 1990 to $1750 \mathrm{BC}$ this small valley was occupied by an alder woodland with a fern-rich understorey. Whilst peat was accumulating it is likely that nutrient-bearing water flushed the site at intervals, favouring the continued growth of alder rather than a succession to alder/birch woodland or acid bog. This water may have carried sand into the valley from the promontory slopes and the small catchment area comprising about $1 \mathrm{sq} \mathrm{km}$ of the cliff-top plateau drained by the contemporary stream. The sporadic indicators of cultivation may come from the same source. At this time the main valley floor of the Forth would be evolving from salt to freshwater marsh, and then to extensive wet woodland of oak and alder. It is likely to have contributed much tree pollen to the site, and may be the source of oak and birch pollen, as well as alder. Elm, lime and hazel would have needed better drainage, and their presence suggests woodland on well-drained slopes if not on the plateau surface. 
Up until the Zone 3 boundary the site became gradually drier, with peat humification and pollen concentration both increasing; but just after around 1900 to $1750 \mathrm{BC}$ there was a marked change with a major influx of sand, possibly with reworked pollen, and the beginning of continuous cereal cultivation in the vicinity. The site itself was wetter, and the most likely area for cultivation would be the well-drained soils on the plateau top or more gentle slopes adjacent to the promontory. The fact that reworked pollen seems to have been alder rather than anything new suggests it has come from close to the site, perhaps from humic soils on the surrounding slopes.

According to the radiocarbon dates, Zone 3, comprising less than $0.4 \mathrm{~m}$ of peat, represents some 1900 years of peat accumulation. Yet the peat is poorly humified, suggesting rapid accumulation. There is, therefore, a possibility that some erosion has taken place here, in addition to the inwash, leading to a loss of record.

During the first two centuries $\mathrm{AD}$ the on-site vegetation was changed to a wet grassland, with sedges and some heath. Presumably the remaining wood was cut or burnt. There may have been some remaining alders, but it is equally likely that the alder pollen comes from the woodland of the Forth valley floor. Elm has disappeared from woodland in the vicinity. Fine minerogenic sediments continue to be washed into the site, but there is less of an influx of sand. Whilst evidence of cultivation in the vicinity is continuous the sedimentary record, at least, is less erratic. This may indicate a more stable situation than in the previous zone.

The date around $\mathrm{AD} 650-700$ marks the beginning of the zone in which cultivation indicators are at a maximum and woodland cover at a minimum. As all tree pollen types in this zone are at low levels it seems likely that the wet woodland on the main Forth valley floor had been cleared, and that evidence of agriculture derives from this area also. The lack of minerogenic input to the pollen site also suggests that arable activities on the slopes and plateau above the site were less, rather than more, intensive at this time, although the amount of cereal pollen might suggest otherwise.

\section{CARBONIZED SEEDS (TABLE 13, FICHE 1/C14-D14)}

Alan Fairweather

1982 Season

Organic remains were extracted by flotation from 248 samples, and 215 samples contained identifiable material. Of the samples which contained cereal remains, only five had parts other than grains. This material was insufficient or too damaged to allow closer identification of the cereals found. The lack of cereal parts other than grains did not indicate cleaning or crop processing.

Avena spp The oat grains found varied in size and morphology. Without more parts, it was not possible to identify the grains beyond genus level. Size range is not only a factor of species but also dependent upon the position of the grain in the panicle. Allowing for these caveats it can be said that most grains fell within the range expected for Avena strigosa and Avena fatua. A few larger and plumper grains scattered throughout could have been Avena sativa. The relationships of the Avena species and their probable agricultural development are outlined by Holden (1976).

Hordeum The barley grains were nearly all hulled. The confirmation of the few unhulled grains suggested that they had been hulled but had lost their hulls by burning and abrasion. From the range and proportion of grain size and twisted grains, the barley was probably a six-rowed compact type.

Triticum A few grains were tentatively identified as wheat but none was sufficiently undamaged to give a positive identification. The incidence of these grains was very low. 


\section{Cereal remains in general}

There was very little material that could be described as chaff which would have allowed closer identification. A proportion of the cereal material was fragmented or broken. This would seem to have occurred after carbonization.

\section{Other material}

The occurrence of Empetrum nigrum pyrenes (crowberry 'seeds') in eight samples is of some interest (three from contexts related to main structural elements viz samples 45/115 from House 1 F29 entrance, 45/284 from House 1 F24 entrance and 45/350 from miscellaneous pit F36). The identification of the pyrenes was confirmed by Camilla Dickson.

Crowberry is a shrub of blanket bog or acid heath. Its black fruits are edible, if rather bland. It grows in similar conditions to the more productive and palatable blaeberry (Vaccinium myrtillus) and cowberry (Vaccinium vitis-idaea - both with $85 \%$ similarity in habitat to Empetrum according to Grime et al 1988) One would expect these latter species to be represented in a food pip assemblage. There is not a significant difference in fruiting time (JulySeptember) between these berries. Sources of Empetrum could be fortuitous as part of thatch or fuel. One would, expect however, parts of carbonized twigs to be present. Pyrenes could have been derived from animal, bird or human faeces burned with bedding, or the remains of stomach contents.

Of special interest are the remains of seaweed (marine algae) remains from four samples (three from F36, one from Antenna 2) which Professor A D Boney has confirmed and tentatively identified as Fucus and/or Pelvetia species. Camilla Dickson (pers comm) remarks that these are very similar to remains she has found in samples from Orkney. The reason for these remains being on site is uncertain. During the period of settlement, the Firth of Forth was perhaps nearer than at present, allowing saline waters to support a stand of marine algae to be thrown up on the littoral zone and collected by man. The dried material could have been used for fuel or as a fresh fertilizer or as a nutrient-rich ash. If the site were far from the littoral zone at the time it implies that the seaweed had a special value. It is bulky when fresh, with more than an $85 \%$ proportion of water. Burnt Fucoid and Laminarian species of seaweed have long been known as rich sources of potassium (potash K20) and besides its value as a fertilizer it may be used to prepare lye. This is the valuable constituent of ash dissolved in water. Lye has been used since antiquity for washing and as a mordant for fixing dye.

BONE (TABLE 14, FICHE 1/E1-E3)

\section{Lin Barnetson}

Burnt bone fragments, including three pieces of unburnt bone, were recovered as finds. Other burnt bone was recovered from the soil samples flotation process. The full list of results is given in the archive of the project records at the NMRS. Table 14 (fiche) is data extracted from the full list to show bone finds identified to species and/or bone type from the main structured elements only. Of the full list of 262 finds, 36 bone finds from the main structural elements were identified to species and/or type. These included bone fragments of cattle (16), sheep/goat (18) and pig (two). Because of the poor quality of the results of the 1982 bone assessment, and because much less bone was recovered, the material from the 1985 season was not assessed. 
TABLE 2

Summary of radiocarbon dating

Lab No.

(GU-)

Context

Sample No.

Uncal Date

396

1652

Bog

$\pm 60 \mathrm{BP}$

West Flank

Ditch F241

1654

Pit F35

House 1,

ring-groove

1656 Firepit F30

Pit F35

Pollen profile

Zone B2 start

1658

$\begin{array}{ll}1659 & \text { Pollen profile } \\ 1660 & \text { Zone B start } \\ \text { Pollen profile }\end{array}$

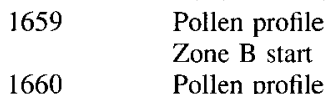

$\begin{array}{ll}1660 & \text { Pollen profile } \\ \text { Zone B4 start }\end{array}$

1661 Pollen profile

Zone B5 start

F35 Average

386

347

187

300

345

Peat sample 1

Peat sample 2

Peat sample 3

Peat sample 4

Too small

$940 \pm 60 \mathrm{BP}$

$2445 \pm 60$ BP

$2255 \pm 60 \mathrm{BP}$

$975 \pm 60 \mathrm{BP}$

$7270 \pm 11 \mathrm{BP}$

$3485 \pm 65 \mathrm{BP}$

$1905 \pm 90$ ВР

$1350 \pm 55 \mathrm{BP}$

$957.5 \pm 42.5 \mathrm{BP}$

\begin{tabular}{ll}
\multicolumn{1}{c}{$\ldots$ Date Range $\ldots$} \\
1 sigma & 2 sigma \\
$1258-1020$ BC & $1370-932$ BC \\
& \\
AD $1018-1166$ & AD $980-1230$ \\
$766-406$ BC & $790-400$ BC \\
$395-209$ BC & $400-180$ BC \\
AD $1003-1155$ & AD $960-1200$ \\
$6213-5992$ BC & $6390-5886$ BC \\
1896-1739 BC & $2016-1670$ BC \\
AD 3-218 & 110 BC-AD 331 \\
AD 644-684 & AD $600-780$ \\
AD $1018-1155$ & AD $955-1169$
\end{tabular}

\section{RADIOCARBON DATING}

\section{James S Rideout}

At the end of the 1982 season, two samples of waterlogged wood from the bog, and nine samples of carbonized wood from various contexts, were identified (see the full wood and charcoal report in fiche (1/E4-E7) and Table 3, below). The two waterlogged wood samples, four of the charcoal samples (marked by asterisks in the full report), and four samples from the peat profile, were submitted to the Scottish Universities Research Reactor Centre for radiocarbon dating. The dates have been calibrated according to the program given by Pearson \& Stuiver (1986) in Radiocarbon. One sample of waterlogged wood (GU-1653) proved too small for radiocarbon assay after pre-treatment. The remaining results are set out in Table 2, and individually discussed, below.

TABLE 3

Wood Identifications of radiocarbon dating samples ( $\mathrm{R}$ McCullagh)

\begin{tabular}{|c|c|c|c|c|}
\hline $\begin{array}{l}\text { Site Sample } \\
\text { no. }\end{array}$ & $\begin{array}{l}\text { Lab. no. } \\
\text { (GU-) }\end{array}$ & Context & Species & $\begin{array}{l}\text { Total } \\
\text { weight }\end{array}$ \\
\hline 396 & 1652 & Bog timber & Quercus sp. & - \\
\hline 386 & 1653 & west flank ditch F24l & Betula sp. bark & - \\
\hline 347 & 1654 & Pit F35 & $\begin{array}{l}\text { Alnus glutinosa } \\
\text { Corylus avellana }\end{array}$ & $17.8 \mathrm{~g}$ \\
\hline 187 & 1655 & $\begin{array}{l}\text { House } 1 \text { ring- } \\
\text { groove }\end{array}$ & Quercus sp. & $18.1 \mathrm{~g}$ \\
\hline 300 & 1656 & Fire pit F30 & $\begin{array}{l}\text { Corylus avellana } \\
\text { Quercus sp. }\end{array}$ & $31.9 \mathrm{~g}$ \\
\hline 345 & 1657 & Pit F 35 & Corylus avellana & $15.2 \mathrm{~g}$ \\
\hline
\end{tabular}




\section{HOUSE 1 RING-GROOVE (GU-1655) $2445 \pm 60 \mathrm{BP}$}

The sample was taken from a post-pipe (one of two) in the door terminal of the ring-groove. As noted in other parts of this report, this type of context is not very secure since material from it could be relict material, material from the occupation of the house, or material from activity later than the house, falling into the void left by a rotting timber, or deliberately removed timber. Carbonized wood from post-pipes could, however, be the result of in situ burning of the post. This last is unlikely here since the wood was identified as small diameter oak roundwood (at least $0.05 \mathrm{~m}$ in diam). In the absence of more securely contexted material from the house, however, this is accepted as providing a broad date for the occupation of House 1, and therefore, Homestead 2 (although see calibrated date range above).

\section{FIRE PIT F30 (GU-1656) $2255 \pm 60 \mathrm{BP}$}

The sample was taken from the main fill of the pit, consisting of burnt and charcoal-stained soil. The sample securely dates the pit since the burning was in situ. The pit cut the porch slot F23 and, therefore, gives a terminus ante quem for the porch of House 1. Apart from the direct stratigraphic relationship, F30 could not be definitely associated with the main structural elements. It is assumed, however, that it belongs to some point in the occupation of the defensive periods of the site.

\section{LARGE MISCELLANEOUS PIT F36 (GU-1654) 940 60 BP AND (GU-1657) $975 \pm 60$ BP}

Both samples were from patches of charcoal near the bottom of the pit. Each sample was one of four patches. The samples are secure. The pit was $1.67 \mathrm{~m}$ long, $1.24 \mathrm{~m}$ wide and $1.01 \mathrm{~m}$ deep. Its function is uncertain. In the four 'corners' of the pit were near-vertical grooves in the pit sides, suggestive of timber upright impressions (of timbers $0.05-0.1 \mathrm{~m}$ diam). It is also interesting to note that the three macroplant samples from the pit contained fucoid algae (like the bladder-wrack or fucus genus of seaweed) as the bulk of the carbonized material.

The pit was dated in the belief that it represented some activity pertaining to the occupation of the homestead or fort periods. The two statistically indistinguishable dates show the pit to be medieval. Since there was no direct stratigraphic relationship between F36 and the main structural elements, it was not possible to determine if other contexts belong to this same, late date.

\section{WATERLOGGED TIMBER FROM MACHINE TRENCH (GU-1652) $2920 \pm 60$ BP}

The worked timber was from the outer portion of a large diameter oak bole. It was located in the machine trench dug into the defences on the east flank where they merge with the bog. The timber was upright and apparently derived from in the bottom of the fill of a late (or the last) ditch cut or scarp cut . Although the location context would appear to be secure, the origin of the timber is not. Large timbers can be useful for very long periods and, even if its deposition was after use in the fort, the worked piece could have had an origin in a much earlier period. It is also possible that it was already a waterlogged timber in the bog and later disturbed during defence digging activity (like the Neolithic pottery from another east flank ditch). What the timber does suggest, however, is later Bronze Age activity in the area (although the working of the wood could have been done long after the death of the tree). A more detailed description is given in fiche (1/E4-E7). 


\section{GENERAL INTERPRETATION: FORT}

\section{DATING}

Very few contexts produced enough material for radiocarbon dating. The following is a summary of the dates, or probable dates, of the main structural elements in the same order as in the Description/ Interpretation section.

Ditch 0 produced a number of finds, two types of which help to provide a general date. The coarse pottery and shale ring from mid- to upper layers of the ditch fill are of general Iron Age date. No artefacts which could provide tighter dating were recovered, nor were finds of obviously later date. The ditch, therefore, was almost certainly excavated and mostly infilled during the Iron Age.

Ditch 8 produced no dating material. It does, however, pre-date Ditch 1 which, in turn, predates Ditch 0. All finds from Ditch 1 were from the highest ditch fills. That Ditch 1 is cut by Ditch 0 indicates that it is of Iron Age or earlier date. The single sherd of medieval pottery from high in the stratigraphy may suggest that the ditch was still visible in the Middle Ages.

Ditch 6 produced no dating material. It is, however, cut by Ditch 2. Coarse pottery of general Iron Age date was recovered from throughout the fills of Ditch 2 and one large piece of bucket-shaped cooking vessel was found broken in situ in burnt and charcoal stained soil in the middle of the stratigraphy suggesting that there was activity in the partially infilled ditch. The ditch is, therefore, probably of Iron Age date. The single sherd of medieval pottery from the B-horizon over the ditch suggests that the ditch was fully infilled by the time it was deposited.

No diagnostic finds were recovered from the fills of Ditch 3. As with Ditch 2, medieval pottery was recovered only from the B-horizon over the ditch fills. No dating material was recovered from Ditch 4 nor from Ditch 7. In Ditch 5, the final recut produced Iron Age coarse pottery from throughout the fills. Since this was the only diagnostic find type, the ditch can be broadly dated only to the Iron Age. It is worth noting, however, that a sherd of pottery from high in the fills of Ditch 2 came from the same vessel as several sherds from high in Ditch 5 suggesting that both ditches may have been recut at the same time. The B-horizon and field furrows over Ditch 5 produced medieval pottery.

In the palisades, coarse pottery of Iron Age date was recovered from only Palisade 1/2. Palisades 5 and 8 each produced a single sherd of medieval pottery. No other diagnostic finds or other dating material was recovered.

The dating of small features such as palisades or post-holes using finds or even radiocarbon dates can have its dangers. Artefacts and carbonized material in the soil backfilled around posts in such features could belong either to the same period of activity or earlier, being relict material in the soil. Artefacts of small size in backfilled soil (and in post-pipe soil) could be deposited as a result of animal activity moving them from original contexts. Artefacts and carbonized material from the soil filling the space where the posts once stood could be relict, from the active phase, or from after the active period. This problem is demonstrated by the single sherd of medieval pottery from Palisade 5 , which is earlier stratigraphically than Ditch 6 which, in turn, is earlier stratigraphically than Ditch 2 which is dated to the Iron Age.

Of the antenna slots, only Antenna 4 produced finds. One find was a sherd of medieval pottery.

No dating material was recovered from Post-Alignments 1-4.

With House 1, the same problems of dating noted above apply to all the elements of houses surviving only as negative features. A post-pipe in the north terminal of the ring-groove produced a radiocarbon date of $2445 \pm 60$ BP (GU-1655). A fire-pit (secure context) cutting the porch of the house produced a radiocarbon date of $2255 \pm 60 \mathrm{BP}$ (GU-1656). In addition, coarse pottery of Iron Age date was recovered from the ring-groove. It is probably safe to assume that the house dates to the fifth or sixth centuries $\mathrm{BC}$. 
Palisade 0 produced coarse pottery of Iron Age date. It is later stratigraphically than House 1. No dating material was recovered from House 2, Houses 3 \& 4 and Fourposters.

In Area 2, a later ditch cut produced a flake of coarse pottery from its fill. The upper fill of another ditch cut produced a quantity of 14th century medieval pottery. In Area 4 several ditch cuts and recuts were identified on the lower flank. One ditch cut produced a sherd of Iron Age coarse pottery. Another ditch produced a number of sherds of two vessels of probable Neolithic date. The Neolithic sherds may derive from activity of that period on the promontory, the remains of which were disturbed during the construction of the defences. Areas 5 and 7 produced no dating material, while in Area 6, the only diagnostic material was a flake of coarse pottery from the recut in the large pit. In Area 8, two ditches produced Iron Age coarse pottery.

\section{Other periods of activity}

Radiocarbon dates were recovered from two other contexts in the excavated area. The large pit (F36) in the internal area gave dates of (GU-1657) $975 \pm 60 \mathrm{BP}(\mathrm{GU}-1654)$ and $940 \pm 60 \mathrm{BP}$. A large worked oak timber from the bog to the east gave a date of (GU-1652) $2920 \pm 60 \mathrm{BP}$.

Two further diagnostic artefacts were recovered from the site, both, unfortunately, from the topsoil in Area 1. One was part (approximately onehalf) of an Early Bronze Age battle-axe (illus 30). The other was a glass bead probably dating to the seventh century AD. The chipped stone from the nose of the promontory (1982 season, SF numbers prefixed 45/) appears to be residual Mesolithic material, probably also from disturbed use or occupation of the site.

\section{Summary}

The dating from the fort is somewhat unsatisfactory since there was not enough material to allow a fine tuning of the dating of the main structural elements. The dating evidence from the excavated area suggests the following sequence:

1 Pre-House 1 activity, as shown by the Mesolithic chipped stone, the Neolithic pottery, the Bronze Age battle-axe and the dated timber from the bog

2 Iron Age activity, starting with House 1 at least, in the fifth/sixth centuries $\mathrm{BC}$ and probably including most, if not all, of the main structural elements

3 Post-defensive activity, as shown by the glass bead, the dated pit F36, the medieval pottery over much of the site, and the rig and furrow in the south end of Areas 9 and 10.

\section{MAIN STRUCTURAL ELEMENTS}

The unstable nature of the subsoil has affected the survival of the defences in different ways. On the promontory summit, the subsoil surface was a concreted, coarse sand which, although eroded by ploughing, was considerably less affected than other areas. Heavy erosion had severely truncated features on the upper flanks on the east side of the promontory (with the exception of Areas 2 and 3 , the west and north flanks were not investigated). The lower east flanks had suffered repeated erosion during the active defensive period interspersed with periods of accumulation of deposits from erosion upslope. Post-occupation agricultural activity has resulted in a heavy overburden of humic colluvium. As a result of this variable erosion, the defences on the summit were clearly defined while on the lower flanks, to the east of the main entrance route, the remains were confused. They could not, therefore, be related to the sequence on the summit. 


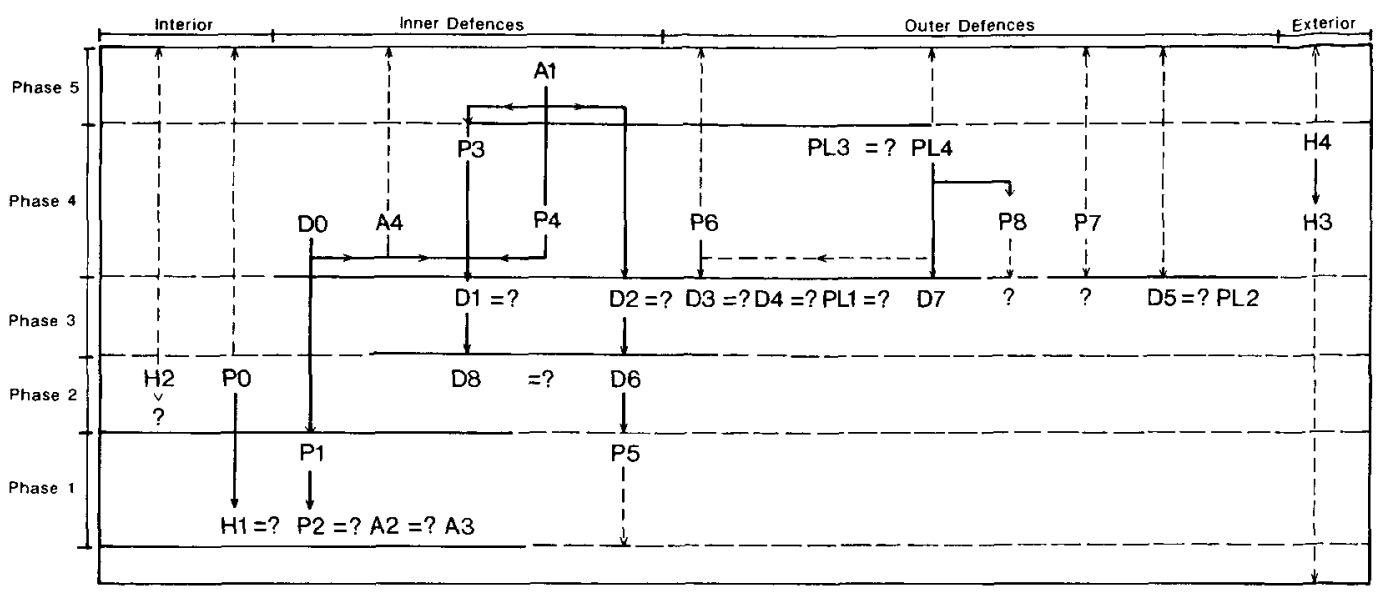

ILlus 32 Fort - interpretative diagram

On the summit, many of the defensive features could not be stratigraphically related because of truncation and the spatial depth of defences. The defences fell into two rough groupings: the inner defences, where greater activity has led to a complex sequence of relationships; and the outer defences, where few stratigraphic relationships were noted. As a result of the unstable soils, there has been too much activity on the lower flanks to allow an insight into the development of the defensive phases on the site. Instead, it is more useful to look at the remains on the summit plateau. Here, however, this must be done using the limited horizontal stratigraphy and by inference. The interpretative diagram (illus 32) is an attempt to illustrate real and proposed relationships in Areas 1,9 and 10 .

The top and bottom lines represent the limits of the time span occupied by the main structural elements (earlier to bottom, later to top). Solid lines and arrows are known relationships; = ? shows suggested contemporaneity (by inference); vertical pecked lines show 'slack' in chronological relationships. The diagram is divided horizontally into four groups of main structural elements: Interior, Inner defences and Outer defences (as noted above, the defences are subdivided on the basis of the number of horizontal relationships), and Exterior. As much as possible, the left to right positions of the elements reflect their north/south positions on the ground. The intermediate horizontal lines show the divisions between the proposed phases of the site as exhibited by the main structural elements. The structural elements can be summarized thus (Table 4):

TABLE 4

Summary of the structural elements

$\begin{array}{ll}\text { Phase } & \text { Description } \\ 1 & \text { Palisaded Homestead (2) } \\ 2 & \text { Fort 1: Bivallate } \\ 3 & \text { Fort 2: Multivallate } \\ 4 & \text { Fort 3: Univallate } \\ 5 & \text { Post-defensive }\end{array}$

Structural Elements

House 1 , Palisade $1 / 2$, possibly Antenna 2 and Antenna 3 Ditch 8 and Ditch 6

Ditches 1-5,

possibly Ditch 7 and Post-alignments 1 and 2

Ditch 0,

possibly Palisade 4 and, later, Palisade 3

Antenna 1 


\section{Phase 1: Palisaded Homestead 2 (illus 33a)}

That the entrance into the house faces the entrance through Palisade 1/2 suggests that the features may be contemporaneous. The slight remains of Antenna 2 and Antenna 3, which radiate out from the west and east entrance terminals respectively of Palisade $1 / 2$, may also belong to the same phase. This phase is placed first because of the radiocarbon dates and by inference based on current accepted models (Hownam paradigm) and similarities with Homestead 1 (above).

\section{Phase 2: bivallate fort (illus 33b)}

It is assumed, that the palisaded phase was followed at some stage by a period of fortification. This has been subdivided into 3 phases (2-4). The first fort phase, Phase 2, appears to have been bivallate, the defences consisting of two parallel, wide, flat bottomed ditches (Ditch 8 \& Ditch 6). The two ditches are seen as belonging to the same phase because of morphological similarities and because both are replaced on a slightly different alignment by ditches of different form (V-sectioned and deeper). That Ditches 8 and 6 were naturally infilled to the depth of the modern subsoil level before the excavation of the U-sectioned ditches indicates a hiatus of some length in the defensive character of the site.

\section{Phase 3: multivallate fort (illus 33c)}

This phase probably represents a longer period of activity. The terminals of Ditches 1, 2, 3 and 4 form the west side of the main access to the nose of the promontory. All have steepsided, V sectional profiles. The pattern presented by the plan of the defences, however, suggests that Phase 3 was the result of a gradual development. The larger space between Ditch 2 and Ditch 3, and a similar large space between Ditch 4 (or even Ditch 7) and Ditch 5, suggests that Ditches 1 and 2 were excavated first, followed by the addition of Ditches 3 and 4 , followed by the excavation of Ditch 5 (and possibly Ditch 7), on the basis that increasing the spatial depth of defences was done by adding ditches on the outside.

A lengthy active multivallate phase is also attested by the refurbishment of the defences. This appears to have been piecemeal in most instances, involving the redigging of short lengths of ditch, possibly as a response to partial collapse. This is shown in Ditch 2 where there is at least one recut in Cutting D2/I, but no recut in Cutting D2/II. In Ditch 3, only one section (Cutting D3/I) yielded evidence of refurbishment. In the terminal of Ditch 4 , two or possibly three recuts were noted (Cutting D4/III); in Cutting D4/II, no recuts were seen; and in Cutting D4/I, one recut was recognised. Ditch 5 is more problematic. The terminal suggested by the aerial photographs and by surface indications after topsoil stripping did not exist as such. This meant that only one cutting was excavated. It showed a large $\mathrm{V}$-sectioned ditch replaced by an equally large and deeper $\mathrm{V}$-sectioned ditch. The nature and purpose of the small $\mathrm{V}$-sectioned ditch cut into the north side of the partially infilled first cut, before the second large cut, remains a mystery. It is possible, however, that the ditch did, indeed, exist at this point, with fills similar to the subsoil, and which were not identified by the excavators.

The lines of Ditch 7 and Post Alignments 1 and 2 suggest that they, too, belong to this phase. Ditch 7 runs parallel to Ditch 4 . The position of Post Alignment 1 suggests that it may have served a function similar to a rampart revetment. Post Alignment 2 may have been an entrance feature designed to continue the line of the unfinished Ditch 5 . 

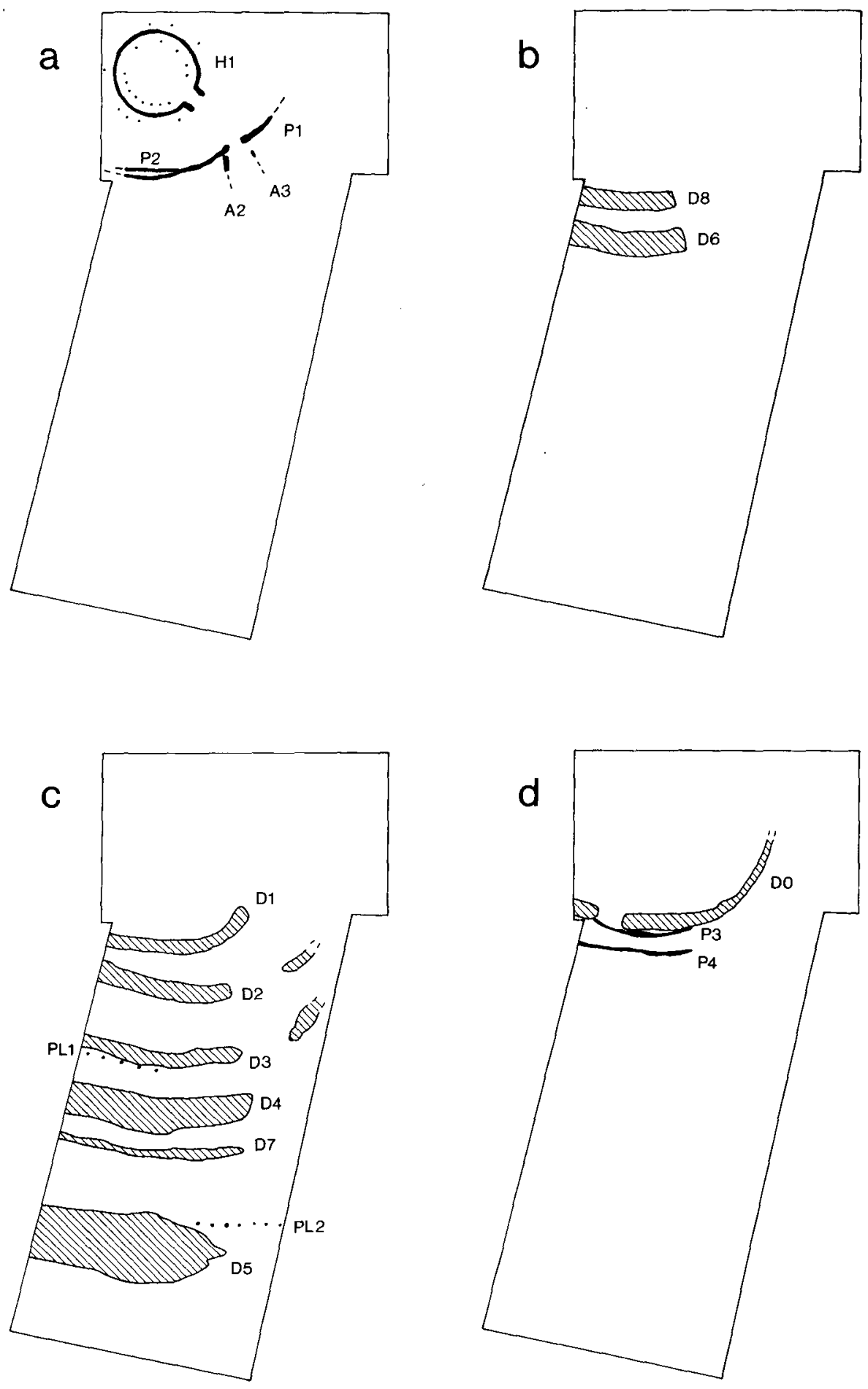

ILLus 33 Fort - simplified site plan showing proposed phases : a. Phase 1 (Homestead 2); b. Phase 2; c. Phase 3; d. Phase 4 
Phase 4: univallate fort (illus 33d)

Ditch 0 cuts Ditch 1 and, since it has a radically different entrance position from the Phase 3 defences, and has a different profile, appears to be the last defensive phase. There is no direct relationship with Palisade 4, but they follow parallel courses and both cut Ditch 1, suggesting contemporaneity. Palisade 3 , which respects the edge of Ditch 0 , was a later feature which must have blocked the entrance. It is difficult to imagine what function Palisade 3 could have served, given that it blocks the entrance through a ditch which must have been at least partially open, and at the same time runs along its outer edge to block the old main entrance route.

\section{Phase 5: antenna 1}

Antenna 1 is the latest identifiable structural element in the inner defences area. It cut across all the inner defences except Ditch 0, the edge of which it respected. Ditch 0 was, therefore, presumably still open when Antenna 1 was constructed.

\section{Unphased elements}

Of the main structural elements, 10 are not phased. They are Palisades 0, 5, 6, 7 and 8, Post Alignment 3/4, Antenna 4, and Houses 2, 3 and 4.

Palisade 5 predates Ditch 6 and, therefore, belongs to Phase 1 or earlier. The nature of the feature is uncertain. It is possibly an unfinished palisade. When one sees a palisade trench, or house groove such as in House 1, the assumption is that it was constructed by digging the trench, or long stretches of trench, first, with the spoil being dumped along the edge. The posts would then be inserted and packed in a single operation. However, a more sensible method might be to firstly cut a shallow marker trench and then dig the trench and insert the posts in a single, moving operation. After an initial cut to the final depth over a short stretch, a number of posts could be inserted and backfilled with material derived from the digging of the next short stretch. The spoil from the cutting of the marker trench would not be returned; its place would be taken by the posts. This method would cut out one shift of spoil (from the initial dump back into the trench).

Palisade 6 was seen to run over the infilled terminal of Ditch 3 and, therefore, belongs to the end of Phase 3 or later. Its line, however, being parallel to the ditch and more or less respecting the line of the main entrance as it turns northwards, indicates that the Phase 3 defences were still visible. Palisade 8 , following a parallel course $\mathrm{c} 18 \mathrm{~m}$ to the south, may be related to Palisade 6 , at least in function. The remains of Palisade 7, having no stratigraphic relationships and being too fragmentary to compare to other elements could belong to any phase. Its east/west course, however, suggests that it served a similar function to the other palisades and ditches on the plateau.

Post Alignment 3/4 was definitely later than Ditch 7 and Palisade 8, and was possibly later than Ditch 3. The post alignment, therefore, belongs to Phase 4 or later. Its course is radically different to the other main structural elements, although its course suggests that it may be associated with the entrance in Ditch 0. Antenna 4 cut the terminal of Ditch 1. Although fragmentary, its course respected the line of the main entrance and it is possible that it belongs to the end of Phase 3 , possibly representing an entrance passage feature like Antenna 1 and Antenna 2 in Phase 1.

House 2, in the interior may be the only surviving trace of a house, or houses, of the three fortified phases. It was not, however, stratigraphically related to any other main element and it could, therefore, belong to any period of occupation on the promontory. Also in the interior, Palisade 0 cut House 1, and must belong to Phase 2 or later. The entrance in the palisade faces the main entrance 
route and it is likely that it was constructed while the features making the route, possibly Ditches 14, were still obvious. Palisade 0 may, therefore, predate Ditch 0 (Phase 4).

Houses 3 and 4 could belong to any period and could date from a period of open settlement before the construction of the Palisaded Homestead (Phase 1) to a period of open settlement later than the fortified periods. The position of the houses, however, on the line of the main entrance route, suggests that the houses do not belong to an active period of defence in Phase 3 . The two fourpost settings to the WSW of the houses may be associated with them and it is tempting to see each setting as belonging to a different house.

\section{The flanks}

The defences investigated on the flanks were all V-sectioned. Ditches 0 and 1 were not traceable on the upper east flanks, having been eroded away. Ditches 6 and 8, being shallower, probably suffered the same fate (if they ever existed on the flanks). It is likely, therefore, that the complex defence stratigraphy on the lower flanks represents Phase 3 activity only.

\section{ECONOMY AND ENVIRONMENT}

\section{Artefacts}

Jenny Shiels

Few of the artefacts retrieved from these excavations come from secure contexts and, as the sites lie on sands and gravels, non-anthropic transportation of material is likely to have been a factor in the deposition of the objects. Much of the material appears to belong to the late Bronze Age and Iron Age and with the exception of the Bronze Age battle-axe (45/67), a generally domestic function can be assigned to the assemblage. Of the stratified material, only a few sherds of coarse pottery (45/ $107,115,226,248,410$ and 460) and a smoothed sandstone slab (45/188) are directly associated with a domestic context, coming from House 1. Small, finer objects, including a spindle-whorl (45/ 2) and a piece of worked shale (45/17) from topsoil horizons, indicate that the more lightweight finds which may be expected to form part of a domestic Iron Age assemblage have been transported to the surface and are, therefore, attributable only within the broader context of the late Bronze Age and Iron Age.

Whilst the prehistoric material is found in a variety of contexts on both sites, the medieval material is, in the main, confined to topsoil horizons. This material consists almost entirely of pottery representative of the domestic wares of the 14th to 16th centuries and can be assigned to the known fabric types representative of this period in Scotland. Two iron nails and an iron strip may also belong to this period, but as these were also from topsoil contexts, and as the nails are badly corroded, their assignment to a particular typological group is not possible.

The other objects retrieved from these sites cover a broad span of archaeological periods and include a possible Mesolithic microlith (45/199), sherds from two Neolithic vessels $(45 / 579,580$, $586,587,588$ ) and a Bronze Age battle-axe dating to between the 17th and 13th centuries BC. Iron Age material includes two saddle-querns $(45 / 412,414)$ and pottery typically associated with late period hillforts $(94 / 126,155)$. One sherd of pottery is tentatively assigned to the Roman period (94/ 16) and a glass bead of the early Christian period dates to the seventh century. Medieval pottery, and possibly medieval metalwork, completes the wide range of artefacts which represents periodic activity on the sites over several millennia. 


\section{Macroplant remains}

\section{James S Rideout}

The value of the bulk sampling strategy is questionable, mostly because of the nature and security of the contexts involved. Discussion of the macroplant remains from the large number of miscellaneous pits and post-holes in the internal area is futile because they cannot be related to the main structural elements. Samples from the miscellaneous pits and post-holes investigated in the 1985 season were processed, but not assessed for this very reason. With the exception of the results from the plateau ditches, most of the rest of the material is of little use because of the nature of the contexts. As noted above, contexts like post-holes, palisades, ring-grooves and pits of unknown function contain material whose source is uncertain. Contexts like hearths (fire pits) and larger pits can produce more secure macroplant remains. Fire pit F35 produced a few seeds but the context cannot confidently be related to the house within which it sits. The large dated pit F36 also produced macroplant remains. It is interesting to note, however, that the seed types from F36, dated to the early medieval period, are substantially the same as those from supposedly early Iron Age contexts like House 1.

The limited sampling of Ditch 0 in 1982, and the more systematic ditch sampling in 1985, produced variable results. As might be expected, few seeds were recovered from most of the ditches. Only Ditch 0 and Ditch 3 produced a range of seed types from a number of layers. Ditch 0 produced a comparatively large number of cereal seeds, and various other seeds, as might be expected from the ditch closest to the internal, occupation area. Ditch 3 produced a smaller range of a fewer number of seeds. Cereal grains were present. It is unclear why the Ditch 3 samples contained so much more macroplant remains than the other ditches (Ditch 0 excepted).

Given the interpretation and dating of the main structural features, all that can be said about the results of the macroplant sampling is that they suggest that the economy of the site, throughout its occupation, was at least partly arable with barley, oats, and possibly wheat featuring in the diet. The other seeds identified are not unusual, given the topographical position of the site and the obviously large amount of anthropic activity.

\section{Pollen core}

The results of the assessment of the peat core from the bog to the east of the promontory, combined with the four radiocarbon dates, suggest that there was human activity in the area of the fort, if not on the fort itself, for a very long period.

Zone B2, seen as possibly indicating a long period of intermittent clearance or grazing at the site, and limited cultivation in the region, has a start date of (GU-1658) $7270 \pm 110 \mathrm{BP}$ and an end date (start of Zone B3) of (GU-1659) $3485 \pm 65$ BP. That there was activity in the area during the Neolithic is attested to by the presence of the pit and post enclosures to the south of the site. Zone B3 has an end date of (GU-1660) $1905 \pm 90$ BP and shows an increase in inwash of sands from upslope and continuous regional cultivation. The increased inwash of sands seems to have resulted from the active defensive period of the fort. Indeed, lenses of sand associated with this activity, on the east flank, were noted during the excavation to run into the bog. This might help to provide a date for the end of the defensive period as identified on the plateau to the beginning of the first millennium AD.

Zone B4 is seen as being the start of continuous clearance in the area with a maximum of cultivation at the beginning of Zone B5, dated to (GU-1661) $1350 \pm 55$ BP. Cultivation continues after this date, probably to the present day. To summarize, there has been agricultural activity of 
some sort in the area of the site from before the period represented by the main structural elements on the promontory through to the present. This does not contradict the suggested interpretation based on the structures in the area, the artefact evidence, and the macroplant material from the site.

\section{Faunal remains}

As with the other finds and samples, the bone (finds) from contexts like pits, post-holes and the smaller linear features were not securely stratified (see Table 14, fiche). With the possible exception of the material from Ditch 0 , the same is probably the case with the material from ditch fills. The two finds from Ditch 0 appear to belong to a period of occupation shortly after the ditch construction. It is likely, however, that most of the burnt bone derives from the occupation of Homestead 2 and fort phases and that during this period animal husbandry, of sheep, cattle and pigs, played a part in the economy of the site.

\section{DISCUSSION}

HOMESTEADS $1 \& 2$

The homesteads at Bannockburn, including the unexcavated Homestead 3, appear to have comprised single houses within single palisade trenches. Homesteads 1 and 3 had more or less circular enclosures with centrally located houses while Homestead 2, being situated on the nose of a promontory, was probably less regular in shape.

With radiocarbon dates only from Homestead 2, it is impossible to ascertain how the three homesteads relate to each other chronologically. While it is possible that all three were occupied at the same time, their proximity to each other would suggest that they are more likely to have been occupied at different periods. Each of the two excavated examples, however, appear to have been occupied for sufficient time to necessitate refurbishment and reconstruction. The palisades of both show evidence of partial refurbishment, while that of Homestead 1 may have been totally rebuilt on the original line. The replacement of a length of palisade at Homestead 2 is similar to the palisade at Glenachan Rig, Peeblesshire, where decay or destruction was suggested as the reason for partial refurbishment (Feachem 1959, 18-20) and to a 'replacement trench' at the south-west angle of the homestead at West Brandon, Durham (Jobey 1962, 6 \& 20).

The house in Homestead 1 was also rebuilt on a slightly different location. The size and solid construction of the later house in Homestead 1 and the even more solid construction of House 1 in Homestead 2 would suggest that, with care and attention, they could have continued in use for a long time. It is possible, however, that, at least in Homestead 1, the nature of the subsoil, combined with wear and tear, shortened the lifespan of the earlier house. Rebuilding of houses on more or less the same site is not uncommon in the Iron Age and is seen at Bannockburn in the replacement of House 3 with House 4, to the south of the defences of the fort. Replacement has also been identified at, among others, the homestead at Scotstarvit Covert in Fife (Bersu 1948, 250), the homestead at West Brandon (Jobey 1962, 13-16) and the settlement at Harehope, Peeblesshire (Feachem 1960, 179-80).

Although basically similar, there are some differences between the two excavated homesteads. While the houses are of similar dimensions, the wall of the later house at Homestead 1 was plankbuilt with overlapping split timbers, while House 1 in Homestead 2 appears to have been more substantial with closely spaced rounded timbers. The plank-walled house has a parallel at Dryburn Bridge, where House 2 had a wall of radially split oak uprights (Triscott 1982, 120). The arrangement 
of the planks in Homestead 1, overlapping with the rounded sides facing each other, would have created a weathertight wall requiring, perhaps, the application of clay to seal the joins. Clay sealing may also have been necessary in Homestead 2 where there must have been larger gaps between the uprights caused by irregularities in the timber used. At West Plean, $2.8 \mathrm{~km}$ to the SSW of the sites at Bannockburn, on the other hand, the timbers in the ring-groove were spaced fairly evenly at about $1 \mathrm{~m}$ apart. Here, the author suggested that they were uprights for a wattle-and-daub wall (Steer 1956, 233-4).

\section{THE HOUSES}

The ground plans of five houses can be identified or inferred at the two sites; two houses superimposed in Homestead 1, House 1 in Homestead 2, and the two superimposed houses, House 3 and House 4 in the entrance through the defences of the fort. It is clear that there are differences of scale involved (see Table 5). The houses in the homesteads are massive while Houses 3 and 4 are of a more common size (see, for instance, the graph showing proportional relationships in round-houses in Hill 1982b, 82, Fig 2).

TABLE 5

House dimensions (m)

House Inner ring

Wall-groove

Outer ring

Homestead 1, A

10.9

Homestead 1, B

10.4

Homestead 2, House 1

11.0

Fort, House 3

Fort, House 4

5.2

5.5

15.8

14.5

14.5

9.8

10.0
18.6

18.6

18.0

nil

nil

Table 5 gives the dimensions of the five houses. Several assumptions have been made. Although only less than half of the house in Homestead 1 was excavated, it has been assumed that the projected diameters are accurate. The shallower ring-groove is, possibly, the earlier and this is reflected in the numbering (House A). It is also assumed that the two post-holes out of line with the rest of the inner post-ring are part of a post-ring of greater diameter, largely destroyed, associated with the groove of House A. For the sake of completeness, the outer post-ring is seen as belonging to both houses. The outer post-ring at House 1, Homestead 2, is accepted as proven but the putative innermost ring is ignored. The diameter of the inner ring in House 3 is accepted.

Since there is only one almost complete ground plan for the larger houses and given that there is an element of doubt about the interpretation of the two houses in Homestead 1, it would probably be best to look in detail at House 1 in Homestead 2. If the main wall was, for instance, $2 \mathrm{~m}$ high and the roof pitch was $45^{\circ}$ (for a thatched roof) then the roof, if it continued outwards, would meet the ground at a line approximately $18 \mathrm{~m}$ from the centre of the house. This is unlikely to have been the case since this would coincide with the outer post-ring (unless the outer posts simply served as 'pegs' to which the rafters were attached). If the outer post-ring had acted as a sort of 'colonnade', therefore, either the roof-pitch was less than $45^{\circ}$ or the main wall was higher. If, for instance, the outer posts were $1 \mathrm{~m}$ high, and the roof pitch was $45^{\circ}$, the main wall would have been $2.7 \mathrm{~m}$ high and the inner post-ring $4.5 \mathrm{~m}$ high. Alternatively, if the outer ring was $2 \mathrm{~m}$ high, the main wall would have been $3.7 \mathrm{~m}$ high and the inner post-ring $5.5 \mathrm{~m}$.

This latter is similar in scale, although not in detail, to the reconstruction given by Reynolds for a ring-ditch house at Dryburn Bridge (1982, 52, Fig 5). Like the reconstruction, there is adequate 


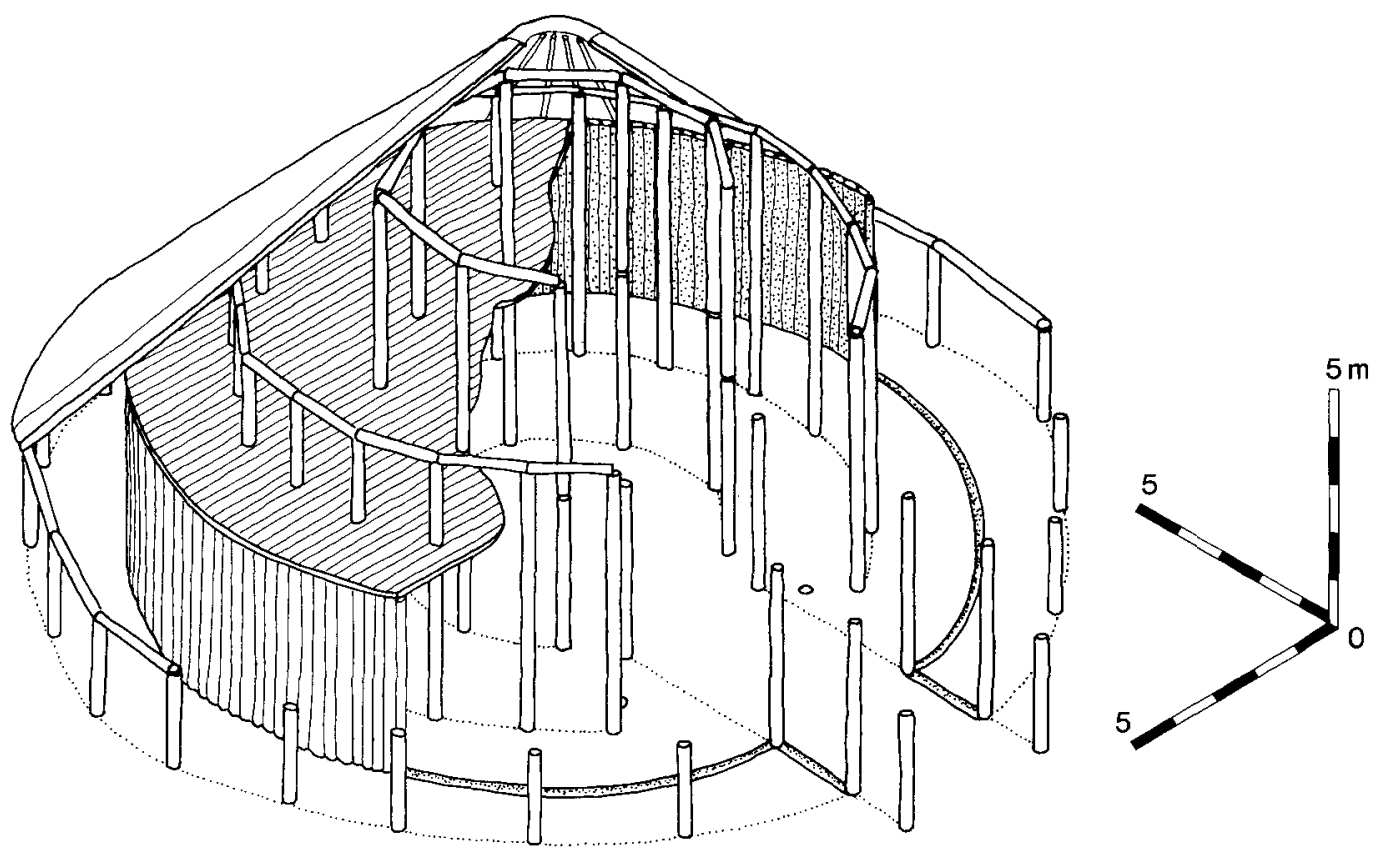

Illus 34 Isometric partial reconstruction of House 1 in Palisaded Homestead 2, from the south

room for an upper floor (the apex of the roof would be nearly $11 \mathrm{~m}$ above the ground). A floor at the level of the top of the outer wall would almost double the internal floor-space in the house. This would, however, necessitate a span of $11 \mathrm{~m}$ between supports if the inner post-ring was the main support for the floor. It is more likely, therefore, that there was an upper floor additionally supported by an innermost post-ring, possibly the $6 \mathrm{~m}$ diameter ring postulated in the description section above (see illus 34 - an isometric reconstruction showing the possible layout and relative scale of the various elements of Homestead 2, House 1 which assumes an outer post-ring height of $2 \mathrm{~m}$ and an innermost post-ring). An innermost post-ring of similar diameter would have been outwith the excavated area in Homestead 1. A similar feature, however, was found in House 1 in the palisaded settlement at High Knowes, Alnham, with an innermost 'ring' measuring c $7 \mathrm{~m}$ by c $5 \mathrm{~m}$ within a ring-groove c $14.6 \mathrm{~m}$ in diameter and an inner post-ring of c $11 \mathrm{~m}$ in diameter (Jobey \& Tait 1966, Fig 4). This is also a possibility in the round-house of similar size at Little Woodbury (House I, Bersu 1940, Fig 20). Here, within an inner ring of more than $11 \mathrm{~m}$ in diameter, there are four posts forming a square c $3 \mathrm{~m}$ on a side (this is probably better illustrated in Guilbert 1981, Fig 7, where the post-holes are highlighted with question marks). Little Woodbury House I also has another feature, a possible extended entrance passage, similar to Homestead 2, House 1. The Little Woodbury house has no obvious sign of an outer post-ring but does have a porch which extends beyond the outer wall, like F 24 and F25, and with two posts inside the line of the inner post-ring similar to F26 and F27 in House 1 above. The Little Woodbury House I doorway, like Homestead 2, House 1, was aligned with the entrance through the palisade (first phase at the site).

Round-houses of similar dimensions, but of different arrangements of detail include House II at Little Woodbury (Bersu 1940, Fig 27), Winklebury Camp 3890 (Smith 1977, Figs 5 \& 8) and Crickley Hill B1 (Dickson 1973, Fig 11). All are dated to around the middle of the first millennium 
BC. Of somewhat later date is a double-doored round-house, Building 1, at Rispain Camp, Wigtownshire, with a diameter of $13.5 \mathrm{~m}$ for the wall-groove and c $10.3 \mathrm{~m}$ for the inner post-ring (Haggarty \& Haggarty 1983, Fig 10). The closest parallel to the Homestead 2 house, however, is House B in the rectilinear homestead at West Brandon, Durham (Jobey 1962, Fig 5). This was interpreted as having an outer post-ring c $16.8 \mathrm{~m}$ in diameter in line with the outer ends of entrance porch grooves. The ring-groove was c $14.9 \mathrm{~m}$ in diameter and the inner post-ring c $8.4 \mathrm{~m}$. Within this were four postholes forming a square c $3.9 \mathrm{~m}$ on a side (ibid, 16-17). The house was placed in a phase of the homestead in which a bank and ditch had replaced a double palisade.

While the two superimposed houses in Homestead 1 are close parallels for House 1, the two houses in the entrance area of the fort are of a very different scale with the external diameters of House 3 and House 4 smaller than the inner post-ring of the large house. With a ring-groove $10 \mathrm{~m}$ in diameter, and with an assumed outer wall height of $2 \mathrm{~m}$ and roof pitch of $45^{\circ}$, the height of the roof at the apex would have been $7 \mathrm{~m}$ and the height of the post-ring $4.3 \mathrm{~m}$. House 3 would have been of similar dimensions.

\section{PROMONTORY FORT}

It is clear that, at some stage, Homestead 2 was replaced by a defensive fort. Unfortunately, there was no evidence to indicate whether or not there was continuity of occupation between the phases. Replacement of palisades by more defensive construction is seen as part of the Hownam Model although, in its original form, the earliest defensive style was typically thought to be a single stone wall (Piggott, C M 1948) rather than the bivallate earthworks at Bannockburn. Palisade replacement was also indicated at Hayhope Knowe, Roxburghshire, by an unfinished rampart and ditch (Piggott, C M 1949), at Braidwood, Midlothian, by two ditches and medial rampart (Piggott, S 1958, although see the alternative interpretation in Reynolds 1982, 46-7) and at Murton High Crags (Jobey \& Jobey 1987). Unlike the Bannockburn sites, both are identified as settlements rather than homesteads. Like Bannockburn fort, continuity of occupation was neither proved nor disproved.

The three main phases of earthwork construction on the promontory suggest a long period of defence, although it is possible that the unstable subsoil was a contributory factor, necessitating the recutting of ditches in active use, and the cutting of wholly new lines of defence after inactive periods. The intervals between the phases, long enough to allow substantial infilling of the ditches by natural forces, were of unknown length. The Phase 2 ditches (Ditch 6 and Ditch 8 ) appear to have infilled gradually although not necessarily over a long period of time. The Phase 3 ditches, less stable in design, probably had a rapid initial infill due to collapse of the ditch sides and rampart material, followed by a more gradual infilling. Again, although much refurbishment was noted in Phase 3, a long period of time is not necessarily indicated. However, the remains suggest that defences, or new defences, were deemed necessary or desirable by the occupants on at least three occasions, each on a slightly different line.

Complete reconstruction or major refurbishment may only be noticeable in forts in sand and gravel areas where the defences would rapidly lose their effectiveness. Few forts in such situations have been excavated in Scotland but this seems to have been the case in the more complex fort at Broxmouth, East Lothian (Hill 1982a, 147-50) and, nearer to Bannockburn, at the unexcavated fort at Wester Carmuirs, near Falkirk (Maxwell 1983, 251 Pl 3).

Phase 3 appears to represent the most intensive defensive period, with five or six ditches covering a spatial depth of about $65 \mathrm{~m}$ on the plateau. This would appear to be excessive given the size of the internal area, even allowing for heavy erosion having removed some of the nose of the promontory. In addition, most of the lines of the defence would have been impressive, and in the 
case of Ditch 5, massive. Similar large ditches were found at Camelon, $10 \mathrm{~km}$ to the SSE (and $1 \mathrm{~km}$ east of Wester Carmuirs), where a small area was defended by three large ditches and a palisade (Proudfoot 1978, 114-15). Like Bannockburn, Camelon is a lowland fort on a promontory in a sand/ gravel terraceedge.

Unfortunately, such sites are prone to heavy plough truncation and much of the detail of the defences, and occupation area, will have been lost. At Bannockburn, the heavy erosion on the upper east flank, at least, has affected the main entrance route and, as a result, presumed entrance or gateway details will have been lost. In addition, the more intense activity in the area of Ditch 8 and Ditch 1 has presumably removed inner gateway details. Even in the discrete features in the Ditch 0 entrance, no clear pattern could be discerned.

Plough truncation has also removed all traces of the ramparts which must have been associated with the ditches. The smaller negative features which have survived do not seem to be the remains of timber revetment. Although it is possible that some of the palisade trenches may have been bank revetment, as at Braidwood (Piggott S 1958, Fig 2) and Broxmouth (Hill 1982a, 163 Fig 6), their positions indicate that this is unlikely. Although Palisade 8 is superficially similar to the revetment trench at Braidwood or the Period V1 revetment at Broxmouth (op cit) it is difficult to imagine with which ditch it could be associated. Also superficially similar, Palisade 6 actually ran over the completely infilled Ditch 3, and therefore cannot be the same. Post Alignment 1, however, may represent a back revetment for a rampart between Ditch 3 and Ditch 4 . On the flanks the remains were more confused and on the lower flanks it is difficult to imagine anything other than a 'corrugated' effect of ditches with no ramparts, although possibly with timber elements on the crests like the probable light timber chevaux de frise on the west flank.

Given that the palisade trenches represent the remains of freestanding, and at least in the case of Palisade 3 and Palisade 4, substantial, palisades, it is obvious from the horizontal stratigraphy that such stockading is a recurrent feature at Bannockburn. Indeed, palisades appear to span a period starting possibly with Phase 1 homestead and continuing at least to the end of Phase 4 . While some may be stock control features of periods other than Phases 2 to 4, others like Palisade 3 and Palisade 4 appear to be similar to the earlier Palisade $1 / 2$ of Homestead 2. It is possible, therefore, that there were periods of 'palisaded homestead' between and after active defensive phases.

It is unfortunate that it was not possible to 'fine-tune' the dating of the defences. The evidence suggests only that there was an intensive period of activity involving three phases of ditch construction and, probably, periods of palisade building and other activity. Even rough dating of the defensive period is difficult. It is assumed that the radiocarbon date from House 1 provides a terminus post quem for the start of the defences and that the dated fire pit F30 belongs to one of the fort phases. While the uncalibrated House 1 date fits well with other dated palisaded sites, when it is calibrated (see Table 2) it is obvious that it falls into the 'disaster area' of the curve (see the graph in Stuiver \& Kra 1986), spanning 390 years at the two sigma level of confidence ( $790-400 \mathrm{BC}$ ). At two sigma, the calibrated F30 date spans 210 years $(400-180 \mathrm{BC})$ and does not overlap with the House 1 date. As a result, it is impossible to give a satisfactory start date for the defences.

An end date for the defences might be indicated by the dated start of Zone B4 in the peat profile, typified by heavy upslope activity, probably of the active Phase 3 period. This would be a terminus post quem for the end of the defensive period. Unfortunately, this date falls into another 'disaster area' in the curve and at two sigma spans 441 years (110 $\mathrm{BC}-\mathrm{AD} 331)$. Using this information, therefore, the defensive phase at Bannockburn can be assigned only to a period probably starting in the second half of the first millennium $B C$ to some time in the first half of the first millennium $A D$.

The artefact assemblage is also of little help in dating the defences, those from secure contexts in the ditches being of general Iron Age date. The assemblage is not dissimilar to the smaller one 
from the fort on Gillies Hill, $5 \mathrm{~km}$ to the WNW (Rideout 1992). Here, a small excavation on a fort defended by at least three stone revetted earthen ramparts produced three radiocarbon dates which, unfortunately, also fall into the mid first millennium BC 'disaster area'. The assemblage is also similar to that from the undated fort at Meikle Reive, $22 \mathrm{~km}$ to the south-west (Fairhurst 1956, 82-5 and Photo 10). Unlike Bannockburn, Gillies Hill and Meikle Reive are on prominent hilltops at $140 \mathrm{~m}$ and $220 \mathrm{~m}$ OD respectively. The fort at Camelon produced no artefacts from primary contexts. Those recovered were of Roman origin and dated to the late first/second century AD (Proudfoot 1978, 120), not unusual given that it was enclosed by the annexe to the north of the Camelon Roman fort. The 'native' site at Camelon was seen by the excavator as starting before the Roman occupation and continuing after it but with a total period of occupation of no great length of time.

Sites in the vicinity of Bannockburn which have produced artefacts of Roman origin include Castlehill Wood Dun, $7.5 \mathrm{~km}$ to the west (Feachem 1957), Leckie Broch, $13 \mathrm{~km}$ to the ENE (MacKie 1982), Buchlyvie Broch, $23 \mathrm{~km}$ to the east (Main 1978) and the homestead at Keir Hill, Gargunnock, $11.5 \mathrm{~km}$ to the ENE (MacLaren 1958). The dun and brochs appear to belong to the early first millennium $\mathrm{AD}$ and are some of a significant number of duns and brochs in lowland Scotland to the south and west of Bannockburn. It is unclear if forts were occupied at the same time as these intrusive sites but the conspicuous lack of Roman finds from Bannockburn (except for a single possible sherd) and Gillies Hill suggests that the forts were not occupied during the Roman interlude. It is possible, therefore, that a pre-Roman date for the end of the defensive period at Bannockburn should be considered.

Following the defensive period of the fort, activity on the promontory either declined or left few identifiable traces. The two houses, House 3 and House 4, could belong to this period but could equally well fit into an earlier, possibly pre-Phase 1 , period. It is even possible that the houses were in use during a hiatus between active defensive periods (eg at the end of Phase 2, when Ditch 6 and Ditch 8 were infilling and before the excavation of Ditch 1 to Ditch 5). Unenclosed round-houses with similar inner post-rings (and assumed wall lines) at Myrehead, West Lothian, were dated to the late second/ early first millennium BC (Barclay 1983, Figs 4, 5 \& 7) while other unenclosed houses of Iron Age date, albeit of somewhat larger construction, were found at Romancamp Gate, Moray (Barclay 1993, illus 3). Similar ring-groove houses at Broxmouth, East Lothian, were placed in pre-fort Period II (Hill 1982a, 148, 170-2).

Because of the rich and easily worked soils in the immediate vicinity, activity continued, probably at a fairly low level, until the present (the promontory, and the rest of the area to the west of the new road, is now under a modern housing estate).

Overall the activity in the area can be summarized as follows:

1 Mesolithic/Neolithic/Bronze Age activity as shown by the peat profile, the pit and post enclosures to the south, the possible Mesolithic microliths, the Neolithic pottery, the Bronze Age battleaxe and the dated timber from the bog.

2 Early Iron Age activity in the form of Homesteads 1-3.

3 Later Iron Age activity in the form of the promontory fort.

4 Post-fort activity as shown by the glass bead, Pit F36, the medieval and post-medieval pottery and rig andfurrow cultivation.

\section{POSTSCRIPT}

\section{James S Rideout}

This report was substantially written by the end of 1989, and work undertaken in 1995 merely involved tying up loose ends and editing the report for final submission to the Proceedings. In the 
process, however, the Discussion largely remained unchanged and, as rightly noted by others who have subsequently commented on the paper, new ideas raised in the intervening years were not addressed. In view of this, one welcomes the chance to update the Discussion, at the same time addressing niggling doubts about the function of the site.

Two factors are significant: the size and complexity of the large round-houses in Homestead 1 and the homestead phase of the fort $(\mathrm{H} 1)$; and, in the fort, the disproportionate size and complexity of the defences compared to the area enclosed (a problem also identified by Proudfoot: 1978, 1212). If House 2 in the fort is ignored (and its interpretation is less than certain), it is possible that House 1 continued in use for a considerable time, possibly throughout both palisaded and ditchdefended periods, or at least part of the defensive period. That a small area continued to be ditchdefended for long enough to include three main defensive phases with several refurbishments indicates that the house or any successors were of some importance.

While it is possible that both buildings were domestic structures, their size and apparently complex architecture hint at the possibility that they may have fulfilled a different function. It has been argued that two-story timber round-houses may have acted as byres (with animals stalled between the wall and inner post-ring on the ground floor) as well as for storage (in the central area of the ground floor and also the upper floor). This proposal has been developed at length by Diane Reynolds (1982, 52, fig 5) with reference to interpretative reconstructions of large ring ditch houses; Reynolds also noted the absence of hearths in these examples and suggested that such buildings would be unsuitable for ordinary domestic use. There were also no hearths at Bannockburn; however, no hollows or ring ditch features were identified, though these would easily have formed, as the subsoils were soft, especially at Homestead 1. It is possible, therefore, that the Bannockburn houses had neither domestic nor agricultural use (though grain storage in the upper floor, for example, would have left little or no trace in the archaeological record).

A review of the artefactual and ecofactual evidence from the site shows a distinct lack of significant material, especially material that could be assigned to the homestead period, although this is not unusual for Late Bronze Age and Iron Age sites in south and east Scotland (see, for instance, Cool 1982). Much of the material is relatively mundane and, as Shiels notes (above), none except the Bronze Age battle-axe would be out of place in a domestic context.

The existence of large domestic structures in south and east Scotland has been recognized for some time (for a review see Hingley 1992, 27-32). It is generally accepted that houses of this size may indicate 'high status and the isolation of the resident household from the broader community and from nature' (Hingley 1992, 39). The apparent continuity of this possible function at Bannockburn is mirrored at, for instance, Camelon (Proudfoot 1978) and in a slightly different form at Fairy Knowe, Buchlyvie, where a timber-built round-house was replaced on exactly the same site by a broch (Main 1978 and pers comm). It is obvious that at Bannockburn and Camelon, in the later stages, the number of large ditches and ramparts are, in functional terms, unnecessarily excessive. In purely defensive terms, only the innermost line could have been successfully defended against aggressors.

The depth of defences must, therefore, have been primarily for show - an elaboration of the impressive nature of the original house and enclosure. There was a lack of any complex gateway furniture in the Bannockburn fort (although erosion may account for this) and the long entrance-way in the multivallate phase could have acted as a stage for heroic challenges, corresponding to practices known in 'Celtic' warfare from ancient texts (Avery 1976, 48-50). This arrangement is somewhat similar to impressive but essentially non-defensive works like the northern blockhouses (Carter et al 1995, 473-7). This would imply that the single household, possibly an extended family or a family and its retainers, possibly all living in the 'big house', had some power and influence in the area. The presence of Homestead 1 and the unexcavated homestead further to the south-east could, therefore, be 
interpreted either as contemporary homesteads of equally powerful groups or families (their proximity to each other raising questions about land division) or as earlier sites of houses of the same family, moving progressively towards a more striking, more easily defended position.

Another possibility, however, is that for part of its life, the site had a wholly or primarily non-domestic, ritual/religious function. This need not preclude the existence of powerful families living in the buildings - indeed, the power of the families may have derived from, or have been reinforced by, religious/ritual duties and responsibilities, possibly involving a perceived importance of cattle (echoing Reynolds' comments: 1982, 53). Nor would this scenario preclude domestic activities resulting in disposal of the resulting refuse, although there is no indication at the site of deliberate ritual, or non-ritual, deposition. Neolithic ritual enclosures once existed less than $300 \mathrm{~m}$ to the south of Homestead 2 (Rideout forthcoming), which suggests some degree of continuity of use, for whatever reason, of this small area from the earlier Neolithic onwards (despite the gap in the record of structural remains in the vicinity, from the early third millennium BC until the early to mid-first millennium BC). Others have pointed to possible relationship of hillforts to earlier funerary and ritual monuments (Bradley 1981; Bowden \& McOmish 1987, 1989) and, although they refer to larger, southern British examples, it is also possible that ritual and religious activities may have played an important part in the siting, symbolism and use of smaller defended sites, especially in areas where larger fortified sites are the exception rather than the norm.

Much of the foregoing is little more than speculation. Hill (1989), however, rightly points out that the archaeology of the Iron Age has suffered from a 'domestication' of the record. This has led to Iron Age peoples being seen as simply earlier versions of recent agricultural populations. Whatever the customs of the people who made their mark on the prehistoric landscape at Bannockburn, it is unlikely to have been that of couthy farmers, tilling the land, looking after the stock and going to Kirk on Sundays.

\section{ACKNOWLEDGEMENTS}

The authors are grateful to the National Coal Board for permission to excavate, and to both local authorities (former Stirling District and Central Region), especially Lorna Main, the former Regional Archaeologist. Access from the west of the site was kindly provided by Mr Christie of Newpark Farm. Our thanks also go to Stirling Field Group for access to the records of the 1974 excavation.

Our greatest debt is to our excavation staff: Rosemary Cowie, Anne Crone, Anne-Marie Gibson, Rod McCullagh, V J McLellan and Chris Russell-White, and the volunteers, who worked so hard. The illustrations are by J S Rideout except the following: illus 28 and 31, find numbers $45 /$ $58,45 / 168$ and $60 / 26$ on illus 27 , find numbers $45 / 585$ and $94 / 132$ on illus 30 are all by Tanya O'Sullivan; illus 29, find numbers 45/579, 580,586 and 45/587, 588 on illus 27 and find numbers 45/67 and 45/2 on illus 30 are by Angie Townshend and illus 32 is by Emma Carter. Coralie Mills very kindly read and commented on the pollen assessment report. Alan Fairweather would also like to thank Camilla Dickson and Professor Boney for confirmation of identifications and to thank Dr D Habeshaw for the same and for advice.

The excavation, post-excavation processing and publication work was funded by Historic Scotland in its present and former incarnations.

\section{REFERENCES}

Avery, M 1976 'Hillforts of the British Isles; a student's introduction' in Harding, D W (ed) Hillforts: later prehistoric earthworks in Britain and Ireland, 1-58. London. 
Barclay, G 1983 'The excavation of a settlement of the later Bronze Age and Iron Age at Myrehead, Falkirk District', Glasgow Archaeol J, 10 (1983), 41-72.

Barclay, G J 1993 'The excavation of pit circles at Romancamp Gate, Fochabers, Moray, 1990', Proc Soc Antiq Scot, 123 (1993), 255-69.

Bersu, G 1940 'Excavations at Little Woodbury, Wiltshire. Part 1 : the settlement as revealed by excavation', Proc Prehist Soc, 6 (1940), 30-111.

Bersu, G 1948 “"Fort” at Scotstarvit Covert, Fife', Proc Soc Antiq Scot, 82 (1947-8), 241-63.

BGS 1969a Geological Survey of Great Britain (Scotland), Sheet 39, Stirling, Drift edn.

BGS 1969 b Geological Survey of Great Britain (Scotland), Sheet 39, Stirling, Solid edn.

Bowden, M \& McOmish, D 1987 'The required barrier', Scott Archaeol Rev, 4 (1987), 76-84.

Bowden, M \& McOmish, D 1989 'Little boxes: more about hillforts', Scott Archaeol Rev, 6 (1989), 12-16.

Bradley, R 1981 From ritual to romance: ceremonial enclosures and hill-forts', in G Guilbert (ed) Hill-Fort Studies - Essays for A H A Hogg, 20-7 Leicester.

Brooks, C L 1972 'Pollen analysis and the Main Buried Beach in the western part of the Forth Valley', Trans Inst Brit Geogr, 55 (1972), 161-70.

Brooks, C M 1980 'Medieval pottery from the kiln site at Colstoun, E Lothian', Proc Soc Antiq Scot, 110 (1978-80), 364-403.

Caldwell, D H \& Dean, V E 1981 'The post medieval pottery industry at Throsk, Stirlingshire', Scott Pottery Hist Rev, 6 (1981), 21-7.

Carter, S P, McCullagh, R P J \& MacSween, A 1995 'The Iron Age in Shetland: excavations at five sites threatened by coastal erosion', Proc Soc Antiq Scot, 125 (1995), 429-82.

Close-Brooks, J 1983 'Some early querns', Proc Soc Antiq Scot, 113 (1983), 282-9.

Clough, T H \& Cummins, W A 1979 Stone Axe Studies (= CBA Res Rep, 23.)

Cool, H E M 1982 'The Artefact Record: Some Possibilities', in Harding 1982, 92-100.

Darragh, R 1982 'Working unseasoned oak', in McGrail, S Woodworking Techniques before A.D. 1500. London. (= BAR Int Ser, 7.)

Dickson, P 1973 Crickley Hill. Fifth Report. Gloucester.

Durno, S E 1962 'Pollen Analysis of Peat', in Stewart, M E C 'The Excavation of Two Circular Enclosures at Dalnaglar, Perthshire', Proc Soc Antiq Scot, 95 (1961-2), 134-58.

Durno, S E 1976 in Birse, E L et al Plant Communities and Soils of the Lowland and Southern Upland Regions of Scotland. Macaulay Institute for Soil Research.

Eydt, R 1960 'A pollen diagram from a blanket bog in the Campsie Fells', Trans Bot Soc Edinb, 39 (1960), $28-34$.

Faegri, K \& Iverson, J 1975 Textbook of Pollen Analysis. Oxford.

Fairhurst, H 1956 'The Meikle Reive - A Hill Fort on the Campsies', Trans Glasgow Archaeol Soc, new ser XIV (1956), 64-89.

Feachem, R W 1957 'Castlehill Wood Dun, Stirlingshire', Proc Soc Antiq Scot, 90 (195-67), 24-51.

Feachem, R W 1959 'Glenachan Rig Homestead, Cardon, Peeblesshire', Proc Soc Antiq Scot, 92 (1958-9), $15-24$.

Feachem, R W 1960 'The Palisaded Settlements at Harehope, Peeblesshire. Excavations, 1960', Proc Soc Antiq Scot, 93 (1959-60), 174-91.

Grime, J P, Hodgson, J G \& Hunt, R 1988 Comparative Plant Ecology. London.

Guilbert, G 1981 'Double-ring roundhouses, probable and possible, in prehistoric Britain', Proc Prehist Soc, 47 (1981), 299-317

Guilbert, G 1982 'Post-Ring symmetry in Roundhouses at Moel Y Gaer and Some Other Sites in Prehistoric Britain', in Drury, P J (ed) Structural Reconstructions (= BAR Brit Ser, 110), 67-86. Oxford.

Haggarty, A \& Haggarty, G 1983 'Excavations at Rispain Camp, Whithorn, 1978-81', Trans Dumfriesshire Galloway Natur Hist Antiq Soc, 58 (1983), 21-51.

Haggarty, G R 1980 'The pottery', in Ewart, G 'Excavations at Stirling Castle 1977-78', Post-Medieval Archaeol, 14 (1980), 34-46. 
Haggarty, G R 1984 'Observations on the ceramic material from Phase I pits BY and AQ', in Tabraham, C J 'Excavations at Kelso Abbey', Proc Soc Antiq Scot, 114 (1984), 365-404.

Hall, D W forthcoming 'The pottery', in Hall, D W Excavations in the Medieval Burgh of St Andrews. Soc Antiq Scot Monogr in preparation.

Harding, D W (ed) 1982 Later Prehistoric Settlement in South East Scotland (=Univ Edinburgh Dept Archaeol Occas Pap, 8). Edinburgh.

Hill, J D 1989 'Re-thinking the Iron Age', Scott Archaeol Rev, 6 (1989), 16-24.

Hill, P H 1982a 'Broxmouth Hillfort Excavations, 197778: An Interim Report', in Harding 1982, 141-88.

Hill, P H 1982b 'A Sense of Proportion: A Contribution to the Study of Double-Ring Roundhouses', Scott Archaeol Rev, 1,1 (1982), 80-6.

Hingley, R 1992 'Society in Scotland from 700 BC to AD 200', Proc Soc Antiq Scot, 122 (1922), 7-53.

Holden, J H W 1976 in N W Simmonds (ed) Evolution of Crop Plants. London.

Holdsworth, P 1987 Excavations in the Medieval Burgh of Perth. Edinburgh. (= Soc Antiq Scot Monograph Ser, 5).

Jobey, I \& Jobey, G 1987 'Prehistoric, Romano-British and later remains on Murton High Crags, Northumberland', Archaeol Aeliana, 5 ser, 43 (1987), 151-98.

Jobey, G 1962 'An Iron Age homestead at West Brandon, Durham', Archaeol Aeliana, 4 ser, 40 (1962), 1-34.

Jobey, G \& Tait, J 1966 'Excavations on palisaded settlements and cairnfields at Alnham, Northumberland', Archaeol Aeliana, 4 ser, 43 (1966), 5-48.

Kemp, D D 1976 'Buried raised beaches on the northern side of the Forth valley, central Scotland', Scott Geogr Mag (1976), 120-8.

Lowe, J J 1982 'Three Flandrian pollen profiles from the Teith valley, Perthshire, Scotland', New Phytol, 81 (1982), 355-70.

MacAskill, N L 1987 'The pottery', in Holdsworth, P (ed) Excavations in the Medieval Burgh of Perth 19791981. Edinburgh. (= Soc Antiq Scot Monogr Ser, 5).

McCawley J C \& McKerrell 1972 'Soil phosphorus levels at archaeological sites', Proc Soc Antiq Scot, 104 (1971-2), 301-6.

MacKie, E W 1982 'The Leckie Broch, Stirlingshire: an interim report', Glasgow Archaeol J, 9 (1982), 60-72.

MacLaren, A 1958 'Excavations at Keir Hill, Gargunnock', Proc Soc Antiq Scot, 91 (1957-8), 78-83.

Main, L 1978 'Excavation at the Fairy Knowe, Buchlyvie, Stirlingshire 197578', Forth Naturalist \& Historian, 3 (1978), 99-111.

Maxwell, G S 1982 'Cropmark Categories Observed in Recent Aerial Reconnaissance in Scotland', Scott Archaeol Rev, 2, 1 (1982), 45-52.

Maxwell, G 1983 'Roman Settlement in Scotland', in Chapman, J C \& Mytum, H C (eds) 1983 Settlement in north Britain 1000 BC 1000 AD. Oxford. ( = BAR Brit Ser, 118), 233-62.

Murray, J C 1982 'The pottery' in Murray, J C (ed) Excavations in the Medieval Burgh of Aberdeen. Edinburgh. $(=$ Soc Antiq Scot Monogr Ser, 2), 116-76.

Pearson, G W \& Stuiver, M 1986 'Highprecision calibration of the radiocarbon time scale 500-2500 BC', in Stuiver, M \& Kra, R S 1986.

Piggott, C M 1948 'The Excavations at Hownam Rings, Roxburghshire, 1948', Proc Soc Antiq Scot, 82 (19478), 193-224.

Piggott, C M 1949 'The Iron Age Settlement at Hayhope Knowe, Roxburghshire : Excavations, 1949', Proc Soc Antiq Scot, 83 (1948-9), 45-67.

Piggott, S 1958 'Excavations at Braidwood Fort, Midlothian, and Craig's Quarry, Dirleton, East Lothian', Proc Soc Antiq Scot, 91 (1957-8), 61-77.

Proudfoot, E V W 1978 'Camelon Native Site', Proc Soc Antiq Scot, 109 (197-78), 112-28.

Reynolds, D M 1982 'Aspects of later prehistoric timber construction in southeast Scotland', in Harding 1982, 44-56.

Rideout, J S 1992 'Gillies Hill, Stirling, Central', in Rideout, J S, Owen, O A, \& Halpin, E 1992 Hillforts of southern Scotland. Edinburgh. (= AOC monog no 1). 
Rideout, J S forthcoming 'Excavation of Neolithic enclosures at Cowie Road, Bannockburn, Stirlingshire, 19845, Proc Soc Antiq Scot, 127 (1978).

Ritchie, P R 1968 'The stone implement trade in thirdmillennium Scotland', in Coles, J M Simpson, D D A (eds) Studies in Ancient Europe : Essays presented to Stuart Piggott. Leicester.

Roe, F E S 1966 'The battle-axe series in Britain', Proc Prehist Soc, 32 (1966), 119-245.

Roe, F E S 1979 'Typology of stone implements with shaftholes', in Clough, T H \& Cummins, W A 1979, $23-48$.

RCAHMS 1963 Royal Commission on the Ancient and Historical Monuments of Scotland Inventory of the Ancient and Historical Monuments of Stirlingshire. Edinburgh.

Schweingruber, F H 1978 Microscopic Wood Anatomy. Birmensdorf.

Soil Survey of Scotland 1968, Sheet 39 and part of Sheet 31.

Simpson, D D A 1969 'Excavations at Kaimes Hillfort, Midlothian, 1964-1968', Glasgow Archaeol J, 1 (1969), 728.

Sissons, J B 1966 'Relative sea-level changes between 10,300 and 8,300 in part of the Carse of Stirling', Trans Inst Brit Geogr, 39 (1966), 19-29.

Smith, A G \& Pilcher, J R 1973 'Radiocarbon dates and the vegetational history of the British Isles', New Phytol, 72 (1973), 903-14.

Smith, I 1979 'The chronology of British stone implements', in Clough, T H \& Cummins, W A 1979, 13-22.

Smith, K 1977 'The excavation of Winklebury camp, Basingstoke, Hampshire', Proc Prehist Soc, 43 (1977), $31-130$.

Steer, K A 1956 'The Early Iron Age Homestead at West Plean', Proc Soc Antiq Scot, 89 (1955-6), 227-51.

Stevenson, R B K 1949 'Braidwood Fort, Midlothian : The Exploration of Two Huts', Proc Soc Antiq Scot, 83 (1948-9), 1-11.

Stuiver, M \& Kra, R S (eds) Radiocarbon, 28, ( = Proc Twelfth Int Radiocarbon Conf, 24-8 June 1985, Trondheim, Norway), 839-62.

Tipping, R 1994 'The form and fate of Scotland's Woodlands', Proc Soc Antiq Scot, 124 (1994), 1-54.

Triscott, J 1982 'Excavations at Dryburn Bridge, East Lothian, 1978-1979', in Harding, D W 1982, 117-24.

Turner, J 1972 'A contribution to the history of forest clearance', Proc Roy Soc London B, 161 (1972), 343-54.

This paper is published with the aid of a grant from Historic Scotland 